\title{
INTERVALO ENTRE CORTES EM CAPIM-MARANDU (Brachiaria brizantha (Hochst. ex A. Rich.) Stapf cv. Marandu): PRODUÇÃO, VALOR NUTRITIVO E PERDAS ASSOCIADAS À FERMENTAÇÃO DA SILAGEM
}

\author{
LUCAS JOSÉ MARI
}

Dissertação apresentada à Escola Superior de Agricultura "Luiz de Queiroz", Universidade de São Paulo, para obtenção do título de Mestre em Agronomia, Área de Concentração: Ciência Animal e Pastagens.

PIR A C I C A B A

Estado de São Paulo - Brasil

Agosto - 2003 


\title{
INTERVALO ENTRE CORTES EM CAPIM-MARANDU (Brachiaria brizantha (Hochst. ex A. Rich.) Stapf cv. Marandu): PRODUÇÃO, VALOR NUTRITIVO E PERDAS ASSOCIADAS À FERMENTAÇÃO DA SILAGEM
}

\author{
LUCAS JOSÉ MARI \\ Médico Veterinário
}

\author{
Orientador: Prof. Dr. LUIZ GUSTAVO NUSSIO
}

\begin{abstract}
Dissertação apresentada à Escola Superior de Agricultura "Luiz de Queiroz", Universidade de São Paulo, para obtenção do título de Mestre em Agronomia, Área de Concentração: Ciência Animal e Pastagens.
\end{abstract}

\author{
P IR A C I C A B A \\ Estado de São Paulo - Brasil
}

Agosto - 2003 


\section{Dados Internacionais de Catalogação na Publicação (CIP) DIVISÃO DE BIBLIOTECA E DOCUMENTAÇÃO - ESALQ/USP}

Mari, Lucas José

Intervalo entre cortes em capim-marandu (Brachiaria brizantha (Hochts. ex A. Rich.)

Stapf cv. Marandu) : produção, valor nutritivo e perdas associadas à fermentação da silagem / Lucas José Mari. - - Piracicaba, 2003.

$138 \mathrm{p}$.

Dissertação (mestrado) - - Escola Superior de Agricultura Luiz de Queiroz, 2003. Bibliografia.

1. Capim marandu 2. Intervalo entre corte 3. Matéria seca 4. Produção 5. Silagem 6. Valor nutritivo I. Título

CDD 633.2

"Permitida a cópia total ou parcial deste documento, desde que citada a fonte - O autor" 
"Não é porque certas coisas são difíceis que nós não ousamos;

É justamente porque não ousamos que tais coisas são difíceis".

Sêneca (filósofo romano)

\section{Tocando em frente (Almir Sater \& Renato Teixeira)}

Ando devagar porque já tive pressa

E levo esse sorriso porque já chorei demais

Hoje me sinto mais forte, mais feliz, quem sabe

Eu só levo a certeza de que muito pouco eu sei

E nada sei

Conhecer as manhas e as manhãs, o sabor das massas e das maçãs

É preciso amor pra poder pulsar, é preciso paz pra poder sorrir

É preciso chuva para florir

Penso que cumprir a vida seja simplesmente

Compreender a marcha e ir tocando em frente

Como um velho boiadeiro levando a boiada

Eu vou tocando os dias pela longa estrada eu vou

Estrada eu sou

Todo mundo ama um dia, todo mundo chora

Um dia a gente chega, no outro vai embora

Cada um de nós compõe a sua história

E cada ser em si carrega o dom de ser capaz

De ser feliz... 
À minha querida e amada Melissa,

pelo carinho, incentivo, amor e paciência durante meu curso.

Aos meus amados pais, Marisa e José Antônio, pelos ensinamentos de dignidade, incentivo e amor.

Aos meus irmãos, Thiago e Débora, pelo amor oferecido.

\section{DEDICO}

Às minhas queridas avós, Zinha e Ruth, pelas preces e amor.

Ao meu primo e afilhado Vítor, pelas alegrias, sorrisos e amor. 


\section{AGRADECIMENTOS}

Ao Prof. Dr. Luiz Gustavo Nussio pela elaboração do projeto, orientação precisa, ensinamentos, amizade, exemplo de dedicação profissional e amor à pesquisa. Também à sua família: Carla, Vítor e Clara.

Aos meus pais, José Antônio e Marisa, pela orientação, dedicação e amor incondicionais; aos meus irmãos, Thiago e Débora, pelo amor e alegrias.

A todos os meus familiares, que sempre me incentivaram, avós, tios, tias, primos, primas etc, dos quais tenho muito orgulho, deixo meu agradecimento especial, com muito amor e carinho.

À minha querida e amada namorada Melissa Romano e seus familiares pelo convívio e alegrias.

Aos amigos do grupo de trabalho e pesquisa, André, Daniele, José Leonardo, Maity, Marta, Maurício, Patrick, Rodrigo e Solidete, sem a ajuda dos quais a realização deste trabalho seria impossível e por proporcionarem momentos de descontração.

Ao Prof. Dr. Wilson Mattos por me proporcionar inicial acolhida à Escola Superior de Agricultura "Luiz de Queiroz", pela contribuição ao trabalho final, exemplo de dedicação e de profissionalismo.

Aos professores do Departamento de Produção Animal, em especial aos professores Dr. Sila Carneiro da Silva e Dr. Carlos Pedreira pelas oportunas contribuições, ensinamentos, exemplos de dedicação e de profissionalismo.

À Escola Superior de Agricultura "Luiz de Queiroz", através do Departamento de Produção Animal pela oportunidade de realização deste trabalho. 
Ao funcionário do Laboratório de Bromatologia da USP/ESALQ Carlos César Alves e ao Dr. Fábio Campos pelas orientações, amizades e ajudas nas análises laboratoriais.

Ao funcionário exemplar José Marcos Arthuso (in memorian), Marcão, na pessoa de quem agradeço aos demais funcionários do Departamento de Produção Animal - Setor Ruminantes que foram fundamentais para a execução deste trabalho.

Aos amigos Adriano Beccari, Alessandro Campos, Alexandre Barreto, Bruno, Éder, Eduardo, Felipão, Fernando Borges, Leonardo, Max, Rodrigo Garcia, Thiago Romanelli e demais amigos de Uberlândia e Piracicaba, que sempre foram e serão importantes.

A todos colegas de curso, em especial aos amigos Daniel Sarmento, Fábio Maya, José Leonardo e Juliano Fernandes (Gomão) pela agradável companhia e troca de experiências durante o convívio.

À Universidade Federal de Uberlândia pela minha formação acadêmica e em especial ao amigo Prof. Dr. Edmundo Benedetti que me apresentou à pesquisa científica.

Aos "primos" e amigos de Portugal Camilo Leite e Ricardo Simões, que durante a estada contribuíram com o grupo de trabalho e pesquisa.

Aos estagiários do Clube de Práticas Zootécnicas (CPZ).

A todos que de maneira direta ou indireta contribuíram para a conclusão deste trabalho.

À FAPESP pela concessão da bolsa de estudo para a realização do curso, financiamento de parte do projeto e pelo exemplo de profissionalismo e seriedade para administrar os recursos a ela confiados.

E, sobretudo, a Deus, pela vida e por iluminar meu caminho. 


\section{SUMÁRIO}

Página

LISTA DE FIGURAS …..............................................................

LISTA DE TABELAS ................................................................... xiv

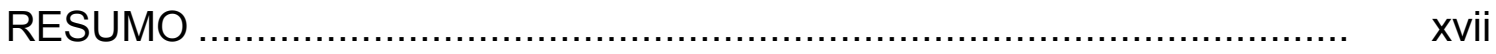

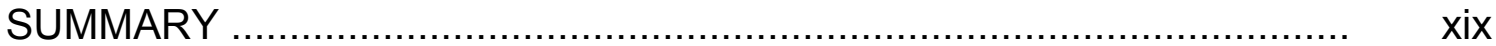

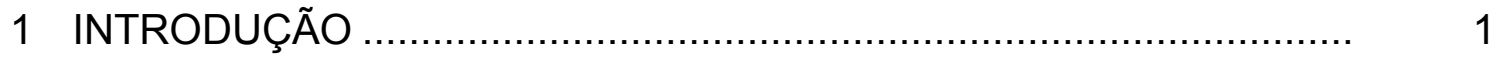

2 REVISÃO DE LITERATURA …..................................................... 4

2.1 Características da espécie ....................................................... 4

2.2 Produtividade, alterações morfológicas e de valor nutritivo associado à maturidade de plantas forrageiras ............................... 5

2.3 Silagem de capins tropicais e seu valor nutritivo .............................. 10

2.4 Tamanho de partículas, condutividade elétrica e atividade de

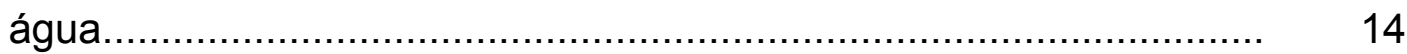

2.5 Perdas inerentes ao processo de ensilagem: efluentes e gases ....... 16

3 PRODUÇÃO, COMPOSIÇÃO MORFOLÓGICA E QUÍMICOBROMATOLÓGICA DO CAPIM-MARANDU, SUBMETIDO A INTERVALOS ENTRE CORTES ……………........................... 20

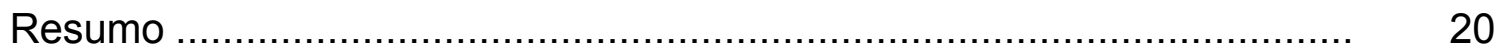

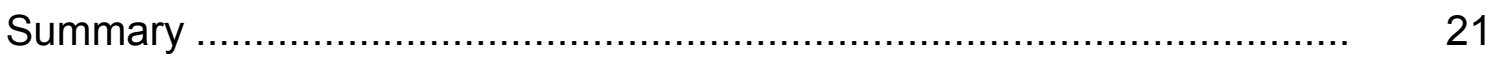

3.1 Introdução ................................................................. 22

3.2 Material e Métodos .................................................................... 24 


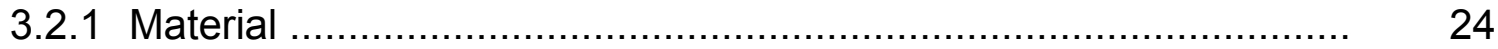

3.2.1.1 Espécie vegetal .............................................................. 24

3.2.1.2 Local do experimento ........................................................ 24

3.2.1.3 Solo da área experimental ............................................... 25

3.2.1.4 Implantação da área ........................................................ 25

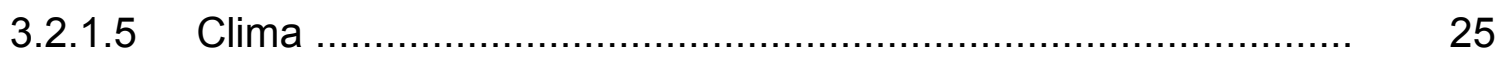

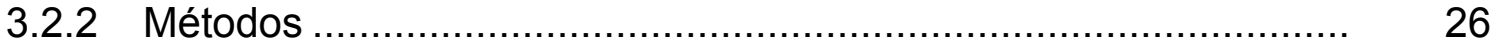

3.2.2.1 Delineamento experimental e tratamentos ............................. 26

3.2.2.2 Correção e adubação do solo ................................................ 28

3.2.2.3 Calibração: altura do prato x massa de forragem ..................... 29

3.2.2.4 Produção de matéria seca ................................................... 30

3.2.2.5 Coleta de amostras ...................................................... 30

3.2.2.5.1 Amostragem e amostras ................................................ 30

3.2.2.5.2 Determinação da composição químico-bromatológica das

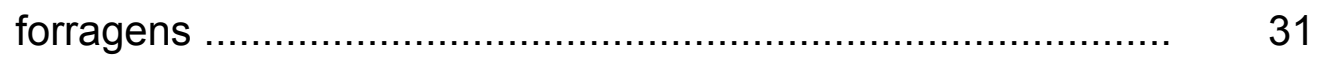

3.2.2.6 Análise estatística dos dados ............................................... 32

3.3 Resultados e Discussão ............................................................. 33

3.3.1 Produção de matéria seca .......................................................... 33

3.3.2 Composição morfológica da forragem ...................................... 38

3.3.2.1 Porcentagem de folhas ................................................. 38

3.3.2.2 Porcentagem de hastes ................................................. 40

3.3.2.3 Porcentagem de material morto .......................................... 42

3.3.2.4 Relação folha/haste ....................................................... 44

3.3.3 Composição químico-bromatológica da forragem ........................ 46

3.3.3.1 Teor de matéria seca da forragem ....................................... 46

3.3.3.2 Teor de proteína bruta da forragem .................................... 48

3.3.3.3 Teor de fibra insolúvel em detergente neutro da forragem ....... 50

3.3.3.4 Digestibilidade verdadeira in vitro da matéria seca da forragem ..................................................................... 53 
3.3.4 Produção de matéria seca digestível ......................................... 56

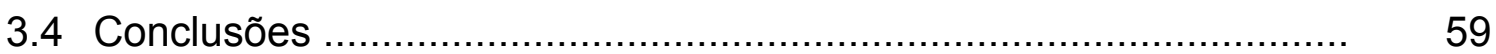

4 VALOR NUTRITIVO, ASPECTOS FÍSICOS E PERDAS ASSOCIADAS À FERMENTAÇÃO DE SILAGENS DE CAPIMMARANDU, CONFECCIONADAS COM FORRAGEM SUBMETIDA A INTERVALOS ENTRE CORTES …............................................ 60

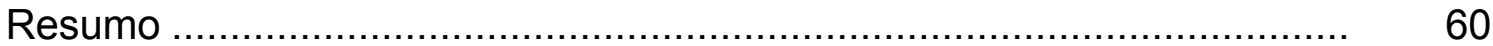

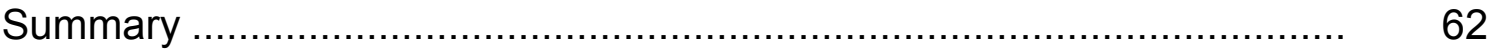

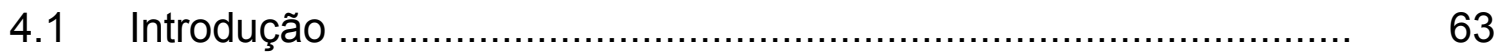

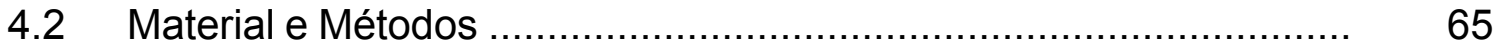

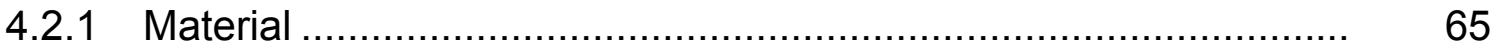

4.2.1.1 Espécie vegetal .............................................................. 65

4.2.1.2 Local e data do experimento …....................................... 65

4.2.1.3 Solo da área experimental .................................................... 65

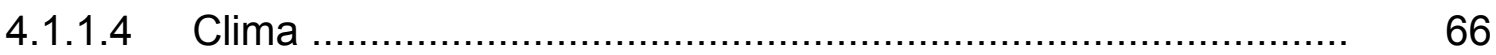

4.1.1.5 Forragem utilizada para a preparação das silagens ................ 66

4.1.1.6 Silos experimentais ....................................................... 69

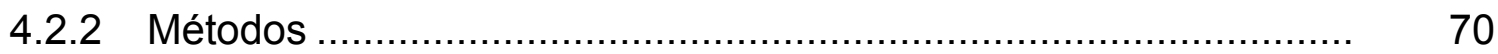

4.2.2.1 Delineamento experimental e tratamentos …......................... 70

4.2.2.2 Correção e adubação do solo ……….................................. 70

4.2.2.3 Colheita da forragem para enchimento dos silos experimentais 71

4.2.2.4 Enchimento dos silos experimentais ...................................... 72

4.2.2.5 Abertura dos silos experimentais …..................................... 72

4.2.2.6 Determinação das perdas por gases ...................................... 73

4.2.2.7 Determinação da produção de efluentes ................................ 73

4.2.2.8 Determinação da taxa de recuperação da matéria seca ........... 74

4.2.2.9 Coleta de amostras ............................................................ $\quad 75$

4.2.2.9.1 Amostragem e amostras .................................................. $\quad 75$

4.2.2.9.2 Determinação da atividade de água das silagens .................... 76 
4.2.2.9.3 Determinação da condutividade elétrica das silagens .............. 76

4.2.2.9.4 Determinação do tamanho de partícula das silagens .............. 76

4.2.2.9.5 Determinação do $\mathrm{pH}$ do extrato aquoso das silagens ............... 78

4.2.2.9.6 Determinação do teor de matéria seca das silagens ................ 79

4.2.2.9.7 Análise químico-bromatológica das silagens ......................... 79

4.2.2.10 Análise estatística dos dados .............................................. 79

$4.3 \quad$ Resultados e Discussão …................................................ 80

4.3.1 Composição químico-bromatológica das silagens ...................... 80

4.3.1.1 Teor de matéria seca das silagens .................................... 80

4.3.1.2 Teor de cinzas das silagens ............................................ 83

4.3.1.3 Teor de proteína bruta das silagens ..................................... 84

4.3.1.4 Teor de fibra insolúvel em detergente neutro das silagens ....... 85

4.3.1.5 Teor de fibra insolúvel em detergente ácido das silagens ........ 87

4.3.1.6 Teor de hemicelulose das silagens ........................................ 88

4.3.1.7 Teor de celulose das silagens ............................................ 89

4.3.1.8 Teor de lignina das silagens ............................................. 91

4.3.1.9 Digestibilidade verdadeira in vitro da matéria seca das silagens ................................................................. 92

4.3.1.10 Digestibilidade verdadeira in vitro da matéria orgânica das

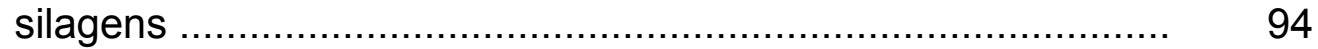

4.3.1.11 $\mathrm{pH}$ das silagens ........................................................ 95

4.3.2 Aspectos físicos das silagens ................................................... 96

4.3.2.1 Tamanho de partícula das silagens ....................................... 97

4.3.2.2 Densidade das silagens …............................................ 98

4.3.2.3 Condutividade elétrica das silagens ..................................... 102

4.3.2.4 Atividade de água das silagens .......................................... 105

4.3.2.5 Produção de efluente das silagens ........................................ 107

4.3.2.6 Perdas por gases das silagens ........................................... 110

4.3.2.7 Taxa de recuperação de matéria seca das silagens ................. 112 


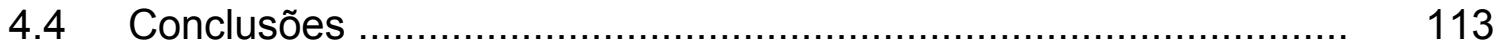

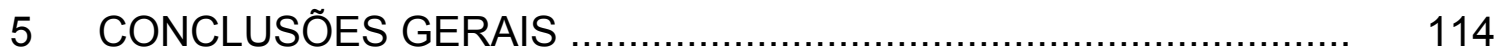

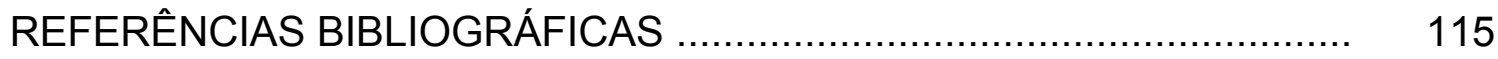




\section{LISTA DE FIGURAS}

Página

1 Estimativa da produção de efluente em relação ao teor de matéria

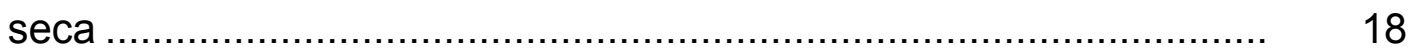

2 Vista aérea da área experimental ................................................. 27

3 Variação da relação folha/haste do capim-Marandu em função do intervalo entre cortes, nas estações do ano .....................................

4 Variação estacional dos teores de proteína bruta nos diferentes intervalos entre cortes em capim-Marandu ................................... $\quad 50$

5 Variação estacional dos teores de fibra insolúvel em detergente neutro nos diferentes intervalos entre cortes em capim-Marandu .....

6 Variação estacional dos coeficientes de digestibilidade verdadeira in vitro da matéria seca nos diferentes intervalos entre cortes em capim-Marandu

7 Produção acumulada de matéria seca, matéria seca digestível e coeficiente de digestibilidade verdadeira in vitro da matéria seca observadas para os intervalos entre cortes em capim-Marandu ........

8 Silo experimental com $20 \mathrm{~L}$ de capacidade, com válvula do tipo Bunsen adaptada para o escape de gases e dispositivo para a drenagem de efluentes

9 Detalhe da parcela experimental sendo cortada e colhida 
10 Detalhe do balde após a abertura para a quantificação do efluente produzido durante o processo fermentativo

11 Sistema Penn State Particle Size Separator com a adaptação da peneira superior (a) com perfurações de $38 \mathrm{~mm}$ e o sistema utilizado convencionalmente com as demais peneiras $(b, c, d)$.........

12 Proporção da massa retida em peneira de $38 \mathrm{~mm}$ de diâmetro, nas silagens de capim-Marandu ensiladas sob intervalo de cortes, nas estações do ano

13 Representação gráfica do tamanho de partículas (\% retida na peneira de $38 \mathrm{~mm}$ ) em função da densidade da massa verde das silagens de capim-Marandu confeccionadas no verão

14 Representação gráfica da distribuição da condutividade elétrica em função do tamanho de partículas (\% retida na peneira de $38 \mathrm{~mm}$ ) de silagens de capim-Marandu durante o verão e o inverno

15 Representação gráfica da produção de efluente em função do teor de matéria seca das silagens de capim-Marandu confeccionadas no verão e no inverno 


\section{LISTA DE TABELAS}

Página

1 Análise química do solo da área experimental ............................... 25

2 Radiação solar global média mensal, insolação diária média mensal, precipitação total mensal e temperaturas médias mensais durante o período experimental ..................................................... 26

3 Intervalo entre cortes planejado, intervalo efetivo médio, mínimo e máximo nos seis tratamentos estudados, durante os 352 dias de período experimental ...........................................................

4 Produção de matéria seca ( $\mathrm{t} \mathrm{ha}^{-1}$ ), por estação do ano, do capimMarandu submetido a intervalos entre cortes ................................. 34

5 Produção acumulada de matéria seca do capim-Marandu submetido a intervalos entre cortes, durante os 352 dias de período experimental .

6 Porcentagem média de folhas como componente da matéria seca do capim-Marandu submetido a intervalos entre cortes durante as estações do ano

7 Porcentagem média de hastes como componente da matéria seca do capim-Marandu submetido a intervalos entre cortes durante as estações do ano 
8 Porcentagem média de material morto como componente da matéria seca do capim-Marandu submetido a intervalos entre cortes

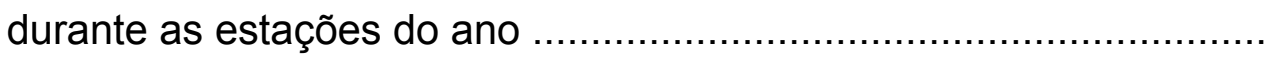

9 Relação folha/haste média do capim-Marandu submetido a intervalos entre cortes durante as estações do ano ..........................

10 Teor médio de matéria seca (\%) do capim-Marandu submetido a

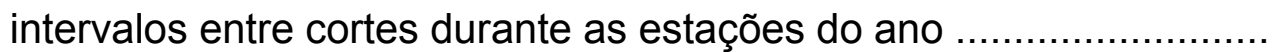

11 Teor médio de proteína bruta (\% MS) do capim-Marandu submetido a intervalos entre cortes durante as estações do ano

12 Teor médio de fibra insolúvel em detergente neutro (\% MS) do capim-Marandu submetido a intervalos entre cortes durante as estações do ano

13 Digestibilidade verdadeira in vitro da matéria seca (\%) do capimMarandu submetido a intervalos entre cortes durante as estações do ano

14 Produção acumulada de matéria seca digestível do capim-Marandu submetido a intervalos entre cortes, durante os 352 dias de período experimental

15 Teores de matéria seca, cinzas, extrato etéreo, fibra insolúvel em detergente neutro, fibra insolúvel em detergente ácido, hemicelulose, celulose e lignina da massa de forragem de capimMarandu colhida para ensilagem nos intervalos entre cortes, nas duas estações

16 Teores de proteína bruta, nitrogênio ligado à fibra insolúvel ao detergente ácido, nitrogênio ligado à fibra insolúvel ao detergente neutro, fração B3, digestibilidade verdadeira in vitro da matéria seca e digestibilidade verdadeira in vitro da matéria orgânica da massa de forragem de capim-Marandu colhida para ensilagem nos intervalos entre cortes, nas duas estações 
17 Retenção percentual de partículas de capim-Marandu, durante o corte de verão, submetido a intervalo entre cortes, utilizando-se o método Penn State Particle Size Separator convencional e adaptado com quatro peneiras

18 Teores de matéria seca, cinzas e proteína bruta das silagens de capim-Marandu, submetido a intervalos entre cortes, em duas estações do ano, verão e inverno

19 Teores de fibra insolúvel em detergente neutro e fibra insolúvel em detergente ácido das silagens de capim-Marandu, submetidos a intervalo entre cortes, em duas estações do ano, verão e inverno ....

20 Teores de hemicelulose, celulose e lignina das silagens de capimMarandu, submetido a intervalos entre cortes, em duas estações do ano, verão e inverno

21 Digestibilidade verdadeira in vitro da matéria seca, digestibilidade verdadeira in vitro da matéria orgânica e pH das silagens de capimMarandu, submetido a intervalos entre cortes, em duas estações do ano, verão e inverno

22 Densidade da matéria verde, da matéria seca e tamanho médio das partículas das silagens de capim-Marandu, submetido a intervalos entre cortes, em duas estações do ano, verão e inverno

23 Condutividade elétrica e atividade de água das silagens de capimMarandu, submetido a intervalo entre cortes, em duas estações do ano, verão e inverno

24 Produção de efluente, perdas por gases e recuperação de matéria seca das silagens de capim-Marandu, submetido a intervalo entre cortes, em duas estações do ano, verão e inverno 


\title{
INTERVALO ENTRE CORTES EM CAPIM-MARANDU (Brachiaria brizantha (Hochst. ex A. Rich.) Stapf cv. Marandu): PRODUÇÃO, VALOR NUTRITIVO E PERDAS ASSOCIADAS À FERMENTAÇÃO DA SILAGEM
}

\author{
Autor: LUCAS JOSÉ MARI \\ Orientador: Prof. Dr. LUIZ GUSTAVO NUSSIO
}

\section{RESUMO}

Os objetivos do estudo foram avaliar os efeitos do intervalo entre cortes e da estação do ano, sobre a produção de matéria seca (MS), composição morfológica e químico-bromatológica do capim-Marandu. Os tratamentos consistiram em seis intervalos entre cortes (T15, T30, T45, T60 T75 e T90), com forragens colhidas, respectivamente, aos 15, 30, 45, 60, 75 e 90 dias de rebrotação, conduzidos ao longo de 12 meses. Parte da forragem colhida foi ensilada em janeiro (verão) e julho (inverno), exceto T75. Foram realizados dois ensaios, no primeiro houve a caracterização da produção de MS, composição morfológica e químico-bromatológica da forragem. Num segundo ensaio foi caracterizada a composição químico-bromatológica das silagens de capimMarandu e foram avaliados alguns parâmetros físicos das mesmas, como densidade da massa verde (DMV), da massa seca (DMS), tamanho médio das partículas, condutividade elétrica (CE) e atividade de água $(A w)$. O processo fermentativo foi avaliado indiretamente através da quantificação das perdas por 
gases, produção de efluente e taxa de recuperação de MS das silagens. O delineamento experimental constituiu-se de blocos completos casualizados avaliando seis tratamentos para o primeiro ensaio e cinco no segundo. Para o ensaio de produção e qualidade da forragem os dados foram agrupados em ciclos de cortes de 90 dias para efeito de comparação entre os tratamentos. As produções de MS nos tratamentos T30 e T45 (21 t ha ${ }^{-1}$ ano $\left.^{-1}\right)$ foram inferiores $(\mathrm{P}<0,01)$ aos demais $\left(27 \mathrm{t} \mathrm{ha}^{-1}\right.$ ano $\left.^{-1}\right)$ e a produção de MS digestível $\left(16,2 \mathrm{t} \mathrm{ha}{ }^{-1}\right.$ ano-1) seguiu a mesma tendência. As alterações encontradas nas variáveis estudadas foram, sobretudo, decorrentes das variações ambientais, que levaram a alterações na composição morfológica e químico-bromatológica. Em geral, maiores intervalos entre cortes proporcionaram redução na porcentagem de folhas e aumento na de hastes que, como conseqüência, levaram ao declínio nos teores de proteína bruta (PB) e na digestibilidade verdadeira in vitro da matéria seca (DVIVMS), além de aumentos nos teores de fibra em detergente neutro (FDN). A silagem de inverno promoveu discreta alteração na composição químico-bromatológica entre os tratamentos, restringindo-se a variações nos teores de PB, FDN e celulose que levaram a alterações na DVIVMS. Na silagem de verão observou-se consistência de redução do valor nutritivo com a maior extensão do intervalo entre cortes da forragem ensilada, com aumento das frações da parede celular, exceto hemicelulose, e diminuição nos componentes do conteúdo celular. Os valores de $\mathrm{pH}(4,9)$, apesar de elevados, estiveram dentro da amplitude de variação esperada para silagens de capins tropicais. O menor tamanho de partículas $(31 \mathrm{~mm})$ proporcionou maiores $(P<0,01)$ DMV $\left(633 \mathrm{~kg} \mathrm{~m}^{-3}\right)$. Os maiores teores de MS nas silagens confeccionadas no inverno levaram a maiores perdas por gases e menores produções de efluente, com maiores taxas de recuperação de MS. A otimização do intervalo entre cortes, visando conciliar elevada produção de MS e valor nutritivo satisfatório, ocorreu ao redor dos 60 dias de crescimento vegetativo, quando a baixa digestibilidade $(63,1 \%)$ foi compensada pela maior produção de MS (27 t ha ${ }^{-1}$ ano $\left.^{-1}\right)$ e menores perdas $(3,45 \% \mathrm{MS})$ no processo fermentativo. 


\title{
CUTTING INTERVALS IN MARANDU GRASS (Brachiaria brizantha (Hochst. ex A. Rich.) Stapf cv. Marandu): DRY MATTER YIELD, NUTRITIVE VALUE AND SILAGE FERMENTATION LOSSES
}

\author{
Author: LUCAS JOSÉ MARI \\ Adviser: Prof. Dr. LUIZ GUSTAVO NUSSIO
}

\section{SUMMARY}

The objectives of this study were to evaluate cutting intervals and season of the year on dry matter (DM) yield, morphological and chemical composition of Marandu grass. Treatments consisted of Marandu grass harvested at 15, 30, 45, 60, 75 and 90-d intervals and was carried out during 12 months. Part of the harvested forage was ensiled, both in the summer (January) and in the winter (July) cuts, except that of 75-d interval. In the first trial was evaluated the dry matter (DM) yield, morphological composition and nutritive value of Marandu grass. In the second trial, silage samples were submitted to chemical and physical analysis (electrical conductivity - EC, water activity - Aw, particle size PS, fresh matter density - FMD, dry matter density - DMD, effluent yield, gases losses and dry matter recovery rate-DMRR). Randomized blocks with six treatments in the first trial and five treatments in the second one was the experimental design chosen. In the first trial data were pooled in 90-d interval to compare treatments. DM yield was lower $(P<0.01)$ at 30 and $45-d$ interval $(21 \mathrm{t}$ 
ha $^{-1}$ year $\left.^{-1}\right)$ as compared to $15,60,75$ and 90-d interval $\left(27 \mathrm{t} \mathrm{ha}^{-1}\right.$ year $\left.^{-1}\right)$. Digestible DM yield (16.2 $\mathrm{t} \mathrm{ha}^{-1}$ year $^{-1}$ ) followed the same pattern. Values observed in the measured parameters were probably due to environmental conditions, leading to morphological and chemical composition changes. In general, samples harvested at longer cutting intervals showed a decrease in leaves, crude protein (CP) content and in vitro true DM digestibility (IVTDMD) and an increase in stems and neutral detergent fiber (NDF) content. Among treatments, the winter cut silages showed minor chemical composition changes as compared to the summer cut silages. The summer cut silages showed a trend for increasing cell wall fractions, except hemicellulose and decreasing cell soluble contents as the cutting intervals were increased. Average silage $\mathrm{pH}$ values were 4.9. Small particle size $(31 \mathrm{~mm})$ silages had higher $(P<0.01)$ FMD $\left(633 \mathrm{~kg} \mathrm{~m}^{-3}\right.$ ). The higher DM content observed in the winter cut silages led to increased gases losses and DMRR and lower effluent yield. The 60-d cutting interval is recommended based on productivity $\left(27 \mathrm{t} \mathrm{ha}^{-1}\right.$ year $\left.{ }^{-1}\right)$, digestibility $(63.1 \%)$ and fermentation losses (3.4\% DM) values. 


\section{INTRODUÇÃO}

O Brasil apresenta características climáticas que favorecem a exploração de forragens com elevado potencial de produção de biomassa. As áreas de pastagem do nosso país compreendem, segundo dados da Food and Agriculture Organization - FAO (2003), aproximadamente 180 milhões de hectares, isto é, cerca de $20 \%$ do território nacional é ocupado por plantas forrageiras. Além da importância territorial, cerca de $90 \%$ dos bovinos têm sua exploração produtiva apoiada em pastagens.

Ocorre ainda, no Brasil, assim como nos outros países do trópico Sul, uma marcante estacionalidade da produção de forragens, sendo esse o principal fator de restrição na exploração da produção pecuária nacional. Ocorrem, durante o ano, períodos cíclicos de alta e baixa produção de forragem, característica das gramíneas de clima tropical, que conflita com o benefício do alto potencial de produção de matéria seca por área.

Durante a época chuvosa (outubro a março), devido à elevada disponibilidade de forragem e seu bom valor nutritivo, observa-se desempenho animal satisfatório. No entanto, na época de estiagem (abril a setembro), ocorre acentuada redução na produção das pastagens, determinando perda de peso dos animais e/ou drástica redução na produção de leite.

Para amenizar esse problema busca-se o manejo integrado da pastagem, que visa conservar o excedente de forragem da estação de produção a fim desse ser utilizado, estrategicamente, no período da seca. Os processos de fenação e/ou ensilagem são práticas convencionalmente 
utilizadas de conservação de forragem, sendo a produtividade e o valor nutritivo da forragem aspectos importantes a serem considerados quando da utilização dessas práticas de conservação em vista dos custos operacionais dos processos.

Visando oferecer alternativas às culturas anuais convencionais (milho e sorgo) e, sobretudo, associado ao manejo do pastejo, em 1935 foram iniciados trabalhos com a ensilagem de gramíneas tropicais, que, entretanto, somente foram intensificados na década de 70 , em especial com o capim-elefante (Pennisetum purpureum Schum. cv. Napier). Após esse primeiro momento de incentivo da utilização de silagens de gramíneas tropicais, houve certo desinteresse dessa técnica devido, provavelmente, à falta de equipamentos apropriados para o processo de conservação dessas forragens na forma de silagem. Na última década as empresas nacionais passaram a desenvolver e produzir os equipamentos capazes de picar a forragem colhida de forma mais eficiente, gerando novo estímulo a essa prática.

No estádio fisiológico ideal para o corte, devido às características intrínsecas das plantas forrageiras como a alto teor de umidade e os baixos teores de carboidratos solúveis, tem havido o questionamento sobre as perdas de valor nutritivo e de matéria seca durante o processo de conservação.

Dentre as espécies forrageiras existentes, as do gênero Brachiaria apresentam destacada participação no mercado brasileiro, adaptando-se às variadas condições de clima e solo. Porém sua extensa utilização deve-se, principalmente, à sua adaptação às condições de solos com baixa e média fertilidade. Apesar da destacada representação da braquiária decumbens (Brachiaria decumbens Stapf. cv. Basilisk) dentre as espécies do gênero, essas gramíneas vêm apresentando declínio da produção após ciclos de pastejo. A partir da década de 80, foi introduzido pela Empresa Brasileira de Pesquisa Agropecuária (EMBRAPA) o capim-Marandu (Brachiaria brizantha (Hochst. ex A. Rich.) Stapf. cv. Marandu), passando a ser largamente utilizado em pastejo 
e, mais recentemente, tem sido despertado o interesse no seu uso para os processos de conservação.

O presente trabalho teve como objetivos: estudar os efeitos do intervalo entre cortes e da estação do ano, sobre a produção de matéria seca, composição morfológica e químico-bromatológica do capim-Marandu visando a utilização dessa gramínea em um sistema de produção de silagem. Os resultados obtidos foram divulgados na forma de dois artigos científicos que constituem os capítulos 3 e 4 desta dissertação. 


\section{REVISÃO DE LITERATURA}

\subsection{Características da espécie}

A espécie é originária do Zimbabwe, África, uma região vulcânica onde os solos apresentam bons níveis de fertilidade (Bogdan, 1977), sendo que o cultivar Marandu, lançado em 1984 pela EMBRAPA-CNPGC, teve sua origem em germoplasmas introduzidos na região de Ibirarema em São Paulo (Nunes et al., 1985 e Skerman \& Riveros, 1990).

É uma gramínea perene, de grande produtividade, boas respostas à aplicação de fertilizantes, tolerância à seca, boa capacidade de se desenvolver em condições de sombreamento e produzir uma forragem de valor nutritivo satisfatório, apresenta boa tolerância ao frio, permanecendo verde no inverno. Como atributos negativos podem ser mencionados: a sua intolerância a solos com drenagem deficiente e a necessidade de moderada fertilidade para seu desenvolvimento (Bogdan, 1977 e Skerman \& Riveros, 1990).

De acordo com Nunes et al. (1985) é uma espécie forrageira cespitosa, muito robusta, de 1,5 a $2,5 \mathrm{~m}$ de altura, com colmos iniciais prostrados, mas que produz perfilhos predominantemente eretos. Possui rizomas curtos e encurvados. Colmos floríferos eretos, freqüentemente com perfilhamento nos nós superiores, o que leva à proliferação de inflorescências, especialmente quando a comunidade de plantas é submetida a regimes de corte e pastejo, segundo Da Silva (1995), essa espécie possui boa relação folha/haste. 
Outra característica favorável do capim-Marandu é sua tolerância à cigarrinha-das-pastagens (Botrel et al., 1998), além de que, quando utilizada sob pastejo, apresenta menor incidência de fotossensibilização em animais, característica de outras espécies do gênero (Valle et al., 2000),

\subsection{Produtividade, alterações morfológicas e de valor nutritivo associado à maturidade de plantas forrageiras}

Segundo Lavezzo et al. (1980), a identificação das modificações quantitativas, qualitativas e morfológicas das plantas forrageiras é de extrema importância para equacionar os problemas referentes à exploração das mesmas, e, de acordo com Langer (1959), o desconhecimento de tais modificações, implicaria em manejos empíricos inadequados.

Segundo Corsi (1990), a época de colheita da forragem, quer seja pelo corte ou pastejo, deve estar relacionada ao estádio de desenvolvimento da forragem, conseqüentemente, ao seu valor nutritivo. Colheitas de forragens mais maduras implicam na obtenção de um alimento com baixa proporção de carboidratos solúveis e de baixa digestibilidade devido ao decréscimo da relação folha/haste, que parece ser o principal fator de perda de qualidade da forragem com a maturação. A maioria das espécies forrageiras sofre declínio no seu valor nutritivo com o aumento da idade, resultado da menor relação folha/haste combinada com a crescente lignificação da parede celular. Contudo, o valor nutritivo pode ser controlado através do manejo adequado do pastejo e do momento do corte da forragem para conservação (Hoveland \& Monson, 1994).

Zago \& Gomide (1982) citaram que, dentro do manejo, merece destaque o intervalo entre cortes observando-se, em geral, a magnitude da variação da produção de massa de forragem com a extensão do intervalo entre cortes. Vários autores relataram como o intervalo entre cortes alterou de maneira 
antagônica a produtividade e o valor nutritivo da forragem (Andrade \& Gomide, 1971; Próspero, 1972; Silveira et al., 1973a e Zago \& Gomide, 1982). A redução da produtividade, segundo Brown \& Blaser (1965) e Ward \& Blaser (1961), ocorre devido ao esgotamento dos estoques de reservas orgânicas da planta forrageira comprometendo as sucessivas rebrotações. De modo geral, existe uma relação bem estabelecida entre um menor intervalo entre cortes e produção de massa seca por área, como observado por Acunha \& Coelho (1997); Alvim et al. (1999); Costa et al. (1992); Drudi \& Favoretto (1987); Gomide et al. (1985); Hassan et al. (1990); Narciso Sobrinho et al. (1998a); Ruggieri et al. (1995); Singh (1995); Vilela et al. (1978) e Zago \& Gomide (1982).

Em dados obtidos por Drudi \& Favoretto (1987), o capim-andropógon (Andropogon gayanus Kunth var. Bisquamulatus Hack.) apresentou maior produção de matéria seca (MS) aos 42 dias de intervalo de cortes (20 t ha ${ }^{-1}$ ), quando comparada com a produção aos 35 dias de intervalo de cortes (15 t ha $\left.^{-1}\right)$, em quatro cortes, durante cinco meses. Acunha \& Coelho (1997) também demonstraram esse efeito em capim-elefante, e obtiveram produções de massa seca entre 1210 e $8267 \mathrm{~kg} \mathrm{ha}^{-1}$, durante cinco meses de chuva, quando o intervalo de cortes variou entre 28 e 140 dias.

Alterações sazonais nas condições ambientais promovem variações na produção e na composição da forragem. As produções de matéria seca de capim-Marandu, quando amostradas aos 35 dias, em corte único em cada estação do ano, variaram entre 3,76 $\mathrm{t} \mathrm{ha}^{-1}$ na primavera, $2,03 \mathrm{t} \mathrm{ha}^{-1}$ no verão, 1,19 $\mathrm{t} \mathrm{ha}^{-1}$ no outono e $0,95 \mathrm{t} \mathrm{ha}^{-1}$ no inverno (Gerdes et al., 2000a).

As maiores mudanças que ocorrem na composição química das plantas forrageiras são aquelas decorrentes de sua maturidade (Balsalobre et al., 2001). Para Euclides et al. (1995), à medida que a planta forrageira amadurece, a produção dos componentes potencialmente digestíveis (carboidratos solúveis, proteína etc.) tende a decrescer, a proporção de lignina, celulose, hemicelulose 
e outra frações indigestíveis (cutina, sílica etc.) aumentam, diminuindo a digestibilidade.

Para Reis \& Rodrigues (1993), o estádio de desenvolvimento da forragem apresenta ampla relação com a composição química e digestibilidade das forragens. Mott (1970) definiu que valor nutritivo refere-se à composição química da forragem e sua digestibilidade e a qualidade de uma forragem é representada pela associação de sua composição bromatológica, digestibilidade e pelo consumo voluntário da forragem em questão.

O efeito da exposição da comunidade de plantas a intervalo entre cortes pôde ser comprovado pelos relatos de Lavezzo et al. (1980), que encontraram um aumento no teor de MS em $B$. decumbens de $18,5 \%$ para $33,4 \%$ quando o período se estendeu de 28 a 168 dias, respectivamente. Vieira \& Gomide (1970) também obtiveram teores médios de MS de 18,4\%, 22,0\% e 27,5\% quando o intervalo entre cortes em capim-elefante de evoluiu entre 28, 56 e 84 dias, respectivamente.

Existem relatos de que o aumento no teor de MS, a redução no teor de proteína bruta $(\mathrm{PB})$ e o aumento do teor de fibra bruta (FB), à medida que a planta tende a completar seu ciclo fisiológico, é fenômeno comum a todas as espécies forrageiras (Grieve \& Osbourn, 1965 e Rocha, 1979).

Embora tenha sido sugerido por Wilson et al. (1986), que o avanço da maturidade normalmente leva a um maior acúmulo de constituintes da parede celular, Ruggieri et al. (1995), não verificaram alterações nos valores de FB em maiores intervalos entre cortes. Entretanto, esse efeito foi verificado por Lavezzo et al. (1980) em trabalho com capim-elefante, aos 28 dias, quando o teor de FB foi de $16,5 \%$, enquanto que, aos 168 dias esse teor foi de $33,5 \%$. Resultados encontrados por Drudi \& Favoretto (1987) mostraram diferenças entre os intervalo entre cortes de 35 e 42 dias, para o capim-andropógon com teores de FB de 31,8 e 33,8\%, respectivamente.

Com relação à variação no valor nutritivo da forragem com o maior intervalo entre cortes, Lavezzo et al. (1980) encontraram variações entre 8,8\% e 
$22,6 \%$ na PB com forragens colhidas aos 168 e 28 dias, respectivamente. Também, Drudi \& Favoretto (1987) relataram teores de PB maiores nas plantas colhidas a cada 35 dias, relativamente àquelas colhidas a cada 42 dias. Em capim-Colonião (Panicum maximum Jacques), Gomide et al. (1985) revelaram uma variação de $9,8 \%$ para $7,5 \%$ de PB quando ocorreu aumento no intervalo entre cortes.

Decréscimos acentuados no teor de PB à medida que se aumenta o intervalo entre cortes foram relatados para várias gramíneas de clima tropical (Andrade \& Gomide, 1971; Burton et al., 1963; Cecato, 1993; Costa et al., 1992; Davis et al., 1987; Drudi \& Favoretto, 1987; Euclides et al., 1990; Fianu \& Wingh, 1984; Milford \& Haydock, 1965; Ruggieri et al., 1995; Vicent-Chandler et al., 1959 e Vieira \& Gomide, 1970). Para Viana et al. (1976), trabalhando com capim-elefante, a ampliação de 24 para 98 dias no intervalo entre cortes resultou em redução no teor de $\mathrm{PB}$ de $16,6 \%$ para $7,5 \%$, respectivamente. Acunha \& Coelho (1997) obtiveram, para capim-elefante, $12,4 \%$ e $6,3 \%$ de PB para os intervalo entre cortes de 28 e 140 dias, respectivamente.

Segundo Costa (1995), a melhor idade de corte do capim-Marandu, visando conciliar melhor produção e melhores teores de PB situa-se entre 56 e 70 dias de crescimento vegetativo.

O aumento no intervalo entre cortes gera também, de modo geral, decréscimo na digestibilidade in vitro, tanto da matéria orgânica (DIVMO) quanto da matéria seca (DIVMS), como observado por Gomide et al. (1985) e Ruggieri et al. (1995). Estudos que têm relacionado digestibilidade com a idade de crescimento das plantas forrageiras têm demonstrado, geralmente, uma relação linear negativa entre essas variáveis (Gomide et al., 1969). A diminuição percentual da digestibilidade foi reportada por Andrade \& Gomide (1971) em capim-elefante, com DIVMS variando de 50,3\% aos 28 dias para $21,1 \%$ aos 196 dias de crescimento. Acunha \& Coelho (1997) obtiveram digestibilidades decrescentes de $61,1 \%$ a $50,7 \%$ à medida que se estendeu 0 intervalo entre cortes de 28 para 140 dias. 
Outra alteração ocorrida quando do aumento no intervalo entre cortes é a variação da proporção de lâminas foliares em relação às hastes. Alterações na relação folha/haste $(F: H)$ resultam em diferenças de grande importância do ponto de vista de valor nutritivo e de manejo das espécies forrageiras. Com o avanço do desenvolvimento da planta forrageira, a participação da porção folha diminui progressivamente à medida que se intensifica o processo de alongamento do colmo, conseqüência do maior aporte de assimilados para as estruturas, resultando na redução gradativa da relação folha/haste (Formoso, 1987; Haggar, 1970 e Machado et al., 1984).

Santos et al. (1999) trabalharam com capins do gênero Panicum e citaram que a relação folha/haste foi reduzida, de 1,32 para 0,99 , com o aumento do intervalo entre pastejo de 28 para 48 dias. De acordo com Pinto et al. (1994), o valor da relação folha/haste deve ter limite inferior igual a um. Essa relação é uma variável de grande importância para a nutrição animal e para o manejo das plantas forrageiras. A alta relação $\mathrm{F}: \mathrm{H}$ representa forragem de elevado teor de proteína, digestibilidade e consumo (Wilson, 1982; Wilson \& Minson, 1980 e Wilson \& Mannetje, 1978), uma vez que um maior valor nutritivo é atribuído à lâmina foliar (Nascimento Júnior \& Pinheiro, 1975 e Pedreira \& Silveira, 1971).

Acunha \& Coelho (1997) encontraram um gradiente de participação de lâmina foliar no capim-elefante variando de $88 \%$ a $59 \%$ quando o intervalo entre cortes passou de 28 para 140 dias. Nesse mesmo experimento, o percentual de haste variou de $12 \%$ para $41 \%$. Camarão et al. (1994) obtiveram, durante 12 meses, em pastagens de Brachiaria humidicola, proporções de folhas variando entre $34,3 \%$ e $46,2 \%$, hastes variando entre $28,6 \%$ e $45,5 \%$ e material morto variando entre $13,5 \%$ e $37,1 \%$. 


\subsection{Silagem de capins tropicais e seu valor nutritivo}

De acordo com Wilkins et al. (1999) é indiscutível o papel da silagem como volumoso suplementar na alimentação de ruminantes em períodos de escassez de forragem. Ainda, segundo o autor, a silagem de capim vem surgindo como uma alternativa às culturas tradicionais, tendo como vantagem as características de uma cultura perene, possibilidade de manutenção de elevadas taxas de lotação na propriedade e permitir grande flexibilidade em termos de manejo na tomada de decisões.

O processo de ensilagem não melhora a composição química da forragem, mas visa mantê-la estável por mais tempo (McDonald et al., 1991). Por isso é interessante que o material a ser ensilado contenha elevado valor nutritivo original, principalmente tendo em vista o custo operacional do processo que incide sobre esse volumoso.

Nussio et al. (2000) relataram que as áreas de pastagens formadas pelas espécies $B$. decumbens e $B$. brizantha vêm sendo utilizadas, alternativamente, para a produção de silagens de capins tropicais substituindo a altura às gramíneas do gênero Panicum, com produções semelhantes e valor nutritivo da forragem ligeiramente superior.

O potencial de uma espécie forrageira para ensilagem é dependente do seu teor de umidade, teor de carboidratos solúveis e poder tampão no momento do corte (McCullough, 1977; McDonald et al., 1991; Lavezzo, 1992 e Reis \& Coan, 2001). Esses parâmetros influem, de maneira decisiva, na natureza da fermentação e na conservação da massa ensilada. Esse vem sendo o principal entrave encontrado pelos técnicos para confecção de silagem de gramíneas tropicais de qualidade. $\mathrm{O}$ alto teor de umidade, o alto poder tampão (PT) e um baixo teor de carboidratos solúveis (CS) influenciam negativamente o processo fermentativo, impedindo o rápido decréscimo do $\mathrm{pH}$ e prejudicando o valor nutritivo. Weissbach et al. (1974) apresentaram uma relação entre CS e PT 
capaz de predizer a qualidade do produto ensilado. Weissbach \& Honig ${ }^{1}$, citados por Oude Elferink et al. (2000), relataram que a capacidade de fermentação (CF) é diretamente proporcional aos teores de matéria seca e de carboidratos solúveis, e inversamente proporcional ao poder tampão, como mostra a Equação 1.

$\mathrm{CF}=\mathrm{MS}+8 \times\left(\frac{\mathrm{CS}}{\mathrm{PT}}\right)$

onde:

$\mathrm{CF}$ = capacidade de fermentação;

MS = teor de matéria seca (\%);

CS = teor de carboidratos solúveis (\% MS);

PT = poder tampão (emg $\left.100 \mathrm{~g} \mathrm{MS}^{-1}\right)$.

Valores de CF superiores a 35 são considerados satisfatórios. Substituindo os valores de CS (1,1\% MS), PT (21,6 emg $\left.100 \mathrm{~g} \mathrm{MS}^{-1}\right)$ e MS $(22,9 \%)$ encontrados nas silagens avaliadas por Bernardes (2003) para capimMarandu cortado aos 58 dias de rebrotação, obtém-se estimativa do valor de CF de 23,3, caracterizando, uma forragem com capacidade de fermentação insatisfatória.

A conservação de gramíneas tropicais, sob a forma de silagem, apresenta limitações como: maior concentração de componentes de parede celular e, conseqüentemente, menores teores de carboidratos fermentescíveis,

\footnotetext{
${ }^{1}$ WEIISBACH, F.; HONIG, H. Über die vorhersage und steuerung das garungsverlaufs bei der silierung von grunfutter aus extensivem anbau. Landbauforschung Volkenrode, n.1, p. 10-17, 1996.
} 
quando comparadas às gramíneas de clima temperado (Wilkins et al., 1999 e McDonald et al., 1991).

Para Balsalobre et al. (2001), plantas forrageiras do gênero Brachiaria e Panicum têm sido empregadas largamente no processo de ensilagem de capins em virtude da ampla distribuição nacional.

A maior parte das gramíneas tropicais, apesar dos baixos teores de carboidratos solúveis, tem potencial para ensilagem. Entretanto, forragens com maior proporção de folhas devem ser preferidas. Essas plantas forrageiras, além de melhor valor nutritivo, apresentam maiores teores de MS, em especial as braquiárias, que se constituem em opção favorável devido à elevada relação folha/haste (Balsalobre et al., 2001). Segundo o mesmo autor, essa última característica pode ser melhorada através do manejo adequado do intervalo entre cortes.

De acordo com Logan \& Lister (1979), a silagem confeccionada com capins colhidos no início do crescimento vegetativo apresenta maior proporção de proteína, em relação aos nutrientes totais, quando comparada à silagem de milho. Por outro lado, segundo McDonald et al. (1991), silagens confeccionadas com forragens contendo baixo teor de MS favorecem perdas por efluente e propiciam o desenvolvimento de bactérias do gênero Clostridium, responsáveis por fermentações secundárias indesejáveis. Ainda, segundo esses autores, o desenvolvimento de tais bactérias é favorecido quando a atividade de água é aumentada, devido ao excesso de umidade da forragem.

Se a forragem for colhida tardiamente, ou seja, em estádio fisiológico avançado, a silagem deverá apresentar menor valor nutritivo. Em contrapartida, se ensilada em estádio de desenvolvimento anterior, algumas características podem interferir negativamente no processo fermentativo: alto teor de umidade e o alto poder tampão (Woolford, 1984).

O valor nutritivo das plantas forrageiras é determinado pela sua composição química e pelos nutrientes diretamente responsáveis pela digestibilidade da matéria seca, os teores de PB e de fibra insolúvel em 
detergente ácido (FDA) (Nussio et al., 1998 e Euclides et al., 1995). A lignina exerce grande influência sobre a taxa de degradação e a degradabilidade efetiva da parede celular dos alimentos volumosos (Van Soest, 1994). A fração fibra insolúvel em detergente neutro (FDN) tem grande efeito sobre o consumo de alimentos em ruminantes (Mertens, 1994).

Com relação às características bromatológicas da silagem de capimMarandu, Nussio et al. (2000), em revisão sobre o assunto, encontraram teores médios de MS de 25,9\%, PB de 7,0\%, FDN de 77,7\%; FDA de 51,6\% e DIVMS de $50,7 \%$.

Silveira et al. (1973b), analisando silagens de capim-elefante confeccionadas em diferentes intervalos entre cortes, encontraram digestibilidade de $62,3 \%$ para a forragem cortada aos 41 dias e de $47,9 \%$ para a forragem cortada aos 121 dias de rebrotação.

Igarasi (2002) trabalhou com silagens de capim-Tanzânia (Panicum maximum Jacq. cv. Tanzânia) submetidos a diferentes tratamentos que modificaram o teor de matéria seca, inoculação microbiana e tamanho de partícula, tanto no verão como no inverno. No tratamento controle, obteve teores médios de PB de 6,3 e 5,5\%, para silagens de verão e de inverno, respectivamente; o FDN variou de $67,5 \%$ no verão a $63,5 \%$ no inverno e os teores de FDA encontrados foram de $45,9 \%$ e $38,5 \%$ no verão e inverno, respectivamente.

Manno et al. (2002), trabalhando com silagens de capim-Coastcross (Cynodon dactylon (L.) Pers.), encontraram valores de PB de 12,6\%, FDN de $72,8 \%$ e de FDA de $36,4 \%$ quando a forragem foi colhida aos 45 dias de crescimento vegetativo, emurchecida por duas horas no campo e ensilada sem aditivo.

Ribeiro et al. (2002), trabalhando com silagens de capim B. decumbens submetida a três períodos de rebrotação (42, 56 e 70 dias), encontraram valores de PB de $6,8 \%$ aos 42 dias, que foi elevado para $7,6 \%$ aos 56 dias e decresceu para $5,3 \%$ aos 70 dias. Os teores de FDN aumentaram à medida 
que a idade de rebrotação aumentou, sendo de $61,3 \%, 68,9 \%$ e $73,4 \%$ para os 42, 56 e 70 dias, respectivamente. O teor de FDA sitou-se em torno de $41 \%$ para as idades de 42 e 56 dias, e aumentou para $46,9 \%$ na silagem confeccionada com forragens colhidas aos 70 dias de crescimento vegetativo.

\subsection{Tamanho de partículas, condutividade elétrica e atividade de água}

A densidade da massa de forragem picada, observada no fechamento do silo, determina a quantidade de oxigênio residual (Nussio et al., 2002). Dentre os fatores que alteram a densidade da forragem ensilada estão: o peso e a pressão aplicados na compactação, o tempo de compactação, a espessura da camada de forragem adicionada ao silo, a taxa de enchimento do silo, o teor de MS do material e o tamanho de partícula do mesmo (Balsalobre et al., 2001 e Holmes \& Muck, 1999). Segundo Nussio et al. (2002), existem situações onde a redução do tamanho médio de partículas ainda é limitada pelas colhedoras de forragem, constituindo, assim, o principal fator restritivo do aumento da densidade da silagem.

Segundo Gale \& Knight (1979), o tamanho de partícula é um importante fator na produção de silagem, influenciando o requerimento de potência da colhedora, densidade no transporte e no silo, e valor nutricional do produto final. O tamanho de partícula do material ensilado consiste na mensuração da estratificação das partículas em peneiras seqüenciais e determina alteração na compactação, influenciando o processo fermentativo (Igarasi, 2002). O maior tamanho da partícula determinaria a queda mais lenta do $\mathrm{pH}$, o que promoveria elevação das perdas de MS, particularmente de carboidratos solúveis em água e proteína (Woolford, 1972). O tamanho médio de partículas considerado ideal pode ser obtido pela colheita da forragem em estádio de maturidade adequado e através do processamento físico exercido pela colhedora de forragens sendo, nesse caso, fundamental a manutenção da afiação e posicionamento do 
conjunto de facas. Além disso, a diminuição no tamanho de partícula pode interferir no aumento da taxa de passagem da forragem pelo trato digestivo, promovendo alterações no consumo voluntário do animal, e, por conseqüência, no seu desempenho (Igarasi, 2002).

O processamento físico através da picagem e condicionamento mecânico pode melhorar o processo de conservação da forragem ensilada, permitindo melhor acomodação do material dentro do silo, diminuindo a fase aeróbica do processo (Lavezzo, 1985). Além disso, tamanhos de partícula reduzidos podem favorecer a fermentação, facilitar a compactação, promovendo maior superfície de contato entre substrato e microrganismos (Aguiar et al., 2001 e Nussio et al., 2002).

Vários métodos têm sido empregados para a mensuração do tamanho das partículas, dentre os quais destaca-se o método Penn State Particle Size Separator. Porém, no que diz respeito às silagens de capins tropicais, o mesmo não tem apresentado adequação em virtude do elevado tamanho médio de partículas encontradas nesses volumosos (> $4 \mathrm{~cm}$ ). Igarasi (2002) observou que grande parte do material estratificado (63-91\%) ficou retido na peneira com os maiores orifícios (19 mm de diâmetro). Em virtude disso, no experimento conduzido por Igarasi (2002), mesmo havendo diferentes regulagens para tamanhos de partículas, o método de estratificação em peneiras seqüenciais não se mostrou adequado para se evidenciar a efetividade do processamento físico. Assim, com o objetivo de ganhar maior sensibilidade nessa avaliação, procedeu-se à mensuração da condutividade elétrica (CE) do extrato aquoso, seguindo o método de Kraus et al. (1997), evidenciando que partículas menores deveriam proporcionar maior liberação de conteúdo celular do tecido vegetal para o extrato aquoso.

O efeito de tratamentos de picagem da forragem, ou seja, ruptura da parede celular da planta, ocasionando a drenagem do conteúdo celular, pode ser quantificado por meio da determinação da CE (Pauly, 1999). O valor da CE de uma amostra corresponde aos íons liberados pela forragem dispersos em 
solução, de forma que amostras com maior teor de conteúdo celular extravasado possuem maior CE. De acordo com Kraus et al. (1997), a extensão do dano causado pela ruptura celular das plantas pode ser estudada através da CE.

Lavezzo (1985) recomendou que a trituração de capim visando a ensilagem deveria procurar obter tamanho médio de 30-50 mm para permitir uma melhor compactação e, por conseguinte, garantir um ambiente anaeróbico mais rapidamente. Para McDonald et al. (1991), o tamanho de partículas inferior a 20-30 mm pode levar a efeitos positivos sobre a disponibilidade de carboidratos solúveis e, conseqüentemente, estímulo ao crescimento de bactérias láticas.

Entretanto, a redução do tamanho de partículas da forragem em silagens de baixo teor de MS pode provocar maior perda por efluente e aumento da atividade de água (Aw) (Nussio et al., 2002). A Aw refere-se ao percentual de água livre disponível ao crescimento de microrganismos, é mensurada em pressão relativa determinada pela relação de uma constante expressa pelo peso das moléculas ou íons do suco da forragem e MS do material (Greenhill, 1964). Segundo Balsalobre et al. (2001), a redução da Aw, em decorrência da elevação da pressão osmótica, ocorre em silagens com teores de MS mais elevados, onde se observa mínima geração de efluentes.

\subsection{Perdas inerentes ao processo de ensilagem: efluentes e gases}

O efluente das silagens contém grande quantidade de compostos orgânicos como açúcares, ácidos orgânicos, proteínas e outros componentes. Sendo assim, constitui uma forma importante de perda de valor nutritivo durante o processo de conservação (McDonald et al., 1991). As perdas via efluente estão positivamente correlacionadas à Aw, sugerindo incrementos simultâneos dessas variáveis. A Aw do material, assim como a CE, estão associadas ao teor 
de matéria seca (MS) da forragem e, também, ao processamento físico aplicado ao material no momento do corte (Balsalobre et al., 2001).

Segundo Haigh (1999), vários trabalhos procuraram quantificar as perdas por efluente via modelos matemáticos, porém esses modelos levaram em conta apenas o teor de MS da forragem, deixando de lado fatores importantes como o tipo e a dimensão do silo, o grau de compactação, o tipo de processamento utilizado no material ensilado e a presença de aditivos. Isso, de acordo com Balsalobre et al. (2001), caracteriza uma distorção de abordagem, visto não ser observada correlação negativa, em inúmeros trabalhos, entre teor de MS e produção de efluente.

Loures (2000), avaliando silagens de capim-elefante com alto teor de umidade (13\% MS) submetidas a densidades de compactação (356 a $791 \mathrm{~kg}$ $\mathrm{m}^{-3}$ ), observou que a produção de efluente foi condicionada aos aumentos na pressão de compactação.

Haigh (1999), trabalhando com silos horizontais de larga escala, aproximadamente 100 t, propôs uma equação para silagem de azevém perene (Lolium perenne) consorciado com trevo branco (Trifolium repens), submetida a diferentes tratamentos (Figura 1). Essa simulação revelou menor produção de efluentes em silagens com teor de MS elevado e um rápido decréscimo na estimativa da geração de efluentes conforme aumentou-se o teor de MS de silagens mais úmidas (Balsalobre et al., 2001).

Aguiar et al. (2001) reportaram que, em capim-Tanzânia ensilado com teor de umidade original, a produção estimada de efluente foi de 40 a $50 \mathrm{~L} \mathrm{t}^{-1}$ de massa verde, variando de acordo com o grau de processamento da massa. No entanto, a produção de efluente, quando essa forragem sofreu emurchecimento ou adição de $10 \%$ de polpa cítrica, na base da massa verde, foi menor que $10 \mathrm{~L}$ $\mathrm{t}^{-1}$ de massa verde. Quando os autores compararam os tratamentos que elevaram o teor de MS da massa ensilada, verificaram menores produções de efluente no tratamento emurchecido, embora com teores de MS semelhantes, sugerindo que essa produção estaria associada não apenas ao teor de MS, 
mas, também, à atividade de água do material ensilado. Igarasi (2002) encontrou produções de efluente variando entre 1,8 e $11,1 \mathrm{~kg} \mathrm{t}^{-1}$ massa verde no inverno e, entre 20,2 e $66,8 \mathrm{~kg} \mathrm{t}^{-1}$ de massa verde, nos diversos tratamentos de verão.

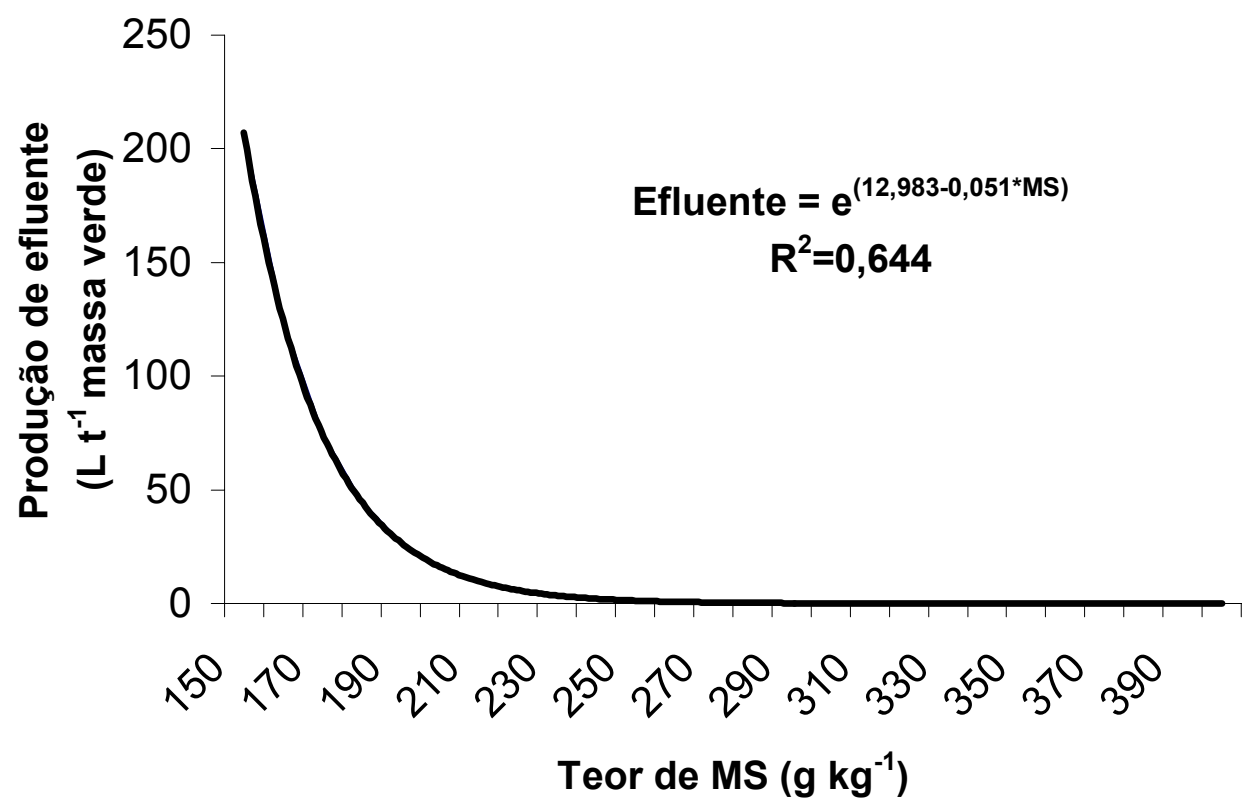

Figura 1 - Estimativa da produção de efluente em relação ao teor de matéria seca. Fonte: Haigh (1999)

Outra importante forma de perda durante o processo de ensilagem é a perda por gases. De acordo com Balsalobre et al. (2001) e McDonald et al. (1991), essas perdas estão associadas ao tipo de fermentação ocorrida no processo. Quando a fermentação ocorre via bactérias homofermentativas (fermentação lática exclusiva), utilizando a glicose como substrato para produzir ácido lático, as perdas são inferiores. Entretanto, quando a via de produção ocorre via citrato ou malato, ocorre produção de $\mathrm{CO}_{2}$ e álcool (etanol e manitol) e as perdas por gases são consideráveis. Essa fermentação é realizada por 
bactérias heterofermentativas, enterobactérias e por leveduras (McDonald et al., 1991).

Em condições de umidade excessiva da massa de forragem, como é o caso das silagens de capins tropicais, as perdas por gases são maiores, decorrentes da fermentação butírica promovida por Clostridium sp., responsável tanto por elevadas perdas de MS quanto de energia (McDonald et al., 1991).

Crestana et al. (2000) trabalharam com silagens de capim-Tanzânia com baixos teores de MS (20\%) e verificaram que, à medida que havia redução do tamanho de partícula, avaliado pela porcentagem de forragem retida em peneira de $19 \mathrm{~mm}$ pelo método Penn State Particle Size Separator, ocorria significativa redução na produção de gases. Entretanto, nessas condições era observado aumento compensatório da produção de efluentes, mantendo-se inalteradas as perdas totais por volta de $27 \%$. Para Igarasi (2002) as perdas por gases foram menores no inverno (3,5\% da MS) que no verão $(7,3 \%$ da $\mathrm{MS})$ em silagens de capim-Tanzânia que não receberam aditivos ou tratamentos para elevação do teor de MS.

Para Balsalobre et al. (2001), apesar da redução da perda total de MS não ser significativa em silagens obtidas a partir de forragem picada finamente, a redução no tamanho de partícula deve ser objetivo de qualquer programa de ensilagem, pois o menor tamanho da partícula apresenta menor custo de produção por determinar maior densidade de forragem e, por isso, redução no custo de transporte. Além disso, promove menores perdas físicas durante a retirada e distribuição da silagem no cocho. No entanto, o maior benefício em silagens de menor tamanho de partícula está relacionado ao maior potencial de consumo dessas silagens, como foi observado por Paziani et al. (2003), quando aumentos de $12,2 \%$ no consumo de MS foi associado a incrementos de $11,58 \%$ no ganho de peso, com a redução do tamanho médio de partículas de 13,2 para $7,5 \mathrm{~mm}$. 


\section{PRODUÇÃO, COMPOSIÇÃO MORFOLÓGICA E QUÍMICO- BROMATOLÓGICA DO CAPIM-MARANDU, SUBMETIDO A INTERVALOS ENTRE CORTES}

\section{Resumo}

Os objetivos desse estudo foram de verificar o comportamento da produção de matéria seca (MS), a composição morfológica e o valor nutritivo do capim-Marandu (Brachiaria brizantha (Hochst. ex A. Rich.) Stapf cv. Marandu) submetido a intervalo entre cortes com o objetivo de sugerir recomendações de manejo para a otimização do sistema de exploração dessas plantas forrageiras. Os tratamentos consistiram em seis intervalos entre cortes (T15, T30, T45, T60 T75 e T90), com forragens colhidas, respectivamente, aos 15, 30, 45, 60, 75 e 90 dias de rebrotação, conduzidos ao longo de 12 meses. O delineamento experimental constituiu-se de blocos completos casualizados sendo seis tratamentos e quatro blocos. Os dados foram agrupados em ciclos de cortes de 90 dias para efeito de comparação entre os tratamentos. Foi avaliada a produção de MS, produção de MS digestível, composição morfológica percentual (folhas, hastes e material morto) e a composição químicobromatológica da forragem em proteína bruta (PB), fibra insolúvel em detergente neutro (FDN) e digestibilidade verdadeira in vitro da matéria seca (DVIVMS). A forragem foi cortada com auxílio de facas a uma altura de $5 \mathrm{~cm}$ acima do nível do solo nas parcelas experimentais de área de $100 \mathrm{~m}^{2}$. As produções acumuladas de MS foram menores $(P<0,01)$ nos tratamentos T30 e T45 (21 t ha- ano $\left.^{-1}\right)$ que nos demais $\left(27 \mathrm{t} \mathrm{ha}^{-1}\right.$ ano $\left.^{-1}\right)$ e a produção de MS 
digestível (16,2 $\mathrm{t} \mathrm{ha}^{-1}$ ano $^{-1}$ ) seguiu a mesma tendência. As alterações encontradas nas variáveis estudadas foram, sobretudo, decorrentes das variações ambientais, as quais levaram a alterações na composição morfológica e químico-bromatológica. Em geral, maiores intervalos entre cortes proporcionaram redução na porcentagem de folhas e aumento na participação das hastes que, como conseqüência, levaram a decréscimos nos teores de PB e DVIVMS, além de aumentos nos teores de FDN. A otimização do intervalo entre cortes visando conciliar elevada produção de MS e valor nutritivo satisfatório ocorreu ao redor dos 60 dias de crescimento vegetativo, quando a menor digestibilidade foi compensada pela maior produção de MS.

\section{DRY MATTER YIELD, MORPHOLOGICAL COMPOSITION AND NUTRITIVE VALUE OF MARANDU GRASS SUBMITTED TO CUTTING INTERVALS}

\section{Summary}

The objectives of this study were to evaluate the dry matter (DM) yield, morphological composition and nutritive value of Marandu grass (Brachiaria brizantha (Hochst. ex A. Rich.) Stapf cv. Marandu) submitted to cutting intervals. The randomized block design, with 6 cutting intervals (treatments), 4 replications each, was carried out during 12 months. Treatments consisted of Marandu grass, harvested above the stubble height $(5 \mathrm{~cm})$ at 15, 30, 45, 60, 75 and $90-\mathrm{d}$ intervals. The experimental data were pooled in 90-d interval to compare treatments. Forage dry matter (DM) yield, digestible DM yield, morphological composition (leaves, stems, and dead material) and nutritive value (crude protein - CP, neutral detergent fiber - NDF and in vitro true digestible dry matter - IVTDDM) were determined. DM yield was lower $(P<0.01)$ at $30-d$ and $45-d$ cutting intervals $\left(21 \mathrm{t} \mathrm{ha}^{-1}\right.$ year $^{-1}$ ) as compared to $15,60,75$ and $90-\mathrm{d}$ cuts (27 t $\mathrm{ha}^{-1}$ year $\left.^{-1}\right)$. Digestible DM yield followed the same pattern. Values observed in 
the measured parameters were probably due to environmental conditions, leading to morphological and chemical composition changes. In general, samples harvested at longer cutting intervals showed a decrease in leaves, CP content and IVTDDM as the proportion of stems and NDF content were increased. In order to optimize the harvesting management, a 60-d cutting interval is recommended since it combined the benefits of higher DM yield associated with suitable nutritive value.

\subsection{Introdução}

O Brasil possui características climáticas que favorecem a exploração de forragens com elevado potencial de produção de biomassa. As áreas de pastagem do nosso país compreendem, segundo dados da FAO (2003), aproximadamente 180 milhões de hectares, isto é, cerca de $20 \%$ do território nacional é ocupado por plantas forrageiras. Além da importância territorial, cerca de $90 \%$ dos bovinos têm sua exploração produtiva apoiada em pastagens.

Em decorrência da estacionalidade de produção, variações ambientais e maturação fisiológica as plantas forrageiras sofrem mudanças em sua composição química, destacando-se maior espessura da parede celular e lignificação, com conseqüente redução no teor de compostos nitrogenados (Minson, 1990 e Van Soest, 1994). Ocorre ainda, no Brasil, assim como nos outros países do trópico Sul, uma marcante estacionalidade da produção de forragens, sendo esse o principal fator de restrição na exploração da produção pecuária nacional. Ocorrem, durante o ano, períodos cíclicos de alta e baixa produção de forragem, característica das gramíneas de clima tropical, que conflita com o benefício do alto potencial de produção de matéria seca por área. Segundo Corsi \& Santos (1995), as forragens tropicais são capazes de produzir 
aproximadamente o dobro de matéria seca das forragens de clima temperado, porém com menor valor nutritivo.

Dentre as espécies forrageiras existentes, as do gênero Brachiaria apresentam destacada participação no mercado brasileiro, adaptando-se às variadas condições de clima e solo. Porém sua extensa utilização deve-se, principalmente, à sua adaptação às condições de solos com baixa e média fertilidade. Apesar da destacada representação da braquiária decumbens dentre as espécies do gênero, essas gramíneas vêm apresentando declínio da produção após ciclos de pastejo. A partir da década de 80 , foi introduzido pela EMBRAPA o capim-Marandu, passando a ser largamente utilizado em pastejo e, mais recentemente, tem sido despertado o interesse no seu uso para os processos de conservação.

O intervalo entre cortes é um fator importante de manejo num sistema de produção de silagem. Para tanto, é necessário o acompanhamento da produção e do valor nutritivo ao longo do ano. Com o advento da metodologia da espectroscopia de reflectância de infravermelho proximal tem sido viabilizada a condução de estudos que possibilitem uma análise em menor tempo e capaz de predizer o valor nutritivo das forragens avaliadas.

O objetivo desse estudo foi de verificar o comportamento da produção de matéria seca, a composição morfológica e o valor nutritivo do capim-Marandu submetido a intervalo entre cortes com o objetivo de sugerir recomendações de manejo para a otimização do sistema de exploração dessas plantas forrageiras. 


\subsection{Material e Métodos}

\subsubsection{Material}

\subsubsection{Espécie vegetal}

De acordo com Cronquist (1988) a espécie estudada classifica-se como pertencente à divisão Magnoliophyta; à classe Liliopsida; à subclasse Commelinidae; à ordem Cyperales; à família Poaceae; à subfamília Panicoideae; à tribo Panicodae; à subtribo Paniceae; ao gênero Urochloa; à espécie Urochloa brizantha (Hochst. ex A. Rich.) Webster; à variedade Urochloa brizantha (Hochst. ex A. Rich.) Webster var Marandu.

Segundo Renvoize et al. (1996) a espécie é tradicionalmente conhecida como Brachiaria brizantha (Hochst. ex A. Rich) e possui diversos nomes comuns (brizantha, braquiarão, capim-Marandu, brizantão e Marandu). Entretanto Webster (1988) concluiu que várias braquiárias são erroneamente classificadas como pertencentes ao gênero Brachiaria, pois, na verdade, são parte das espécies do gênero Urochloa.

Para se manter o rigor científico e evitar-se o conflito nomenclatura, a denominação utilizada, a partir deste ponto, será capim-Marandu.

\subsubsection{Local do experimento}

O experimento foi conduzido em área localizada com as coordenadas geográficas aproximadas de $22^{\circ} 42^{\prime}$ de latitude sul, $47^{\circ} 38^{\prime}$ de longitude oeste e altitude de $546 \mathrm{~m}$, pertencente ao Departamento de Aviação Civil (DAC) do Estado de São Paulo e utilizada sob concessão ao Departamento de Produção Animal - Setor Ruminantes, USP/ESALQ, em Piracicaba, SP. O período experimental foi de 01 de agosto de 2001 a 18 de julho de 2002, totalizando 352 dias de duração. 


\subsubsection{Solo da área experimental}

ARGISSOLO VERMELHO-AMARELO Eutrófico típico (Empresa Brasileira de Pesquisa Agropecuária - EMBRAPA, 1999) e cuja composição química média é apresentada na Tabela 1.

Tabela 1. Análise química do solo da área experimental

\begin{tabular}{cccccccccc}
\hline $\mathrm{pH}$ & $\mathrm{MO}$ & $\mathrm{P}$ & $\mathrm{K}$ & $\mathrm{Ca}$ & $\mathrm{Mg}$ & $\mathrm{H}+\mathrm{Al}$ & $\mathrm{SB}$ & $\mathrm{T}$ & $\mathrm{V}$ \\
$\mathrm{CaCl}_{2}$ & $\mathrm{~g} \mathrm{dm}^{-3}$ & $\mathrm{mg} \mathrm{dm}^{-3}$ & - & - & - & & & & \\
5,3 & 20 & 11 & 1,5 & 22 & 16 & 18 & 39,5 & 57,5 & 69 \\
\hline
\end{tabular}

\subsubsection{Implantação da área}

A área começou a ser implantada em 14 de janeiro de 2001, data na qual foi aplicado glifosato na dose de $8 \mathrm{~L} \mathrm{ha}^{-1}$ com o intuito de dessecação para o estabelecimento do capim-Marandu sob plantio direto, na gleba anteriormente destinada à produção de feno de capim de Rhodes (Chloris gayana Kunth. cv. Callide). Após quatro dias procedeu-se a semeadura $\left(8 \mathrm{~kg} \mathrm{ha}^{-1}\right.$ de sementes puras viáveis). Em 01 de agosto de 2001 foi realizado o primeiro corte de uniformização das unidades experimentais, através da colhedora de forragem da marca Casale ${ }^{\circledR}$, modelo CF 2000 Super, regulada para cortar a massa de forragem a uma altura de $5 \mathrm{~cm}$ acima do nível do solo.

\subsubsection{Clima}

Os dados climáticos referentes ao período experimental foram coletados no posto meteorológico do Departamento de Ciências Exatas da USP/ESALQ, localizado aproximadamente a $1000 \mathrm{~m}$ da área experimental (Tabela 2). 
Tabela 2. Radiação solar global média mensal, insolação diária média mensal, precipitação total mensal e temperaturas médias mensais durante o período experimental

\begin{tabular}{lcccccc}
\hline \multirow{2}{*}{ Mês/Ano } & $\begin{array}{c}\text { Radiação } \\
\text { Global }\end{array}$ & $\begin{array}{c}\text { Insolação } \\
\text { Diária }\end{array}$ & $\begin{array}{c}\text { Precipitação } \\
\text { cal cm }\end{array}$ & \multicolumn{4}{c}{ Temperatura } \\
& $\mathrm{dia}^{-1}$ & $\mathrm{~h} \mathrm{dia}^{-1}$ & $\mathrm{~mm}$ & & ${ }^{\circ} \mathrm{C}$ & \\
\hline Agosto/2001 & 391 & 7,3 & 44,2 & 28,0 & 20,2 & 12,4 \\
Setembro/2001 & 425 & 7,2 & 48,4 & 28,1 & 21,4 & 14,7 \\
Outubro/2001 & 496 & 7,9 & 173,3 & 29,5 & 22,8 & 16,1 \\
Novembro/2001 & 466 & 6,7 & 152,4 & 30,7 & 24,7 & 18,7 \\
Dezembro/2001 & 427 & 5,4 & 204,2 & 29,2 & 24,0 & 18,7 \\
Janeiro/2002 & 410 & 4,7 & 320,2 & 29,8 & 24,5 & 19,3 \\
Fevereiro/2002 & 404 & 5,1 & 187,9 & 29,0 & 23,9 & 18,8 \\
Março/2002 & 462 & 7,9 & 274,6 & 32,0 & 25,8 & 19,5 \\
Abril/2002 & 392 & 8,7 & 27,2 & 31,8 & 24,7 & 17,6 \\
Maio/2002 & 298 & 6,1 & 112,4 & 26,8 & 20,7 & 14,5 \\
Junho/2002 & 307 & 7,4 & 0,0 & 27,9 & 20,3 & 12,6 \\
Julho/2002 & 267 & 6,0 & 23,4 & 25,2 & 17,7 & 10,2 \\
\hline
\end{tabular}

Fonte: USP/ESALQ, 2002.

\subsubsection{Métodos}

\subsubsection{Delineamento experimental e tratamentos}

O experimento foi realizado seguindo o delineamento de blocos completos casualizados, com quatro repetições. Os tratamentos corresponderam a seis intervalo entre cortes de 15, 30,45, 60, 75 e 90 dias, respectivamente, T15, T30, T45, T60, T75 e T90 que, conforme foram alcançados, procedeu-se o rebaixamento à mesma altura inicial de $5 \mathrm{~cm}$ acima do nível do solo. O experimento apresentou um total de 24 parcelas ou 
unidades experimentais ( 4 blocos $\times 6$ unidades experimentais), com área média de $100 \mathrm{~m}^{2}$ cada, perfazendo um total de $2400 \mathrm{~m}^{2}$ (Figura 2).

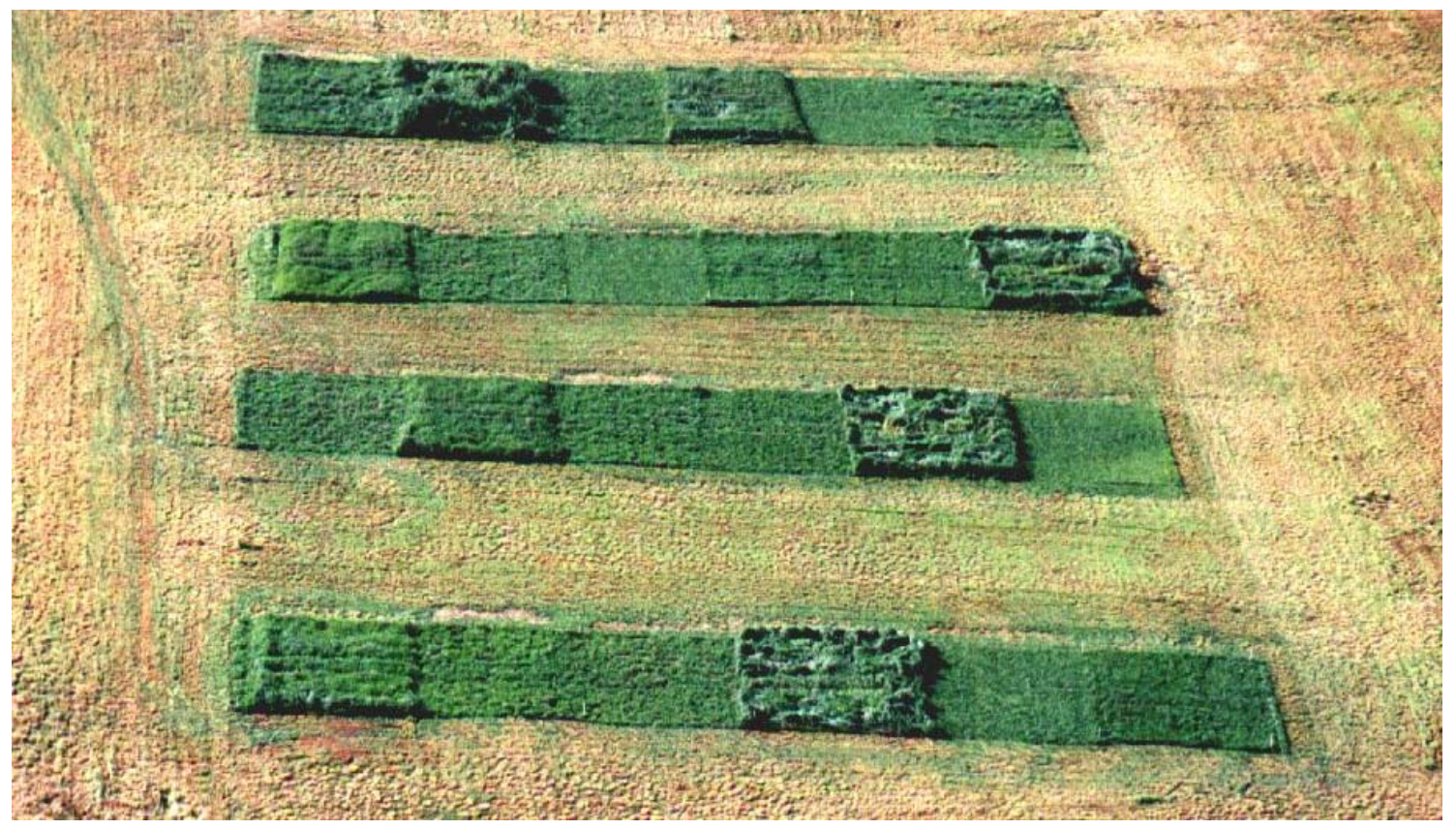

Figura 2 - Vista aérea da área experimental

Apesar de ter-se programado um calendário para os cortes da forragem com base nos intervalos entre cortes planejados, frustrações climáticas ou logísticas determinaram variações nas datas de colheita, conforme pode ser observado na Tabela 3. 
Tabela 3. Intervalo entre cortes planejado, intervalo efetivo médio, mínimo e máximo nos seis tratamentos estudados, durante os 352 dias de período experimental

\begin{tabular}{lcccc}
\hline \multirow{2}{*}{ Tratamento } & $\begin{array}{c}\text { Intervalo entre cortes } \\
\text { planejado (dias) }\end{array}$ & \multicolumn{3}{c}{ Intervalo entre cortes efetivo (dias) } \\
\cline { 3 - 5 } & 15 & Médio & Mínimo & Máximo \\
\hline T15 & 30 & 14 & 12 & 17 \\
T30 & 45 & 42 & 24 & 31 \\
T45 & 60 & 54 & 59 & 45 \\
T60 & 75 & 70 & 70 & 58 \\
T75 & 90 & 83 & 79 & 88 \\
T90 & & & & \\
\hline
\end{tabular}

\subsubsection{Correção e adubação do solo}

Foram realizadas correções nas propriedades químicas do solo e fornecimento de nutrientes a fim de proporcionar, à forragem, condições de expressar potencial produtivo e valor nutritivo adequados, compatível com a exploração proposta. Para tanto, foi efetuada aplicação de $630 \mathrm{~kg} \mathrm{ha}^{-1}$ de calcário dolomítico no dia 03/09/2001. Em 14/11/2001 foram aplicadas doses equivalentes a $170 \mathrm{~kg} \mathrm{ha}^{-1} \mathrm{de} \mathrm{KCl}, 200 \mathrm{~kg} \mathrm{ha}^{-1}$ de Superfosfato simples e $50 \mathrm{~kg}$ $\mathrm{ha}^{-1}$ de micronutrientes (FTE BR-16 ${ }^{\circledR}$ ) em cada parcela. As adubações de cobertura realizadas com auxílio de adubadora pendular marca Vicon ${ }^{\circledR}$ tracionada por trator, estenderam-se entre 14/11/2001 e 13/04/2002 a intervalo de 30 dias com três aplicações da fórmula 30-00-20 na dosagem de $250 \mathrm{~kg}$ $\mathrm{ha}^{-1}$, seguidas de três aplicações da fórmula 20-00-20, na dosagem de $375 \mathrm{~kg}$ $\mathrm{ha}^{-1}$, totalizando $4,50 \mathrm{~kg}$ de $\mathrm{N}$ e $3,75 \mathrm{~kg}$ de $\mathrm{K}_{2} \mathrm{O}$ por parcela $\mathrm{ano}^{-1}$, equivalentes às doses de $450 \mathrm{~kg} \mathrm{~N} \mathrm{ha}^{-1} \mathrm{ano}^{-1}$ e $375 \mathrm{~kg} \mathrm{~K}_{2} \mathrm{O} \mathrm{ha}{ }^{-1} \mathrm{ano}^{-1}$, respectivamente. 


\subsubsection{Calibração: altura do prato $x$ massa de forragem}

Em virtude da impossibilidade da quantificação da massa de forragem em cada corte de cada uma das parcelas procedeu-se a calibração entre altura do prato ("rising plate meter") e massa de forragem dos tratamentos. Foram utilizadas duas áreas quadradas de $1 \mathrm{~m}^{2}$ escolhidas dentro da unidade experimental, procurando áreas representativas de alta e baixa massas de forragem. Essa estratégia de coleta dos dois pontos, contendo limites inferiores e superiores, possibilitou que uma amplitude representativa das combinações entre altura do prato e massa de forragem fosse contemplada e assim, possibilitando a geração de equações mais precisas. Dentro de cada área foi mensurada a altura média do prato e, posteriormente, a forragem foi cortada, manualmente com o auxílio de facas, a uma altura de $5 \mathrm{~cm}$ acima do nível do solo. A forragem total dos quadrados foi pesada e parte seca em estufa de circulação forçada de ar $\left(55^{\circ} \mathrm{C}\right)$ até massa constante. Assim, depois de determinada a massa seca, foi estabelecida, através de regressão linear, utilizando o PROC REG (SAS, 1996), a relação entre altura do prato e massa de forragem do capim-Marandu, baseada em 464 pontos de amostragem durante o período experimental, como demonstra a Equação 2.

$M F=a+b h_{p}$

onde:

$\mathrm{MF} \quad=$ massa de forragem $\left(\mathrm{kg} \mathrm{ha}^{-1}\right)$;

$\mathrm{h}_{\mathrm{p}} \quad=$ altura do prato $(\mathrm{cm})$. 


\subsubsection{Produção de matéria seca}

Através da calibração altura do prato $\mathrm{x}$ massa de forragem (seção 3.2.2.3) foi possível obter a produção de matéria seca do período através da somatória das médias dos cortes de cada tratamento durante o período experimental. Para tanto, foi verificada a altura média do prato de 40 medidas realizadas fora das áreas cortadas nos quadrados de $1 \mathrm{~m}^{2}$, ou seja, nos restantes $98 \mathrm{~m}^{2}$ da parcela. Essa altura média do prato foi àquela utilizada para geração da massa de forragem relativa ao corte em questão.

\subsubsection{Coleta de amostras}

\subsection{Amostragem e amostras}

A amostragem se repetiu com freqüências diferentes nos tratamentos, sendo que o T15 sofreu durante o período experimental 24 cortes, o T30 sofreu 12 cortes, o T45 oito cortes, o T60 seis cortes e o T75 e T90 sofreram quatro cortes durante os 352 dias de experimento.

As amostras da massa de forragem foram coletadas dos cortes realizados nos quadrados de $1 \mathrm{~m}^{2}$. Foram agrupadas as duas massa de forragem (quadrados) da parcela, separadas as frações lâmina foliar $(F)$, haste $(\mathrm{H})$ e material morto (MM), como constituintes da composição morfológica da massa de forragem, e ainda foi obtida uma amostra representando a massa de forragem colhida. Para efeito de uniformização, a bainha foliar foi considerada como parte da fração haste. A massa de tecido vegetal em avançado estágio de senescência foi caracterizada como material morto. Após secagem em estufa de circulação forçada de $\operatorname{ar}\left(55^{\circ} \mathrm{C}\right)$ foram determinadas as proporções de cada componente, as quais foram expressas em porcentagem do peso seco total. 
Posteriormente, prodeceu-se a moagem do material em moinho tipo Willey contra peneira com perfurações de $1 \mathrm{~mm}$ de diâmetro e então, foram identificadas e armazenadas em sacos plásticos para posterior análise.

\subsection{Determinação da composição químico-bromatológica das forragens}

Para determinação da composição químico-bromatológica da forragem foi utilizado o método de espectroscopia de reflectância de infravermelho proximal (NIRS) (Berzaghi et al., 1997 e Cozzolino et al., 2001). O material moído foi escaneado para obtenção dos espectros NIRS. O equipamento utilizado foi o espectrômetro modelo NIRS 5000 (NIRSystems ${ }^{\circledR}$, Silver Spring, MD, USA) acoplado a um microcomputador equipado com software WinISI II versão 6.2 (Intrasoft International, PA), com dois tipos de células de leitura para escanear as amostras: quanto estas apresentavam quantidades suficientes, foi utilizada a célula modelo Transport quarter cup (código IH - 0379), caso contrário, utilizou-se a de modelo Micro sample cup (código IH - 0348).

Um conjunto de 928 amostras foi escaneado nesse equipamento obtendo leituras compreendidas entre comprimentos de onda de 700 a 2100 $\mathrm{nm}$. Esses espectros foram armazenados em curvas log (1/R) em intervalo de 2 $\mathrm{nm}$. Utilizaram-se os métodos de seleção de amostras existentes no software do equipamento e foram descartadas as amostras distantes mais de $3 \mathrm{H}$ (distância padronizada de Mahalanobis) da média, e essas foram tidas com "outliers".

Adotou-se uma distância mínima de 0,6 H entre amostras para seleção daquelas em que seriam efetuadas as análises bromatológicas convencionais (Shenk \& Westerhaus, 1991).

Nas amostras selecionadas foram determinados os teores proteína bruta, obtidos através da combustão das amostras segundo o método de Dumas, utilizando-se um auto-analisador de nitrogênio, marca LECO ${ }^{\circledR}$, modelo FP-528 
(Wiles et al., 1998). As análises dos teores de fibra insolúvel em detergente neutro foram realizadas através do método seqüencial proposto pela ANKOM Fiber Analyser (ANKOM ${ }^{\circledR}$ Technology Corporation, Fairport, NY) e descrito por Holden (1999), assim como a digestibilidade verdadeira in vitro da matéria seca seguindo o mesmo protocolo proposto da ANKOM Fiber Analyser (ANKOM ${ }^{\circledR}$ Technology Corporation, Fairport, NY) e descrito pelo mesmo autor.

O total de amostras selecionadas para análise sob química líquida convencional foi de 163, ou seja, essas foram as amostras somadoras de variação espectral que, após análise e inserção no banco de dados permitiram ao software do programa NIRS predizer o valor das demais amostras não analisadas.

Após a realização dessas análises foram utilizados métodos estatísticos existentes no software do NIRS para o desenvolvimento de equações de predição dos teores dos componentes da análise químico-bromatológica para as 928 amostras.

\subsubsection{Análise estatística dos dados}

Para efeito de análise estatística dos dados estes foram agrupados em ciclos de 90 dias, correspondentes às quatro estações do ano.

Os dados relativos às características agronômicas e valor nutritivo da forragem foram analisados como medidas repetidas no tempo utilizando-se o procedimento MIXED do programa estatístico SAS ${ }^{\circledR}$ (Statistical Analysis System), versão 6.12 para Windows ${ }^{\circledR}$ (SAS, 1996), uma vez que as variáveis foram coletadas ao longo do período experimental e agrupadas em quatro ciclos. Para os dados de produção acumulada de matéria seca e produção de matéria seca digestível no ano, utilizou-se o procedimento GLM do programa estatístico SAS ${ }^{\circledR}$, versão 6.12 para Windows ${ }^{\circledR}$ (SAS, 1996), visto que esses 
dados foram obtidos a partir da somatória dos resultados da produção de matéria seca de cada ciclo (estação do ano).

Para efeito de comparação de médias entre tratamentos foi utilizado o teste de média dos quadrados mínimos (LS MEANS), com nível de significância de $5 \%$.

\subsection{Resultados e Discussão}

\subsubsection{Produção de matéria seca}

Através do PROC REG do SAS (SAS, 1996) obteve-se a Equação 3, descrita abaixo, que expressa a massa de forragem em função da altura do prato:

$M F=304,18+83,31 h_{p}$

com:

C.V. $=34,3 \%$;

$\mathrm{R}^{2}=0,89$;

e onde:

$\mathrm{MF}=$ massa de forragem $\left(\mathrm{kg} \mathrm{ha}^{-1}\right)$;

$\mathrm{h}_{\mathrm{p}} \quad=$ altura do prato $(\mathrm{cm})$;

C.V. = coeficiente de variação;

$\mathrm{R}^{2} \quad$ = coeficiente de determinação.

Os resultados referentes à produção de matéria seca por estação do ano estão apresentados na Tabela 4. Houve efeito do intervalo entre cortes $(P<0,01)$, da estação do ano $(P<0,01)$, bloco $(P<0,01)$ e da interação intervalo 
entre cortes $x$ estação do ano $(P<0,01)$ para a produção de matéria seca por estação do ano. A amplitude dos valores médios de produção de MS ao longo do período experimental foi de 1,3 (T75, inverno) a 13,6 $\mathrm{t}$ ha ${ }^{-1}$ (T60, verão). Com relação ao intervalo entre cortes, maiores produções (acima de 6,4 $\mathrm{t} \mathrm{ha}^{-1}$ ), foram alcançadas nos tratamentos T15, T60, T75 e T90, enquanto que, os tratamentos T30 e T45 diferenciaram-se dos demais e apresentaram menores produções médias nas estações (5,4 e 5,0 t ha ${ }^{-1}$, respectivamente). A Tabela 4 mostra também que o efeito de estação do ano fica evidenciado pelas médias de produção de MS que foram maiores no verão $\left(10,2 \mathrm{t} \mathrm{ha}{ }^{-1}\right)$, seguidas pela de outono $\left(7,0 \mathrm{tha}^{-1}\right)$, primavera $\left(4,3 \mathrm{tha}^{-1}\right)$ e inverno $\left(3,1 \mathrm{t} \mathrm{ha}^{-1}\right)$, respectivamente.

Tabela 4. Produção de matéria seca $\left(\mathrm{t} \mathrm{ha} \mathrm{a}^{-1}\right)$, por estação do ano, do capimMarandu submetido a intervalos entre cortes

\begin{tabular}{lcccccc}
\hline \multirow{2}{*}{ Tratamento } & \multicolumn{5}{c}{ Estação do ano } \\
& Primavera & Verão & Outono & Inverno & Média & \multirow{2}{*}{ EPM $^{*}$} \\
\hline T15 & $5,5^{\mathrm{aB}}$ & $8,4^{\mathrm{deA}}$ & $7,9^{\mathrm{bA}}$ & $5,7^{\mathrm{aB}}$ & $6,9^{\mathrm{a}}$ & 0,19 \\
T30 & $4,2^{\mathrm{bcC}}$ & $7,8^{\mathrm{eA}}$ & $5,8^{\mathrm{cB}}$ & $3,9^{\mathrm{bC}}$ & $5,4^{\mathrm{b}}$ & 0,19 \\
T45 & $3,8^{\mathrm{bcBC}}$ & $9,0^{\mathrm{dA}}$ & $4,6^{\mathrm{dB}}$ & $2,8^{\mathrm{cC}}$ & $5,0^{\mathrm{b}}$ & 0,19 \\
T60 & $4,7^{\mathrm{abC}}$ & $13,6^{\mathrm{aA}}$ & $6,1^{\mathrm{CB}}$ & $2,6^{\mathrm{cdD}}$ & $6,8^{\mathrm{a}}$ & 0,19 \\
T75 & $4,1^{\mathrm{bcC}}$ & $12,4^{\mathrm{bA}}$ & $7,9^{\mathrm{bB}}$ & $1,3^{\mathrm{eD}}$ & $6,4^{\mathrm{a}}$ & 0,19 \\
T90 & $3,7^{\mathrm{cB}}$ & $10,3^{\mathrm{CA}}$ & $9,6^{\mathrm{aA}}$ & $2,1^{\mathrm{dC}}$ & $6,4^{\mathrm{a}}$ & 0,19 \\
Média $^{\mathrm{C}}$ & $4,3^{\mathrm{C}}$ & $10,2^{\mathrm{A}}$ & $7,0^{\mathrm{B}}$ & $3,1^{\mathrm{D}}$ & & \\
EPM $^{*}$ & 0,15 & 0,16 & 0,18 & 0,07 & & \\
\hline
\end{tabular}

*EPM - erro padrão da média.

Médias na linha seguidas de mesmas letras maiúsculas não diferem entre si $(P>0,05)$.

Médias na coluna seguidas de mesmas letras minúsculas não diferem entre si $(P>0,05)$.

Em relação à elevada produção de massa seca encontrada no T15, provavelmente, essa tenha ocorrido em virtude do procedimento de amostragem adotado. Tendo em vista a alta freqüência de corte do referido tratamento (15 dias) associada ao fato de que após o rebaixamento, à altura de 
$5 \mathrm{~cm}$ acima do nível do solo, a parcela era totalmente rastelada e que nem toda a forragem era retirada pode ter havido alguma quantidade de forragem remanescente na parcela, resultando em contaminação e superestimativa do corte subseqüente.

O efeito da estação do ano deve-se, sobretudo, às mudanças que ocorreram durante o ano com relação às variáveis ambientais (Tabela 2), como, principalmente, temperatura, luminosidade e disponibilidade hídrica (precipitação). Esse mesmo efeito foi observado por Gerdes et al. (2000a) que encontraram produções de massa seca de capim-Marandu, quando amostradas aos 35 dias, em um único corte, de $3,76 \mathrm{t} \mathrm{ha}^{-1}$ na primavera, 2,03 $\mathrm{t} \mathrm{ha}^{-1}$ no verão, $1,19 \mathrm{t} \mathrm{ha}^{-1}$ no outono e $0,95 \mathrm{t} \mathrm{ha}^{-1}$ no inverno.

Ao desdobrar os tratamentos dentro das estações do ano na interação entre esses efeitos, observou-se, no outono, a tendência de maiores produções de massa seca observadas nos T15, T60, T75 e T90. No verão, entretanto, uma elevada produção de forragem foi constatada a partir dos 60 dias de intervalo entre cortes e essa tendência seguiu de acordo com a maioria dos trabalhos de literatura (Acunha \& Coelho, 1997; Alvim et al., 1999; Narciso Sobrinho et al.,1998a; Ruggieri et al., 1995 e Singh, 1995). Durante a primavera as maiores produções de MS foram alcançadas nos tratamentos T15 e T60 e a menor ocorreu, surpreendentemente, aos 90 dias de intervalo entre cortes, fato que pode ser justificado pela decapitação do meristema apical no corte de uniformização e possível necessidade de restabelecimento do dossel com base nas reservas orgânicas, num período de déficit hídrico (Tabela 2). Nos cortes de inverno, as maiores produções de MS foram encontradas nos tratamentos onde a forragem foi colhida mais freqüentemente. A baixa produção do T75, nessa estação do ano, foi devida ao corte ter sido finalizado com 56 dias de antecedência do final do experimento. Nos demais tratamentos os cortes foram conduzidos até 18 de julho de 2002, enquanto que o T75 teve sua avaliação terminada em 23 de maio de 2002, visto que se conduzido por mais um corte, 
este não estaria sincronizado com os outros tratamentos e, assim, se prolongaria por, aproximadamente, 19 dias da data final do ensaio.

Os resultados referentes à produção acumulada durante o período experimental estão apresentados na Tabela 5 e na Figura 7. Houve efeito do intervalo entre cortes $(P<0,01)$ e de bloco $(P<0,01)$ quando analisada a produção de matéria seca acumulada durante o ano. A amplitude da produção de MS (t ha-1 ano $^{-1}$ ) ficou entre 20,2 (T45) e 28,2 (T75).

Tabela 5. Produção acumulada de matéria seca do capim-Marandu submetido a intervalos entre cortes, durante 352 dias de período experimental

\begin{tabular}{lcc}
\hline Tratamento & $\begin{array}{c}\text { Produção de MS } \\
\mathrm{t} \mathrm{ha}^{-1}\end{array}$ & EPM* $^{*}$ \\
\hline T15 & $27,5^{\mathrm{a}}$ & 0,86 \\
T30 & $21,7^{\mathrm{b}}$ & 0,86 \\
T45 & $20,2^{\mathrm{b}}$ & 0,86 \\
T60 & $27,0^{\mathrm{a}}$ & 0,86 \\
T75 & $28,2^{\mathrm{a}}$ & 0,86 \\
T90 & $25,7^{\mathrm{a}}$ & 0,86 \\
Média & 25,1 & \\
\hline
\end{tabular}

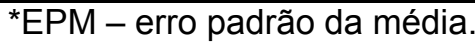

Médias na coluna seguidas de mesmas letras minúsculas não diferem entre si $(P>0,05)$.

Existe a expectativa de incrementos na produção de forragem conforme tivesse aumentado o intervalo entre cortes, conforme observado por diversos autores (Acunha \& Coelho, 1997; Alvim et al., 1999; Costa et al., 1992; Drudi \& Favoretto, 1987; Gomide et al., 1985; Hassan et al., 1990; Narciso Sobrinho et al., 1998a; Ruggieri et al., 1995; Santana \& Santos, 1983; Singh, 1995; Vilela et al., 1978 e Zago \& Gomide, 1982). Contrariando essa tendência, no presente estudo, a elevada produção encontrada no T15 (Tabela 5) foi similar aos tratamentos cortados a intervalos superiores a 60 dias. Essa resposta foi 
justificada pelo esquema de amostragem e regime de cortes adotado que levou ao acúmulo de material residual nos sucessivos cortes. Menores produções associadas a intervalos entre cortes mais curtos são devidas, segundo Brown \& Blaser (1965) e Ward \& Blaser (1961), ao esgotamento dos estoques de reservas orgânicas da planta forrageira comprometendo as sucessivas rebrotações. De acordo com Harris (1978) as reservas são mais importantes quando extremos climáticos de seca ou de baixas temperaturas, por períodos prolongados, reduzem mais intensamente o crescimento.

Outra possível explicação foi apresentada por Zago \& Gomide (1982) que postularam que a maior freqüência de corte reduz a produção de matéria seca devido à decapitação de numerosos perfilhos e que, até a adaptação plástica da comunidade de plantas ocorrer, ela determina a depleção de reservas e o comprometimento da rebrotação subseqüente. Essa teoria foi confirmada pelos resultados do presente estudo. As menores produções acumuladas de MS no ano foram observadas nos tratamentos T30 e T45 e devem-se, possivelmente, à ação de colheita induzir à eliminação do meristema apical, uma vez que, ocorreu possível alongamento das hastes nesses tratamentos (Tabela 7). Essa ocorrência tem especial relevância durante o verão quando a participação das hastes foi mais elevada e também por haver maior partição da energia da planta forrageira para perfilhos reprodutivos. Assim, a rebrotação nesses tratamentos (T30 e T45) ficou dependente da mobilização de reservas orgânicas da base da planta forrageira até o início do restabelecimento da área foliar necessária para o crescimento. A partir dos 60 dias de crescimento vegetativo o capim-Marandu apresentou aumento na produção acumulada de matéria seca, a adequação de um maior período de descanso necessário para restabelecimento da área foliar.

Ferrari Júnior et al. (1994) que estudaram a produção de capim-Marandu submetidos a intervalos entre cortes verificaram efeito quadrático da produção de massa seca o intervalo entre cortes passou de 42 para 84 dias, com máxima produção aos 56 dias de crescimento vegetativo. No presente experimento se 
analisado os intervalos entre cortes próximos aos determinados pelos autores, verifica-se tendência semelhante, embora a máxima produção tenha sido alcançada mais tardiamente, aos 75 dias de crescimento vegetativo.

\subsubsection{Composição morfológica da forragem}

\subsubsection{Porcentagem de folhas}

Os resultados referentes à porcentagem de participação de folhas na massa de forragem seca do capim-Marandu estão apresentados na Tabela 6. Houve efeito do intervalo entre cortes $(P<0,01)$, da estação do ano $(P<0,01)$ e da interação intervalo entre cortes $x$ estação do ano $(P<0,01)$, não tendo sido verificado efeito de bloco $(P=0,39)$. A amplitude da porcentagem de folhas como componente da matéria seca do capim-Marandu foi de 89,4\% (T15 na primavera) a 33,5\% (T90 no verão). Os intervalos entre cortes mais curtos (T15 e T30) apresentaram maior participação de folhas na produção de matéria seca (71,8 e 69,8\%, respectivamente) e à medida que tornaram-se mais espaçados a participação diminuiu, chegando ao mínimo de $52,1 \%$ no T90. Com relação às estações do ano a maior média foi encontrada durante a primavera $(69,6 \%)$, seguida do inverno $(66,8 \%)$ e na seqüência, seguiram-se as de outono e verão que não se diferenciaram entre si (57,7\% e 55,9\%, respectivamente).

No desdobramento dos tratamentos dentro das estações ficou evidenciado, principalmente durante o verão e outono, que ocorreu decréscimo na participação de folhas mediante a extensão do intervalo entre cortes. Durante $o$ inverno a porcentagem de folhas apresentou comportamento inconsistente, porém, foi a estação em que as médias entre tratamentos menos variaram entre si, sendo que a amplitude entre o limite superior e inferior foi de apenas 10,5 unidades percentuais, justificada pelas condições ambientais nas quais a comunidade de plantas foi exposta durante a estação. 
Tabela 6. Porcentagem média de folhas como componente da matéria seca do capim-Marandu submetido a intervalos entre cortes durante as estações do ano

\begin{tabular}{|c|c|c|c|c|c|c|}
\hline \multirow{2}{*}{ Tratamento } & \multicolumn{4}{|c|}{ Estação do ano } & \multirow{2}{*}{ Média } & \multirow{2}{*}{$\mathrm{EPM}^{*}$} \\
\hline & Primavera & Verão & Outono & Inverno & & \\
\hline T15 & $89,4^{\mathrm{aA}}$ & $70,6^{\mathrm{aB}}$ & $62,0^{\mathrm{abc}}$ & $65,3^{\mathrm{abcBC}}$ & $71,8^{\mathrm{a}}$ & 1,19 \\
\hline T30 & $78,7^{\mathrm{bA}}$ & $68,3^{\mathrm{abB}}$ & $67,5^{\mathrm{aB}}$ & $64,8^{\mathrm{bcB}}$ & $69,8^{a}$ & 1,19 \\
\hline $\mathrm{T} 45$ & $63,3^{\mathrm{cA}}$ & $63,0^{\mathrm{bA}}$ & $58,5^{\mathrm{bA}}$ & $64,8^{\mathrm{bcA}}$ & $62,5^{\mathrm{b}}$ & 1,19 \\
\hline T60 & $55,9^{\mathrm{dAB}}$ & $52,5^{\mathrm{cB}}$ & $61,0^{\mathrm{abA}}$ & $61,5^{\mathrm{cA}}$ & $58,1^{\mathrm{c}}$ & 1,19 \\
\hline T75 & $64,5^{\mathrm{cB}}$ & $46,9^{\mathrm{cD}}$ & $55,6^{\mathrm{bC}}$ & $72,0^{\mathrm{aA}}$ & $59,6^{b c}$ & 1,19 \\
\hline T90 & $66,4^{\mathrm{cA}}$ & $33,5^{\mathrm{dC}}$ & $40,9^{c B}$ & $67,6^{\mathrm{abA}}$ & $52,1^{d}$ & 1,19 \\
\hline Média & $69,6^{A}$ & $55,9^{C}$ & $57,7^{\mathrm{C}}$ & $66,8^{\mathrm{B}}$ & & \\
\hline EPM $^{*}$ & 0,97 & 0,97 & 0,97 & 0,97 & & \\
\hline
\end{tabular}

*EPM - erro padrão da média.

Médias na linha seguidas de mesmas letras maiúsculas não diferem entre si $(P>0,05)$.

Médias na coluna seguidas de mesmas letras minúsculas não diferem entre si $(P>0,05)$.

Em relação à porcentagem de folhas observada nas estações do ano, Gerdes et al. (2000a), em capim-Marandu, relataram que nas estações de primavera e verão as porcentagens desse componente foram inferiores àquelas encontradas nas outras estações, de outono e inverno. Santos (1997) justifica a baixa porcentagem de folhas na estação como sendo conseqüência da predominância de perfilhos reprodutivos no período, e isso seria a possível explicação para os resultados encontrados no presente trabalho.

Com relação ao intervalo entre cortes, os resultados encontrados neste trabalho corroboram com aqueles obtidos por diversos autores (Acunha \& Coelho, 1997; Borges et al., 2002; Ferrari Júnior et al., 1994; Narciso Sobrinho et al., 1998a e Ruggieri et al., 1994) que sugerem redução na participação de folhas na composição da MS como resposta aos aumentos no intervalo entre cortes da forragem. 


\subsubsection{Porcentagem de hastes}

Os resultados referentes à porcentagem de participação das hastes na produção de matéria seca da forragem estão apresentados na Tabela 7. Houve efeito do intervalo entre cortes $(P<0,01)$, da estação do ano $(P<0,01)$ e da interação intervalo entre cortes $x$ estação do ano $(P<0,01)$, não tendo sido verificado efeito de bloco $(P=0,20)$. A amplitude dos valores esteve situada entre $7,6 \%$ (T15 na primavera) e 56,4\% (T90 no verão) e, como esperado, exatamente em oposição à porcentagem de folhas e discutida no item anterior. Todos os tratamentos diferenciaram-se entre si e mostraram tendência de aumento do percentual de hastes conforme o estádio de maturidade avançou; a contribuição das hastes na produção de MS variou entre 14,2\% (T15) e 37,0\% (T90). Em função das estações do ano a participação das hastes na massa de MS do capim-Marandu seguiu a seguinte ordem crescente: inverno $(13,2 \%)$, primavera $(20,7 \%)$, outono $(29,1 \%)$ e verão $(37,7 \%)$.

A exploração do desdobramento do efeito da interação intervalo entre cortes $x$ estação do ano revelou o efeito do tratamento dentro das estações do ano caracterizando-se, consistentemente, aumento no percentual das hastes à medida que o intervalo entre cortes foi estendido em três das quatro estações (primavera, verão e outono). Porém, esse efeito não foi verificado durante o corte de inverno, sobretudo em virtude do valor encontrado no T90 ter siso menor que àquele obtido no T75.

Assim, como para a porcentagem de folhas, durante o inverno houve a menor variação entre os tratamentos na porcentagem de hastes (10 unidades percentuais), possivelmente em função de alterações ambientais intrínsecas à estação, determinando menor ritmo de crescimento da forragem.

Em experimento utilizando capim-Marandu em oito idades de rebrotação, Borges et al. (2002) verificaram uma tendência semelhante à obtida neste experimento, sendo que até os 56 dias de rebrotação não foi verificada presença de hastes na forragem cortada a $20 \mathrm{~cm}$ de altura. Contudo, dos 70 
aos 126 dias de rebrotação, houve aumento crescente da participação de hastes na massa total de MS. Dados semelhantes foram observados por Acunha \& Coelho (1997) em estudo com capim-elefante submetido a idades de rebrotação e a alturas de corte. Nesse estudo houve aumento da participação das hastes na produção de MS com o aumentou do intervalo entre cortes, independentemente da altura de corte estudada. Também Narciso Sobrinho et al. (1998a) e Ferrari Júnior et al. (1994) encontraram efeito similar ao previamente relatado.

Tabela 7. Porcentagem média de hastes como componente da matéria seca do capim-Marandu submetido a intervalos entre cortes durante as estações do ano

\begin{tabular}{|c|c|c|c|c|c|c|}
\hline \multirow{2}{*}{ Tratamento } & \multicolumn{4}{|c|}{ Estação do ano } & \multirow{2}{*}{ Média } & \multirow{2}{*}{$\mathrm{EPM}^{*}$} \\
\hline & Primavera & Verão & Outono & Inverno & & \\
\hline T15 & $7,6^{\mathrm{CB}}$ & $20,2^{\mathrm{fA}}$ & $20,0^{\mathrm{dA}}$ & $9,0^{\mathrm{CB}}$ & $14,2^{f}$ & 0,92 \\
\hline T30 & $14,3^{\mathrm{bcBC}}$ & $23,2^{\mathrm{eA}}$ & $19,5^{\mathrm{dB}}$ & $11,1^{\mathrm{cC}}$ & $17,8^{\mathrm{e}}$ & 0,92 \\
\hline T45 & $16,7^{\mathrm{bcB}}$ & $32,5^{\mathrm{dA}}$ & $26,5^{\mathrm{cB}}$ & $11,7^{\mathrm{bcc}}$ & $21,8^{d}$ & 0,92 \\
\hline T60 & $26,8^{a B}$ & $43,0^{\mathrm{cA}}$ & $27,5^{\mathrm{cB}}$ & $14,7^{\mathrm{bC}}$ & $28,5^{c}$ & 0,92 \\
\hline T75 & $27,8^{\mathrm{aC}}$ & $48,1^{\mathrm{bA}}$ & $34,2^{\mathrm{bB}}$ & $19,0^{\mathrm{aD}}$ & $32,3^{b}$ & 0,92 \\
\hline T90 & $30,51^{\mathrm{ac}}$ & $56,4^{\mathrm{aA}}$ & $47,4^{\mathrm{aB}}$ & $13,7^{\mathrm{bcD}}$ & $37,0^{\mathrm{a}}$ & 0,92 \\
\hline Média & $20,7^{\mathrm{C}}$ & $37,7^{A}$ & $29,1^{\mathrm{B}}$ & $13,2^{\mathrm{D}}$ & & \\
\hline EPM $^{*}$ & 1,07 & 0,70 & 0,59 & 0,53 & & \\
\hline
\end{tabular}

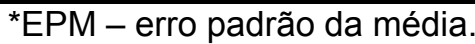

Médias na linha seguidas de mesmas letras maiúsculas não diferem entre si $(P>0,05)$.

Médias na coluna seguidas de mesmas letras minúsculas não diferem entre si $(P>0,05)$.

A maior proporção de hastes na forragem produzida, com maiores intervalos entre cortes, deve ter ocorrido em virtude da mudança da qualidade e quantidade da luz que chegou até a base da planta, pois, segundo Lemaire \& Chapman (1996), a luz que chega ao ápice do dossel forrageiro é refratada e sofre modificações na sua qualidade alterando o comprimento de onda da luz 
visível. A luz predominante no micro-ambiente interior do dossel é a infravermelha ( $\lambda \leq 730 \mathrm{~nm}$ ), a qual, de acordo com Ludlow (1978), promove, mais especificamente, alongamento das hastes.

\subsubsection{Porcentagem de material morto}

Os resultados referentes à porcentagem de participação do material morto na massa seca de forragem do capim-Marandu estão apresentados na Tabela 8. Houve efeito do intervalo entre cortes $(P<0,01)$, da estação do ano $(P<0,01)$ e da interação intervalo entre cortes $x$ estação do ano $(P<0,01)$, não tendo sido verificado efeito de bloco $(P=0,74)$. $O$ maior valor percentual de material morto foi encontrado no T15 de inverno $(25,7 \%)$ e o menor foi encontrado no T15 e T90 de primavera $(3,0 \%)$. Nos diferentes intervalos entre cortes, pode-se notar uma pequena variação ocorrida na porcentagem de material morto, entretanto sem tendência consistente. Com relação às estações do ano $20,3 \%$ de material morto foi encontrado durante o inverno, $13,2 \%$ no outono, $9,7 \%$ na primavera e, finalmente, $6,4 \%$ no verão.

Era de se esperar que nos tratamentos em que o intervalo entre cortes foi maior houvesse maior porcentagem de material morto contribuindo para a produção de MS, isso ocorre em diversas espécies de forragens, e, segundo Corsi et al. (1994), o capim-Marandu levaria em torno de 30 a 35 dias para completar seu ciclo vegetativo, portanto acima do T45 seria o limite para início da senescência das primeiras folhas dos perfilhos. Essa teoria foi comprovada por Narciso Sobrinho et al. (1998a), em capim-elefante, os autores relataram aumentos percentuais na participação do material morto na massa de forragem de 3,6, 6,5 e 8,8\% conforme a idade de rebrotação estudada variou de 56 para 70 e 86 dias, respectivamente.

Contrariando os relatos de Narciso Sobrinho et al. (1998a) no presente estudo não se verificou essa tendência, sendo encontrados valores mais elevados no T15, idade na qual, teoricamente, o capim-Marandu não teria 
completado seu ciclo, principalmente nas estações de outono e inverno. Esses valores mais elevados encontrados no T15 não condizem com os resultados de literatura e devem-se, provavelmente, ao método de colheita do material que foi, constantemente, submetido à ceifa e que, por isso, recebeu sistematicamente a contribuição de forragem residual das colheitas anteriores.

Tabela 8. Porcentagem média de material morto como componente da matéria seca do capim-Marandu submetido a intervalos entre cortes durante as estações do ano

\begin{tabular}{|c|c|c|c|c|c|c|}
\hline \multirow{2}{*}{ Tratamento } & \multicolumn{4}{|c|}{ Estação do ano } & \multirow{2}{*}{ Média } & \multirow{2}{*}{ EPM $^{*}$} \\
\hline & Primavera & Verão & Outono & Inverno & & \\
\hline T15 & $3,0^{\mathrm{bD}}$ & $9,2^{\mathrm{aC}}$ & $18,0^{\mathrm{aB}}$ & $25,7^{\mathrm{aA}}$ & $14,0^{\mathrm{ab}}$ & 0,96 \\
\hline T30 & $7,0^{\mathrm{bC}}$ & $5,5^{\mathrm{bC}}$ & $13,0^{\mathrm{bcB}}$ & $24,1^{\mathrm{abA}}$ & $12,4^{\mathrm{bc}}$ & 0,96 \\
\hline $\mathrm{T} 45$ & $20,0^{\mathrm{aAB}}$ & $4,5^{\mathrm{bC}}$ & $15,0^{\mathrm{abB}}$ & $23,5^{\mathrm{abA}}$ & $15,7^{a}$ & 0,96 \\
\hline T60 & $17,3^{\mathrm{aA}}$ & $4,5^{\mathrm{bC}}$ & $11,5^{\mathrm{bcB}}$ & $20,0^{\mathrm{abA}}$ & $13,4^{\mathrm{abc}}$ & 0,96 \\
\hline $\mathrm{T} 75$ & $7,7^{\mathrm{bAB}}$ & $5,0^{\mathrm{bB}}$ & $10,2^{\mathrm{cA}}$ & $9,0^{\mathrm{CAB}}$ & $8,1^{d}$ & 0,96 \\
\hline T90 & $3,0^{\mathrm{bC}}$ & $10,0^{\mathrm{aB}}$ & $11,7^{\mathrm{bcB}}$ & $18,7^{\mathrm{bA}}$ & $10,9^{\text {cd }}$ & 0,96 \\
\hline Média & $9,7^{\mathrm{C}}$ & $6,4^{\mathrm{D}}$ & $13,2^{\mathrm{B}}$ & $20,3^{A}$ & & \\
\hline EPM $^{*}$ & 0,99 & 0,50 & 0,59 & 0,86 & & \\
\hline
\end{tabular}

*EPM - erro padrão da média.

Médias na linha seguidas de mesmas letras maiúsculas não diferem entre si $(P>0,05)$.

Médias na coluna seguidas de mesmas letras minúsculas não diferem entre si $(P>0,05)$.

Isso pode ser justificado a partir dos dados de Corsi et al. (1994) que encontraram para capim-Marandu, número de folhas verdes por perfilho variando de 5 a 7 e taxa de aparecimento de folhas por perfilho de 0,15 a 0,19 folhas dia $^{-1}$, necessitando, portanto, de cerca de cinco dias para expansão completa de uma folha. Assim sendo, em média, a cada 30-35 dias a forragem completaria seu ciclo de desenvolvimento, e, a partir de então, com o início da expansão da próxima folha, iniciar-se-ia a senescência da primeira folha expandida. 


\subsubsection{Relação folha/haste}

Os resultados referentes à relação $\mathrm{F}: \mathrm{H}$ da forragem estão apresentados na Tabela 9 e Figura 3. Houve efeito do intervalo entre cortes $(P<0,01)$, da estação do ano $(P<0,01)$ e da interação intervalo entre cortes $x$ estação do ano $(P<0,01)$, não tendo sido verificado efeito de bloco $(P=0,06)$. A relação $F: H$ apresentou amplitude variando entre 0,6 (T90, verão) e 13,1 (T15, primavera). A relação diminuiu progressivamente conforme o intervalo entre cortes aumentou até, aproximadamente, 60 dias, ponto a partir do qual se estabilizou. Nas estações do ano, maiores valores na relação foram encontrados durante o inverno e na primavera (5,2 e 5,0, respectivamente), seguidas pelo outono $(2,3)$ e atingindo a menor relação $\mathrm{F}: \mathrm{H}$ durante os cortes de verão $(1,8)$.

Tabela 9. Relação folha/haste média do capim-Marandu submetido a intervalos entre cortes durante as estações do ano

\begin{tabular}{|c|c|c|c|c|c|c|}
\hline \multirow{2}{*}{ Tratamento } & \multicolumn{4}{|c|}{ Estação do ano } & \multirow{2}{*}{ Média } & \multirow{2}{*}{$\mathrm{EPM}^{*}$} \\
\hline & Primavera & Verão & Outono & Inverno & & \\
\hline T15 & $13,1^{\mathrm{aA}}$ & $3,5^{\mathrm{aC}}$ & $3,1^{a C}$ & $7,3^{\mathrm{aB}}$ & $6,8^{a}$ & 0,26 \\
\hline T30 & $5,9^{\mathrm{bA}}$ & $2,7^{\mathrm{bC}}$ & $3,5^{\mathrm{aB}}$ & $5,8^{\mathrm{bA}}$ & $4,5^{\mathrm{b}}$ & 0,26 \\
\hline T45 & $4,1^{\mathrm{bcAB}}$ & $2,0^{\mathrm{cB}}$ & $2,2^{\mathrm{bB}}$ & $5,7^{\mathrm{bA}}$ & $3,5^{\mathrm{c}}$ & 0,26 \\
\hline T60 & $2,2^{\mathrm{CAB}}$ & $1,2^{\mathrm{dB}}$ & $2,4^{\mathrm{bA}}$ & $3,4^{\mathrm{CA}}$ & $2,3^{d}$ & 0,26 \\
\hline T75 & $2,5^{\mathrm{cAB}}$ & $1,0^{\mathrm{deB}}$ & $1,6^{\mathrm{CB}}$ & $3,9^{\mathrm{cA}}$ & $2,2^{d}$ & 0,26 \\
\hline T90 & $2,2^{\mathrm{cB}}$ & $0,6^{\mathrm{eB}}$ & $0,9^{\mathrm{dB}}$ & $5,2^{\mathrm{bA}}$ & $2,2^{d}$ & 0,26 \\
\hline Média & $5,0^{\mathrm{A}}$ & $1,8^{\mathrm{C}}$ & $2,3^{\mathrm{B}}$ & $5,2^{\mathrm{A}}$ & & \\
\hline EPM $^{*}$ & 0,41 & 0,07 & 0,08 & 0,18 & & \\
\hline
\end{tabular}

*EPM - erro padrão da média.

Médias na linha seguidas de mesmas letras maiúsculas não diferem entre si $(P>0,05)$.

Médias na coluna seguidas de mesmas letras minúsculas não diferem entre si $(P>0,05)$.

O desdobramento dos tratamentos dentro das estações do ano permitiu verificar que a tendência observada nas médias dos tratamentos também foi 
encontrada em cada estação. Os resultados concordam com os dados obtidos por Garcia \& Silva (1980). De acordo com Pinto et al. (1994), a elevada relação F:H confere à gramínea uma melhor adaptação ao pastejo ou tolerância ao corte, representando um momento de desenvolvimento fisiológico em que os meristemas apicais se apresentam mais próximos do nível do solo. Entretanto, exceção deve ser feita à alta relação $\mathrm{F}: \mathrm{H}$ no T90 de inverno, conseqüência da baixa porcentagem de haste (Tabela 7) no referido tratamento durante 0 período de baixas temperaturas e déficit hídrico.

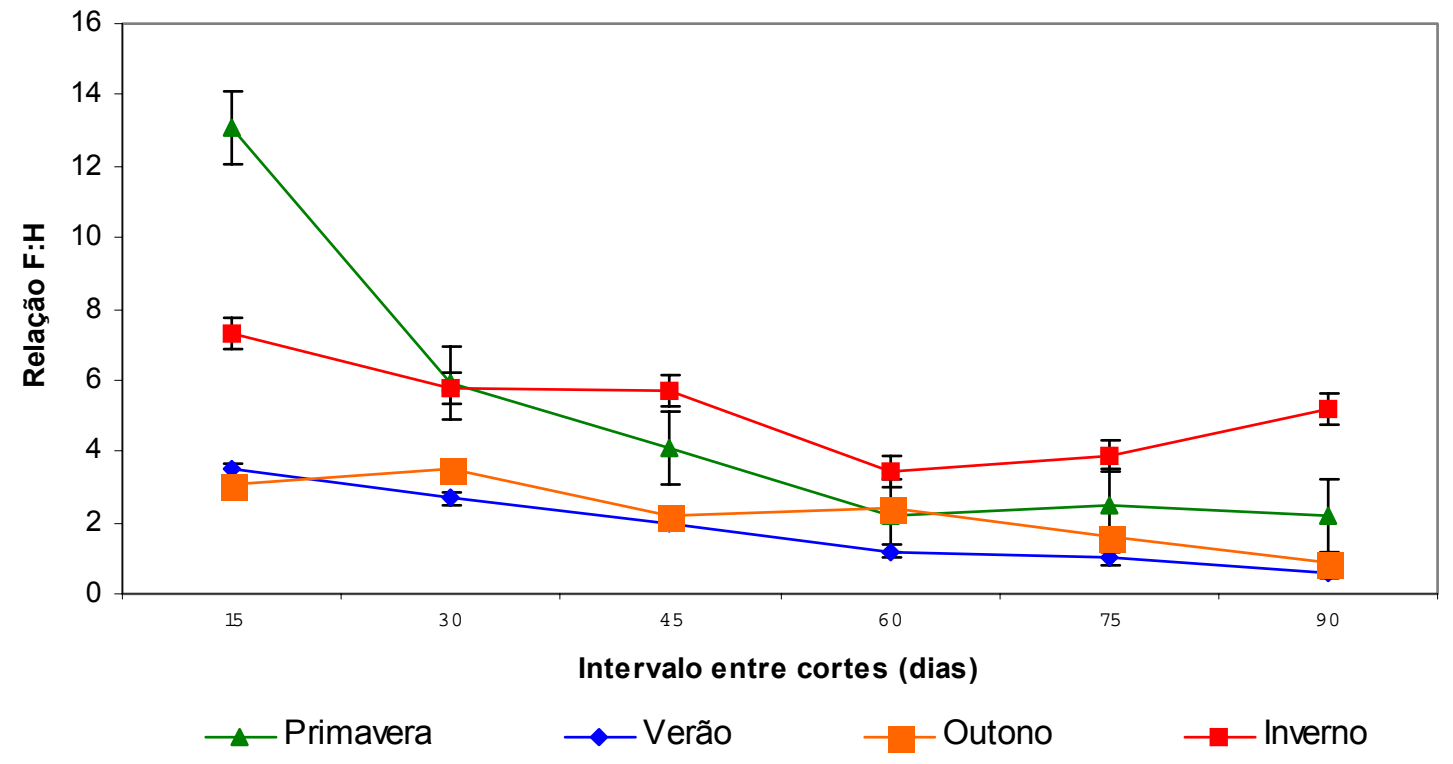

Figura 3 - Variação da relação folha/haste do capim-Marandu em função do intervalo entre cortes, nas estações do ano

Os valores médios da relação $\mathrm{F}: \mathrm{H}$ encontrados nas estações do ano neste estudo seguem o modelo encontrado por Santos et al. (1999), que, trabalhando com capim-Mombaça (Panicum maximum cv. Mombaça) sob pastejo, encontraram tendência decrescente da relação F:H no decorrer da 
transição da primavera para o outono, passando de 1,87 no período de $14 / 11$ a 31/12/95, para 0,71 no período compreendido entre 6/4 e 23/5/95.

Para Pinto et al. (1994), a relação F:H deveria ser maior ou igual a 1 indicando uma participação significativa de folhas na massa de forragem, com provável aumento do valor nutritivo. Isso posto, verificou-se no presente trabalho que os dois únicos momentos em que essa relação não foi atendida restringiram-se aos tratamentos T90 de verão e outono (Tabela 9 e Figura 3), resultantes de baixas porcentagens de folha concomitantes à elevada participação de hastes.

Na Figura 3 observa-se o efeito da relação F:H em função do intervalo entre cortes e nota-se que a forragem, durante o inverno, apresentou variação menos acentuada dessa relação para os tratamentos estudados.

\subsubsection{Composição químico-bromatológica da forragem}

\subsubsection{Teor de matéria seca da forragem}

Os resultados referentes ao teor médio de matéria seca da forragem estão apresentados na Tabela 10. Houve efeito do intervalo entre cortes $(P<0,01)$, da estação do ano $(P<0,01)$ e da interação intervalo entre cortes $x$ estação do ano $(P<0,01)$, não tendo sido verificado efeito de bloco $(P=0,36)$. $A$ amplitude dos teores de MS esteve entre 30,4\% (T90 no outono) e 18,5\% (T60 no verão). $O$ intervalo entre cortes não apresentou comportamento consistente em relação ao teor de MS. Todavia, o efeito das estações do ano sobre o teor de MS determinou comportamento melhor estabelecido, uma vez que o maior teor de MS foi encontrado durante o inverno $(26,6 \%)$, seguido dos teores durante o outono e primavera ( $24,6 \%$ cada) e, sendo o menor valor observado durante o verão $(19,4 \%)$.

No desdobramento dos tratamentos dentro das estações verificou-se que a mesma inconsistência ocorreu, não sendo possível estabelecer nenhuma 
tendência entre valores. Apesar disso, inúmeros trabalhos mostraram que, conforme distanciam-se os cortes, o teor de MS tende a aumentar, a saber: Drudi \& Favoretto (1987); Lavezzo et al. (1980); Nunes et al. (1985) e Rolim (1976).

Tabela 10. Teor médio de matéria seca (\%) do capim-Marandu submetido a intervalo entre cortes durante as estações do ano

\begin{tabular}{|c|c|c|c|c|c|c|}
\hline \multirow{2}{*}{ Tratamento } & \multicolumn{4}{|c|}{ Estação do ano } & \multirow{2}{*}{ Média } & \multirow{2}{*}{ EPM $^{*}$} \\
\hline & Primavera & Verão & Outono & Inverno & & \\
\hline T15 & $22,9^{\mathrm{CAB}}$ & $18,8^{\mathrm{bC}}$ & $22,7^{\mathrm{bB}}$ & $25,6^{\mathrm{bA}}$ & $22,5^{\mathrm{C}}$ & 0,57 \\
\hline T30 & $25,1^{\text {bcA }}$ & $19,1^{\mathrm{bC}}$ & $21,7^{\mathrm{bB}}$ & $25,0^{\mathrm{bA}}$ & $22,7^{\mathrm{c}}$ & 0,57 \\
\hline T45 & $28,2^{\mathrm{aA}}$ & $18,9^{\mathrm{bB}}$ & $29,2^{\mathrm{aA}}$ & $28,4^{\mathrm{aA}}$ & $26,4^{\mathrm{a}}$ & 0,57 \\
\hline T60 & $25,9^{\mathrm{bB}}$ & $18,5^{\mathrm{bC}}$ & $20,5^{\mathrm{bC}}$ & $29,8^{\mathrm{aA}}$ & $23,7^{b c}$ & 0,57 \\
\hline T75 & $24,6^{\mathrm{bA}}$ & $21,4^{\mathrm{aA}}$ & $23,0^{\mathrm{bA}}$ & $22,1^{\mathrm{cA}}$ & $22,8^{\mathrm{C}}$ & 0,57 \\
\hline Т90 & $19,9^{\mathrm{dB}}$ & $19,7^{\mathrm{bB}}$ & $30,4^{\mathrm{aA}}$ & $29,1^{\mathrm{aA}}$ & $24,8^{a b}$ & 0,57 \\
\hline Média & $24,6^{\mathrm{B}}$ & $19,4^{\mathrm{C}}$ & $24,6^{\mathrm{B}}$ & $26,6^{\mathrm{A}}$ & & \\
\hline EPM $^{*}$ & 0,42 & 0,22 & 0,50 & 0,38 & & \\
\hline
\end{tabular}

*EPM - erro padrão da média.

Médias na linha seguidas de mesmas letras maiúsculas não diferem entre si $(P>0,05)$.

Médias na coluna seguidas de mesmas letras minúsculas não diferem entre si $(P>0,05)$.

Os teores médios de MS neste trabalho apresentaram valores superiores aos encontrados por Acunha \& Coelho (1997) e Ferrari Júnior et al. (1994) na mesma espécie e em idades de rebrotação similares e, menores que os relatados, em capim-Marandu, por Borges et al. (2002) também com intervalos entre cortes semelhantes.

No que diz respeito às estações do ano, Gerdes et al. (2000a) obtiveram maiores teores de MS no verão e inverno que os de primavera e outono. No presente estudo apenas o teor médio de MS de verão foi menor que o encontrado pelos autores mencionados, sendo, nas demais estações do ano superiores aos teores relatados por Gerdes et al. (2000a). 


\subsubsection{Teor de proteína bruta da forragem}

Os resultados referentes ao teor médio de proteína bruta da forragem estão apresentados na Tabela 11 e Figura 4. Houve efeito do intervalo entre cortes $(P<0,01)$, da interação intervalo entre cortes $x$ estação do ano $(P<0,01)$ e de bloco $(P<0,05)$, não tendo sido verificado efeito da estação do ano $(P=0,32)$. A amplitude dos teores de PB situou-se entre 6,7\% (T90 de verão) e 13,5\% (T15 de primavera e T30 de outono). O teor de PB diminuiu de 13,3\% (T15) para 8,9\% (T90) à medida que o intervalo entre cortes aumentou. Com relação às estações do ano, não houve diferença entre os tratamentos, situando-se as médias entre 10,4 e 10,9\% PB.

Tabela 11. Teor médio de proteína bruta (\% MS) do capim-Marandu submetido a intervalos entre cortes durante as estações do ano

\begin{tabular}{|c|c|c|c|c|c|c|}
\hline \multirow{2}{*}{ Tratamento } & \multicolumn{4}{|c|}{ Estação do ano } & \multirow{2}{*}{ Média } & \multirow{2}{*}{$\mathrm{EPM}^{*}$} \\
\hline & Primavera & Verão & Outono & Inverno & & \\
\hline T15 & $13,5^{\mathrm{aA}}$ & $13,2^{\mathrm{aA}}$ & $12,5^{\mathrm{aA}}$ & $13,8^{\mathrm{aA}}$ & $13,3^{\mathrm{a}}$ & 0,25 \\
\hline T30 & $10,1^{\mathrm{cC}}$ & $12,5^{\mathrm{abAB}}$ & $13,5^{\mathrm{aA}}$ & $12,0^{\mathrm{bB}}$ & $12,0^{b}$ & 0,25 \\
\hline $\mathrm{T} 45$ & $11,2 b^{b c A B}$ & $11,6^{\mathrm{bA}}$ & $10,2^{\mathrm{bAB}}$ & $9,8^{\mathrm{CB}}$ & $10,7^{c}$ & 0,25 \\
\hline T60 & $8,0^{\mathrm{dA}}$ & $9,6^{\mathrm{cA}}$ & $9,7^{\mathrm{bA}}$ & $8,7^{\mathrm{CA}}$ & $9,0^{d}$ & 0,25 \\
\hline T75 & $8,4^{\mathrm{dC}}$ & $8,5^{\mathrm{cC}}$ & $10,2^{\mathrm{bB}}$ & $12,5^{\mathrm{abA}}$ & $9,9^{c}$ & 0,25 \\
\hline T90 & $12,3^{\mathrm{abA}}$ & $6,7^{\mathrm{dC}}$ & $7,7^{\mathrm{cBC}}$ & $8,7^{\mathrm{CB}}$ & $8,9^{d}$ & 0,25 \\
\hline Média & $10,6^{A}$ & $10,4^{A}$ & $10,6^{A}$ & $10,9^{A}$ & & \\
\hline EPM $^{*}$ & 0,21 & 0,21 & 0,21 & 0,21 & & \\
\hline
\end{tabular}

*EPM - erro padrão da média.

Médias na linha seguidas de mesmas letras maiúsculas não diferem entre si $(P>0,05)$.

Médias na coluna seguidas de mesmas letras minúsculas não diferem entre si $(P>0,05)$.

A análise de tratamento dentro das estações do ano revelou que a tendência de redução do teor de PB com o avanço da maturidade da forragem se repetiu nas estações de verão, outono e inverno. Esse comportamento era 
esperado e concorda com os encontrados por Acunha \& Coelho (1997); Andrade et al. (1994); Drudi \& Favoretto (1987); Lavezzo et al. (1980); Narciso Sobrinho et al. (1998a); Santana \& Santos (1983) e Silveira et al. (1974). Os elevados teores observados para PB nos tratamentos onde a forragem foi colhida em estádio vegetativo inicial, provavelmente, devem-se às elevadas porcentagens de folhas (Tabela 6 ) e baixas porcentagens de haste (Tabela 7), além da conseqüente elevada relação F:H (Tabela 9). Pois, segundo vários autores (Moura et al. 1975; Rodrigues \& Blanco, 1970 e Santana et al., 1989), as folhas são notadamente mais digestíveis e nutricionalmente mais ricas, como observado por El-Memari Neto et al. (2002) que encontraram teores médios de PB nas folhas de $11,6 \%$ e 5,5\% nas hastes de capim-Marandu.

Durante a primavera os teores de PB não seguiram a tendência das outras estações, provavelmente, por ter sido a primeira estação a ser amostrada e, também, porque no início do experimento o dossel ainda não havia se adaptado ao regime de cortes.

Também deve-se ressaltar que o alto teor de PB encontrado no T75 de inverno, deve-se, possivelmente, à antecipação do término da avaliação nesse tratamento, conforme descrito na seção 3.3.1. Com isso, esse tratamento foi poupado em 56 dias do crescimento, durante o inverno seco, conseguindo manter um maior teor de $\mathrm{PB}$, em decorrência de um crescimento que se iniciou durante o início do outono, em meados de março de 2002, quando a precipitação foi uma das mais elevadas dentro do período experimental com 274,6 mm (Tabela 2). O alto teor de PB no T75 de inverno teve conseqüência sobre o valor médio do tratamento T75 (9,9\% MS) o qual foi maior que o esperado, visto não seguir a tendência de diminuição com o aumento do intervalo entre cortes. Seria esperado um valor inferior a 9,0\% PB na MS, pois nos tratamentos T60 e T90 os valores encontrados foram de 9,0 e 8,9\%, respectivamente. 


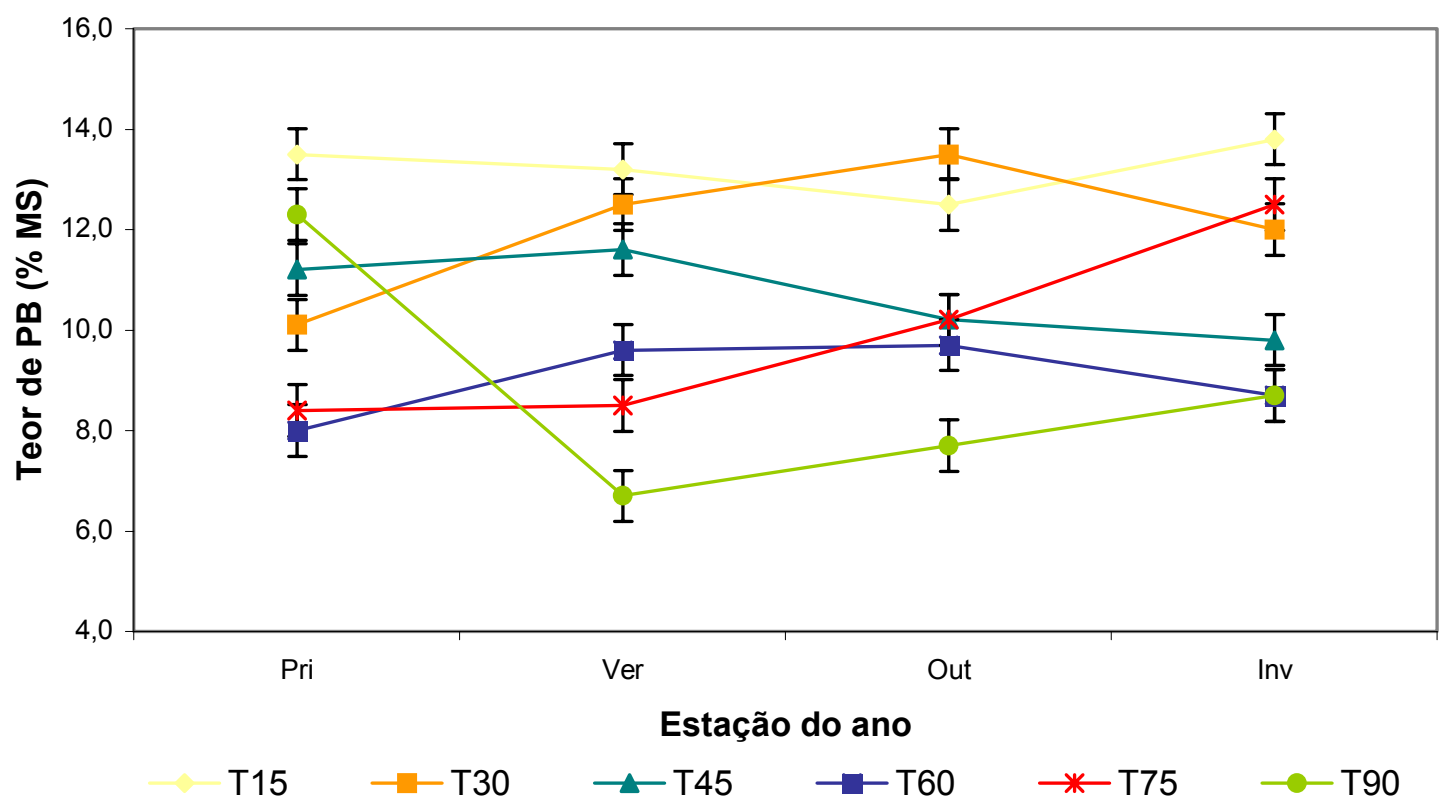

Figura 4 - Variação estacional dos teores de proteína bruta nos diferentes intervalos entre cortes em capim-Marandu

Os teores médios, nas estações do ano, não variaram neste trabalho, porém Gerdes et al. (2000b) encontraram valores distintos entre as estações seguindo outono, inverno, primavera e verão, com teores médios de 18,6, 13,7, 12,8 e $11,4 \%$ PB na MS, respectivamente, valores mais elevados que os do presente estudo, ainda que os autores tenham colhido forragens com 35 dias de rebrotação em um único corte por estação.

\subsubsection{Teor de fibra insolúvel em detergente neutro da forragem}

Os resultados referentes ao teor médio de FDN da forragem estão apresentados na Tabela 12 e Figura 5. Houve efeito do intervalo entre cortes $(P<0,01)$, da estação do ano $(P<0,01)$, de bloco $(P<0,01)$ e da interação intervalo entre cortes $x$ estação do ano $(P<0,01)$. Os teores de FDN variaram de $63,3 \%$ (T90 de inverno) a 77,6\% (T90 de verão). Houve tendência de aumento 
do teor de FDN conforme houve maturação da forragem, nesse caso representada pela maior extensão do intervalo entre cortes, sendo que o teor de FDN aumentou até os 60 dias de intervalo entre cortes, tornando-se constante a partir desse ponto. Com relação às estações, o teor de FDN foi mais elevado no verão (72,1\% FDN), seguido das estações de outono (69,4\% FDN) e de inverno $(69,2 \%$ FDN), que não diferenciaram-se entre si, sendo o menor teor encontrado nos cortes de inverno (64,9\% FDN).

Tabela 12. Teor médio de fibra insolúvel em detergente neutro (\% MS) do capim-Marandu submetido a intervalos entre cortes durante as estações do ano

\begin{tabular}{|c|c|c|c|c|c|c|}
\hline \multirow{2}{*}{ Tratamento } & \multicolumn{4}{|c|}{ Estação do ano } & \multirow{2}{*}{ Média } & \multirow{2}{*}{$\mathrm{EPM}^{*}$} \\
\hline & Primavera & Verão & Outono & Inverno & & \\
\hline T15 & $66,3^{\mathrm{CB}}$ & $68,8^{\mathrm{dA}}$ & $68,1^{\text {cdA }}$ & $64,1^{\mathrm{bcC}}$ & $66,8^{c}$ & 0,29 \\
\hline T30 & $69,8^{\mathrm{abA}}$ & $68,4^{\mathrm{dA}}$ & $66,7^{\mathrm{dB}}$ & $64,7^{\mathrm{abcc}}$ & $67,4^{c}$ & 0,29 \\
\hline $\mathrm{T} 45$ & $69,5^{\mathrm{abA}}$ & $70,5^{\mathrm{cA}}$ & $69,2^{\mathrm{dcA}}$ & $65,2^{\mathrm{abB}}$ & $68,6^{b}$ & 0,29 \\
\hline T60 & $70,4^{\mathrm{ab}}$ & $73,0^{\mathrm{bA}}$ & $70,0^{\mathrm{bB}}$ & $66,0^{\mathrm{aC}}$ & $69,8^{a}$ & 0,29 \\
\hline $\mathrm{T} 75$ & $70,4^{\mathrm{aB}}$ & $74,1^{\mathrm{bA}}$ & $70,1^{\mathrm{bB}}$ & $66,0^{\mathrm{aC}}$ & $70,2^{a}$ & 0,29 \\
\hline T90 & $68,5^{\mathrm{bc}}$ & $77,6^{\mathrm{aA}}$ & $72,1^{\mathrm{aB}}$ & $63,3^{\mathrm{cD}}$ & $70,4^{a}$ & 0,29 \\
\hline Média & $69,2^{\mathrm{B}}$ & $72,1^{\mathrm{A}}$ & $69,4^{\mathrm{B}}$ & $64,9^{\mathrm{C}}$ & & \\
\hline EPM $^{*}$ & 0,24 & 0,24 & 0,24 & 0,24 & & \\
\hline
\end{tabular}

*EPM - erro padrão da média.

Médias na linha seguidas de mesmas letras maiúsculas não diferem entre si $(P>0,05)$.

Médias na coluna seguidas de mesmas letras minúsculas não diferem entre si $(P>0,05)$.

No desdobramento dos tratamentos dentro das estações pôde-se observar que a tendência de maiores teores de FDN nos intervalos entre cortes mais longos se repetiu nas estações de verão e outono. Dentro das estações de primavera e inverno, entretanto, não foi constatada essa tendência, apesar do corte de inverno apresentar a menor variação dentre as estações. 
Forragens mais maduras com teores mais elevados de FDN foram previamente descritas por Andrade et al. (1994) e Narciso Sobrinho et al. (1998a). Segundo Gerdes et al. (2000b) com o alongamento das hastes das gramíneas, especialmente no verão, como observado na Tabela 7, a participação do constituinte parede celular torna-se mais significativa e, conseqüentemente, a concentração de PB é menor, como mostra a Tabela 11. Esse fato foi também constatado por El-Memari Neto et al. (2002) que verificaram maiores teores de FDN e menores de PB nas hastes de capimMarandu quando comparadas às folhas. Ainda, de acordo com Omaliko (1980) a maior idade ao corte em gramíneas tropicais causa aumento na proporção de hastes, e conseqüente aumento de tecido estrutural da matéria seca.

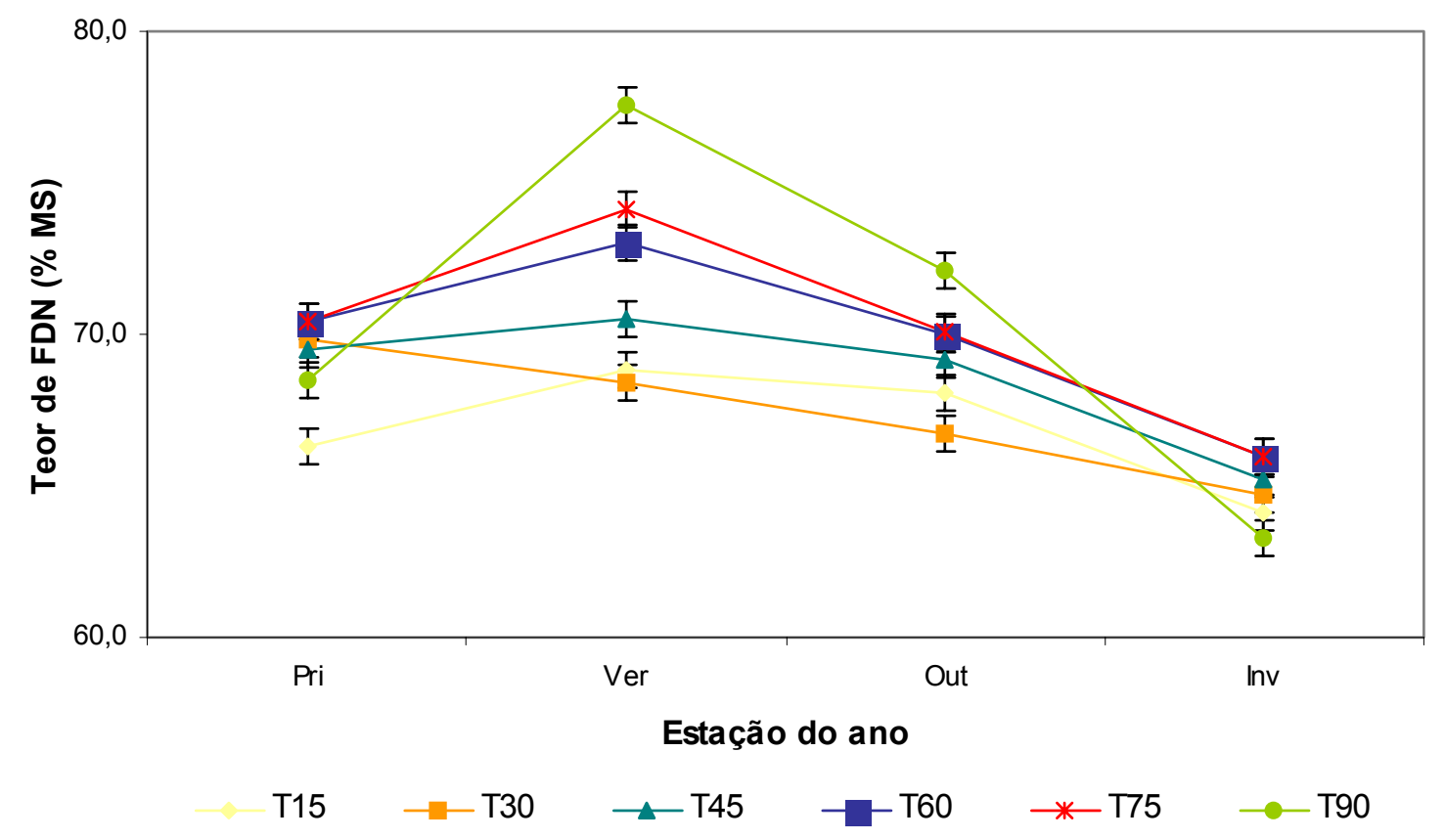

Figura 5 - Variação estacional dos teores de fibra insolúvel em detergente neutro nos diferentes intervalos entre cortes em capim-Marandu 
$\mathrm{Na}$ análise integrada das Tabelas 7 e 11 notou-se que apesar do aumento na participação das hastes na massa de MS de forragem ter ocorrido em todos intervalos, nas médias por tratamento, o teor de FDN não se alterou a partir dos 60 dias de intervalo entre cortes. Com isso, permite-se inferir que dos 60 até os 90 dias a perda em digestibilidade constatada (Tabela 13) não se deveu às alterações nos teores de FDN e de PB, sendo possivelmente atribuída à perda de digestibilidade específica de alguns nutrientes.

De acordo com Buxton \& Fales (1994), as reações que dão origem à síntese dos constituintes de parede celular são mediadas por enzimas e a temperatura influencia diretamente na concentração dessas. A temperatura determina a energia cinética das moléculas, a qual, por sua vez, é condicionante da ocorrência das reações. No presente estudo foram observados decréscimos nos teores de FDN ao longo das estações do ano (Tabela 11) na seguinte seqüência: verão, outono, primavera e inverno. Variações estacionais nos teores de FDN também foram encontrados por Gerdes et al. (2000b), embora a ordem de decréscimo tenha sido alterada. Apenas o corte de outono, conforme relatado pelos autores, diferiu dos resultados encontrados neste estudo, nas demais estações foram encontrados valores similares.

\subsubsection{Digestibilidade verdadeira in vitro da matéria seca da forragem}

Os resultados referentes à DVIVMS média da forragem estão apresentados na Tabela 13 e Figuras 6 e 7 . Houve efeito do intervalo entre cortes $(P<0,01)$, da estação do ano $(P<0,01)$ e da interação intervalo entre cortes $x$ estação do ano $(P<0,01)$, não tendo sido verificado efeito de bloco $(\mathrm{P}=0,14)$. Os valores encontrados de DVIVMS variaram de $54,7 \%$ (T90 de verão) a 70,0\% (T15 de primavera). Foram observados decréscimos nos coeficientes de DVIVMS conforme a forragem foi colhida em estádios fisiológicos mais avançados. Com relação às estações do ano a DVIVMS 
revelou menores coeficientes no verão e outono $(63,8 \%)$, aumentando na primavera para $65,1 \%$ e chegando ao máximo de $66,6 \%$ no inverno.

No desdobramento entre os tratamentos à que foi submetido o capimMarandu dentro das estações, observou-se que no verão e outono houve tendência de declínio na DVIVMS à medida que o intervalo entre cortes foi distanciado.

Tabela 13. Digestibilidade verdadeira in vitro da matéria seca (\%) do capimMarandu submetido a intervalos entre cortes durante as estações do ano

\begin{tabular}{lllllll}
\hline \multirow{2}{*}{ Tratamento } & \multicolumn{3}{c}{ Estação do ano } & \multirow{2}{*}{ Média } & \multirow{2}{*}{ EPM* } \\
& Primavera & Verão & Outono & Inverno & & \\
\hline T15 & $70,0^{\mathrm{aA}}$ & $67,4^{\mathrm{aA}}$ & $64,7^{\mathrm{bB}}$ & $67,6^{\mathrm{aA}}$ & $67,4^{\mathrm{a}}$ & 0,47 \\
T30 & $62,5^{\mathrm{bcB}}$ & $69,7^{\mathrm{aA}}$ & $67,8^{\mathrm{aA}}$ & $67,6^{\mathrm{aA}}$ & $66,9^{\mathrm{a}}$ & 0,47 \\
T45 & $64,7^{\mathrm{bA}}$ & $66,3^{\mathrm{bA}}$ & $64,6^{\mathrm{bA}}$ & $66,0^{\mathrm{abA}}$ & $65,4^{\mathrm{b}}$ & 0,47 \\
T60 & $61,7^{\mathrm{cA}}$ & $63,7^{\mathrm{bA}}$ & $62,9^{\mathrm{bA}}$ & $64,0^{\mathrm{bA}}$ & $63,1^{\mathrm{cd}}$ & 0,47 \\
T75 & $63,5^{\mathrm{bcB}}$ & $61,0^{\mathrm{cB}}$ & $63,2^{\mathrm{bB}}$ & $68,0^{\mathrm{aA}}$ & $63,9^{\mathrm{c}}$ & 0,47 \\
T90 & $68,1^{\mathrm{aA}}$ & $54,7^{\mathrm{dC}}$ & $59,9^{\mathrm{cB}}$ & $66,5^{\mathrm{abA}}$ & $62,3^{\mathrm{d}}$ & 0,47 \\
Média & $65,1^{\mathrm{B}}$ & $63,8^{\mathrm{C}}$ & $63,8^{\mathrm{C}}$ & $66,6^{\mathrm{A}}$ & & \\
EPM $^{*}$ & 0,38 & 0,38 & 0,38 & 0,38 & & \\
\hline
\end{tabular}

${ }^{*}$ EPM - erro padrão da média.

Médias na linha seguidas de mesmas letras maiúsculas não diferem entre si $(P>0,05)$.

Médias na coluna seguidas de mesmas letras minúsculas não diferem entre si $(P>0,05)$.

Estudos que têm relacionado digestibilidade com a idade de crescimento das plantas forrageiras têm demonstrado, geralmente, uma relação linear negativa entre essas variáveis (Gomide et al., 1969). Brito et al. (2001) encontraram para a digestibilidade da MS correlação negativa com o teor de FDN $(r=-0,88)$ e positiva com o teor de PB $(r=0,89)$. Como esperado, os resultados do presente estudo, ratificam as tendências entre o valor de DVIVMS e os teores de FDN e PB, de maneira antagônica. 
O aumento no intervalo entre cortes levando a declínio na DVIVMS havia sido observado por Acunha \& Coelho (1997); Gomide et al. (1985); Ribeiro et al. (1999); Ruggieri et al. (1995); Vilela et al. (1998) e Vilela et al. (2001). Esses autores encontraram coeficientes de DVIVMS similares aos obtidos neste trabalho.

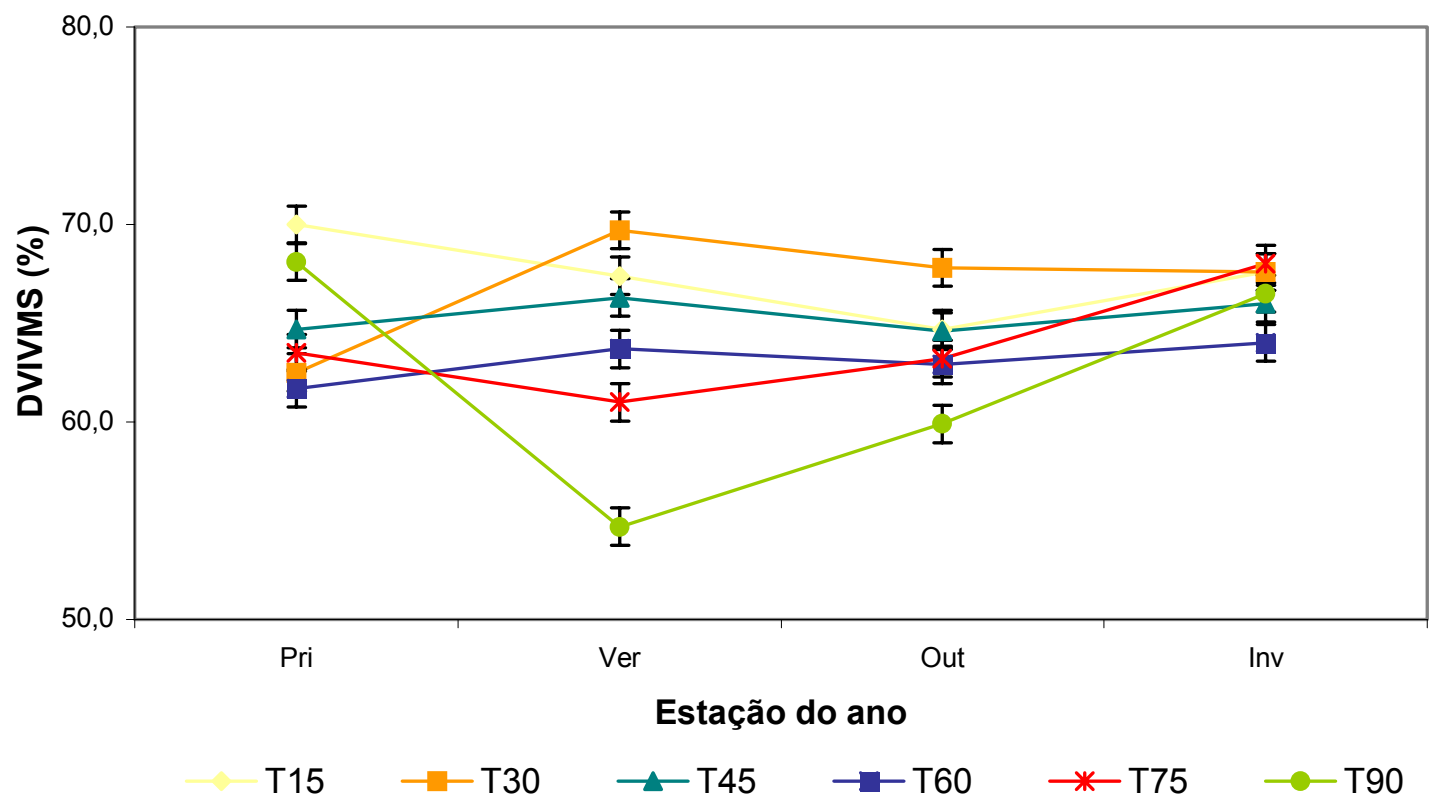

Figura 6 - Variação estacional dos coeficientes de digestibilidade verdadeira in vitro da matéria seca nos diferentes intervalos entre cortes em capim-Marandu

Assim como nos outros constituintes previamente discutidos a variação ocorrida na DVIVMS entre as estações reflete, principalmente, as variações ambientais e suas conseqüências. Ao contrário do que foi encontrado por Gerdes et al. (2000b) os menores valores de DVIVMS foram obtidos em forragens colhidas no verão e outono. Contudo, a variação entre estações no presente ensaio foi mais tênue que a observada pelos autores mencionados, 
mostrando, assim, uma menor variação da DVIVMS ao longo do ano quando comparadas.

\subsubsection{Produção de matéria seca digestível}

Os resultados referentes à produção total de matéria seca digestível do capim-Marandu estão apresentados na Tabela 14 e Figura 7. Houve efeito do intervalo entre cortes $(P<0,01)$ e de bloco $(P<0,01)$. A produção de matéria seca digestível no período experimental variou de $18,5 \mathrm{t}^{\text {ha }}{ }^{-1}$ (T15) até $13,2 \mathrm{t} \mathrm{ha}^{-1}$ (T45).

Tabela 14. Produção acumulada de matéria seca digestível do capim-Marandu submetido a intervalos entre cortes, durante 352 dias de período experimental

\begin{tabular}{|c|c|c|}
\hline Tratamento & $\begin{array}{l}\text { Produção de MS digestível } \\
\qquad \mathrm{t} \mathrm{ha}^{-1}\end{array}$ & $\mathrm{EPM}^{*}$ \\
\hline T15 & $18,5^{a}$ & 0,56 \\
\hline T30 & $14,6^{\mathrm{cd}}$ & 0,56 \\
\hline T45 & $13,2^{d}$ & 0,56 \\
\hline T60 & $17,1^{\mathrm{ab}}$ & 0,56 \\
\hline T75 & $18,0^{a}$ & 0,56 \\
\hline T90 & $16,0^{b c}$ & 0,56 \\
\hline Média & 16,2 & \\
\hline
\end{tabular}

${ }^{*} \mathrm{EPM}$ - erro padrão da média.

Médias na coluna seguidas de mesmas letras minúsculas não diferem entre si $(P>0,05)$.

A Figura 7 também mostra a produção de MS digestível (barras hachuradas) no período, que foi obtida através do produto entre as médias de produção de MS e da DVIVMS. Através da análise desta figura depreende-se que a maximização da produção de massa seca ocorreu tanto em forragens 
colhidas freqüentemente (T15) como naquelas manejadas sob intervalo entre cortes mais prolongados (T60, T75 e T90), havendo diminuição de produção de MS caracterizada nos intervalos intermediários (T30 e T45). Essa tendência se deu em função da direta dependência da produção acumulada de matéria seca que, no T30 e T45, apresentou comportamento semelhante e como foi anteriormente justificado na seção 3.3.1. Entretanto, o intervalo no qual a forragem apresentou maior valor nutritivo esteve situado entre 15 e 30 dias de intervalo entre cortes (Tabela 13 e Figuras 6 e 7 ).

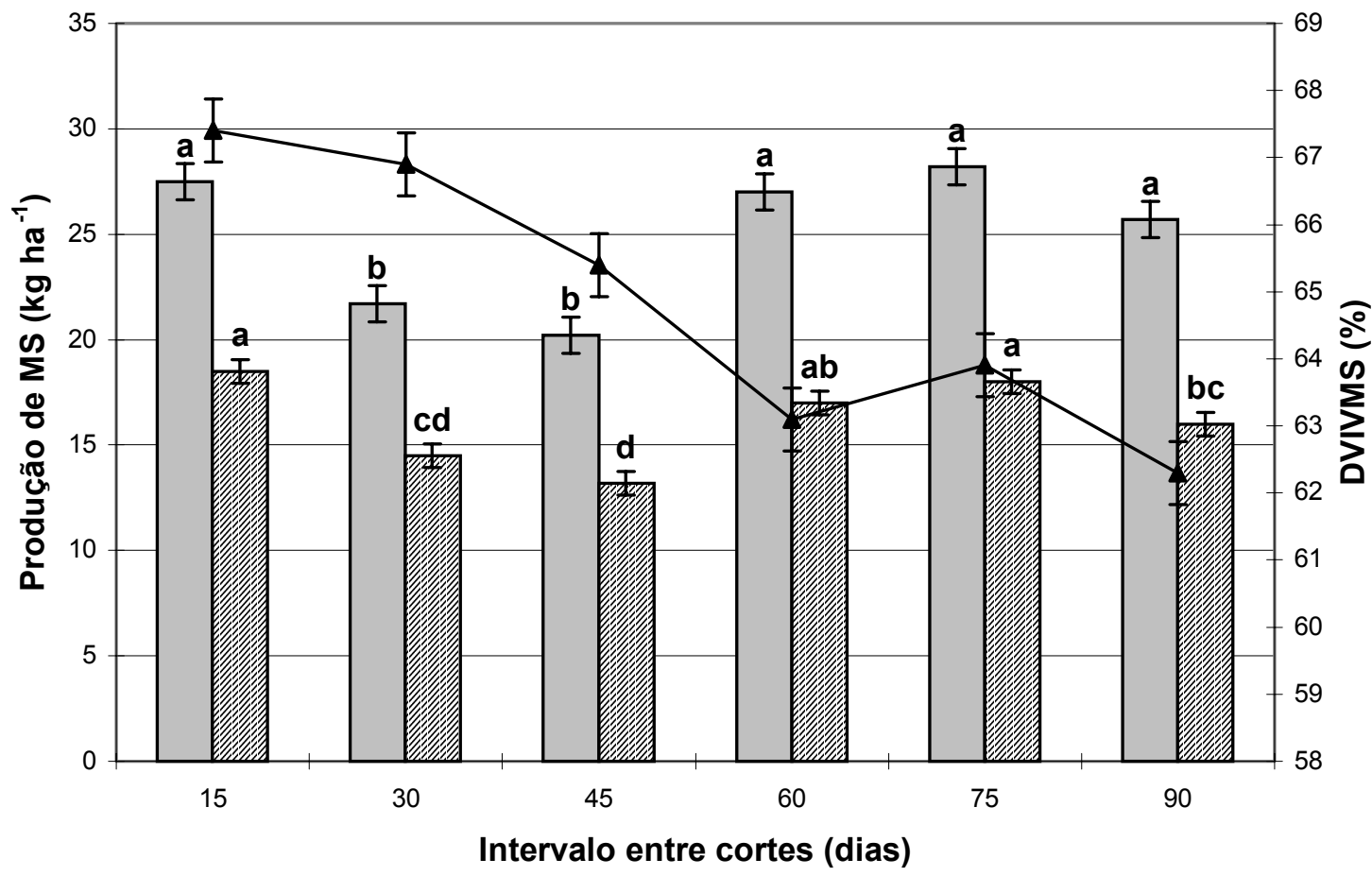

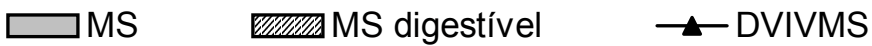

Figura 7 - Produção acumulada de matéria seca, matéria seca digestível e coeficiente de digestibilidade verdadeira in vitro da matéria seca observadas para os intervalos entre cortes em capim-Marandu 
O ponto ótimo, de máxima produção de massa seca digestível, foi alcançado nos tratamentos T15, T60 e T75, ou seja, ao redor de 15 dias de intervalo entre cortes ou entre 60 e 75 dias. Porém, como já justificada, a elevada produção de MS no T15 pode ser devida ao método de amostragem utilizada que, associada à elevada DVIVMS, característica das forragens jovens, pode ter resultado na superestimativa da produção de MS digestível. Além disso, deve-se reconhecer que o T15 envolve a necessidade de amparos logístico e operacional intensos para sua contemplação que seriam limitantes para a adoção em propriedades agrícolas tradicionais. Outro aspecto a ser considerado é que com essa freqüência de colheita os custos associados ao manejo do conjunto mecanizado seriam restritivos à adoção dessa estratégia de manejo. Também seriam necessários estudos de longa duração para verificar a possibilidade de manutenção do "stand" de plantas, nessas glebas onde são colhidas freqüentemente, uma vez que o esgotamento de reservas orgânicas vegetais pode ocorrer.

Com isso, permite-se inferir que o melhor intervalo entre cortes visando conciliar elevada produção de MS, de bom valor nutritivo, esteve ao redor dos 60 dias de crescimento vegetativo, quando a menor digestibilidade foi compensada pela maior produção de MS. Relatos de Gomide et al. (1985), mostraram que para o capim-Colonião menores intervalos entre cortes provocaram aumento na produção de MS digestível nos dois anos estudados, entretanto, para o capim-Jaraguá (Hyparrhenia rufa (Ness) Stapf), os mesmos autores, relataram um comportamento antagônico de um ano para o outro, sendo que no primeiro ano com a extensão do intervalo entre cortes o rendimento forrageiro decresceu. 


\subsection{Conclusões}

O prolongamento no intervalo entre cortes determinou acréscimos nos constituintes da parede celular e declínios nos componentes potencialmente solúveis, levando a decréscimos no valor nutritivo da forragem.

As variações ambientais ocorridas nas estações do ano levaram a alterações na composição morfológica das forragens e estas foram, por sua vez, responsáveis pelas alterações na composição químico-bromatológica.

A otimização da produção de MS digestível, que reflete a ponderação entre a variação na produção de MS e no valor nutritivo, ocorreu com forragens colhidas aos 60 dias de crescimento vegetativo, quando o declínio em digestibilidade foi compensado pela maior produção de matéria seca.

Há necessidade de se estudar a produção de capim-Marandu, manejado intensivamente para a produção de silagens, por um período mais prolongado para que se possa caracterizar aspectos relacionados com a persistência e equilíbrio da comunidade de plantas. 


\section{VALOR NUTRITIVO, ASPECTOS FíSICOS E PERDAS ASSOCIADAS À FERMENTAÇÃO DE SILAGENS DE CAPIM-MARANDU, CONFECCIONADAS COM FORRAGEM SUBMETIDA A INTERVALOS ENTRE CORTES}

\section{Resumo}

O presente trabalho teve como objetivos estudar o efeito do intervalo entre cortes e da estação do ano, sobre o valor nutritivo, aspectos físicos e perdas associadas ao processo fermentativo de silagens de capim-Marandu (Brachiaria brizantha (Hochst. ex A. Rich.) Stapf cv. Marandu). O delineamento experimental utilizado foi em blocos completos casualizados com cinco tratamentos (intervalos entre cortes) e quatro blocos, resultando em 20 parcelas com $100 \mathrm{~m}^{2}$ cada. Os tratamentos utilizados foram T15, T30, T45, T60 e T90, com silagens confeccionadas com forragens colhidas, respectivamente, aos 15 , $30,45,60$ e 90 dias de crescimento vegetativo. As silagens foram preparadas em duas estações do ano, verão e inverno, em baldes plásticos com capacidade de $20 \mathrm{~L}$, providos com tampa e uma válvula do tipo Bunsen para o escape dos gases produzidos pelo processo fermentativo, além de dispositivo para a quantificação do efluente. Após 90 dias de estocagem os silos foram abertos e foi analisada a composição químico-bromatológica das silagens e análises físicas (condutividade elétrica-CE, atividade de água-Aw, tamanho de partícula, densidade da massa verde de forragem-DMV e da massa secaDMS, produção de efluentes, perdas por gases e taxa de recuperação de MS). No verão, as silagens mostraram tendência de aumento $(P<0,05)$ nos 
constituintes da parede celular, exceto para hemicelulose $(P>0,05)$ e, conseqüente, redução nos componentes do conteúdo celular, conforme foi aumentado o intervalo entre cortes. Praticamente não houve alteração nos constituintes químicos das silagens confeccionadas no inverno. As digestibilidades verdadeiras in vitro da matéria orgânica (DVIVMO) médias das silagens de verão $(57,9 \%)$ foram menores que das silagens de inverno $(60,8 \%)$, principalmente devido aos elevados teores das frações da fibra. Não foram encontradas diferenças entre as estações do ano para os teores de cinzas (11\% MS), PB (10\% MS), hemicelulose (29,9\% MS), lignina (4\% MS) e pH $(4,9)$. O teor de MS médio das silagens de inverno $(39,0 \%)$ foi maior que nas silagens de verão (19,4\%). As medidas físicas demonstraram que tanto no verão quanto no inverno a CE foi maior nos intervalos de 15 e 30 dias, tornando-se menores $(P<0,01)$ com o prolongamento do intervalo entre cortes. Não houve diferença no tamanho médio das partículas das silagens de verão até os 45 dias de crescimento vegetativo, entretanto ocorreu aumento $(P<0,01)$ dos 60 aos 90 dias. Embora o tamanho médio das partículas de inverno $(34 \mathrm{~mm})$ não tenha sido diferente $(P>0,05)$ da encontrada no verão $(33 \mathrm{~mm})$, a produção de efluente no inverno foi de apenas $0,2 \mathrm{~kg} \mathrm{t}^{-1}$ de massa verde, enquanto a produção de efluente no verão foi, em média, $37,6 \mathrm{~kg} \mathrm{t}^{-1}$ de massa verde. $\mathrm{O}$ alto teor de MS nas silagens de inverno também levou a aumentos nas perdas por gases $(7,2 \%$ MS vs $4,7 \%$ MS). Houve tendência de maiores taxas de recuperação de MS nas silagens de inverno $(97,2 \% \mathrm{MS})$ e naquelas de verão confeccionadas com forragem de intervalo entre cortes foi mais prolongado (T60 e T90), o que também pode ser relacionado ao maior teor de MS dessas silagens. 


\section{NUTRITIVE VALUE, PHYSICAL TRAITS AND FERMENTATION LOSSES OF MARANDU GRASS SILAGE SUBMITTED TO CUTTING INTERVALS}

\section{Summary}

The objectives of this trial were to evaluate cutting intervals and season of the year on nutritive value, physical traits and losses associated to the fermentative process of Marandu grass (Brachiaria brizantha (Hochst. ex A. Rich.) Stapf cv. Marandu) silage. The trial was placed in 20 field plots $(10 \mathrm{~m} \times$ $10 \mathrm{~m}$ ), assigned to 5 cutting intervals (treatments), 4 replications each, in a randomized block design. Treatments consisted of Marandu grass harvested at $15,30,45,60$ and 90-d intervals. The chopped forage was ensiled, both in the summer (January) and in the winter (July) cuts, in 20L plastic buckets provided with a Bunsen type valve to allow gases to escape and an absorbent device to drain the effluent. After $90-d$ storage period, silage samples were submitted to chemical and physical analysis (electrical conductivity-EC, water activity-Aw, particle size-PS, fresh matter density-FMD, dry matter density-DMD, effluent-E yield, gases losses and dry matter recovery rate-DMRR). The summer cut silages showed a trend $(P<0.05)$ for increased cell wall fractions, except hemicellulose $(P>0.05)$ and decreased cell soluble contents as the cutting intervals were increased. However, there were no differences on chemical composition among treatments for the winter cut silages. Mean digestibilities in summer cut $(58.18 \%)$ were lower than the winter cut silages $(60.24 \%)$ mainly due to the higher fiber fractions. No differences were observed for $\mathrm{pH}(4.9)$, ash (11\%), CP (10\%), hemicellulose (29.9\%) and lignin (4.0\%) across seasons. The

DM content in the winter cut $(39.0 \%)$ was higher than the summer cut silages (19.4\%). The EC was increased at 15-d and 30-d cutting intervals and decreased $(P<0.01)$ in later cuts. The PS did not alter up to $45-d$ cutting intervals, although, it was increased $(P<0.01)$ from 60 -d to $90-d$ cuts. Even tough, there was no difference in PS between seasonal cuts $(P>0.05)$ effluent 
yield was only $0.16 \mathrm{~L} \mathrm{t}^{-1}$ in the winter when compared to $37.6 \mathrm{~L} \mathrm{t}^{-1}$ observed in summer silages. The higher DM content observed in the winter cut silages also led to increased losses associated with gases yield (7.24\% DM vs $4.69 \% \mathrm{DM})$. Enhanced DMRR might be achieved, both, in the winter and from 60-d to 90-d cut intervals in the summer silages, which also is related with higher silage DM content.

\subsection{Introdução}

Ocorre no Brasil, assim como nos outros países do trópico Sul, uma marcante estacionalidade da produção de forragens, sendo esse o principal fator de restrição na exploração da produção pecuária nacional. Ocorrem, durante o ano, períodos cíclicos de alta e baixa produção de forragem, característica das gramíneas de clima tropical, que conflita com o benefício do alto potencial de produção de matéria seca por área.

Durante a época chuvosa (outubro a março), devido à alta disponibilidade de forragem e seu bom valor nutritivo, observa-se desempenho animal satisfatório. No entanto, na época de estiagem (abril a setembro), ocorre acentuada redução na produção das pastagens, determinando perda de peso dos animais e/ou drástica redução na produção de leite.

Para amenizar esse problema busca-se o manejo integrado da pastagem, que visa conservar o excedente de forragem da estação de produção a fim desse ser utilizado no período da seca. Os processos de fenação e/ou ensilagem são práticas convencionalmente utilizadas de conservação de forragem, sendo a produtividade e o valor nutritivo da forragem aspectos importantes a serem considerados quando da utilização dessas práticas de conservação em vista dos custos operacionais dos processos.

Visando oferecer alternativas às culturas anuais convencionais (milho e sorgo) e, sobretudo, associado ao manejo do pastejo, em 1935 foram iniciados 
trabalhos com a ensilagem de gramíneas tropicais, que, entretanto, somente foram intensificados na década de 70 , em especial com o capim-elefante. Após esse primeiro momento de interesse da utilização de silagens de gramíneas tropicais, houve certa diminuição na evolução dessa técnica devido, provavelmente, à falta de equipamentos apropriados para o processo de conservação dessas forragens na forma de silagem. Na última década as empresas nacionais passaram a desenvolver e produzir os equipamentos capazes de picar a forragem colhida de forma mais eficiente, gerando novo estímulo a essa prática.

Dentre as espécies forrageiras existentes, as do gênero Brachiaria apresentam destacada participação no mercado brasileiro, adaptando-se às variadas condições de clima e solo. Porém sua extensa utilização deve-se, principalmente, à sua adaptação às condições de solos com baixa e média fertilidade. Apesar da destacada representação da braquiária decumbens dentre as espécies do gênero, essas gramíneas vêm apresentando declínio da produção após ciclos de pastejo. A partir da década de 80 , foi introduzido pela EMBRAPA o capim-Marandu, passando a ser largamente utilizado em pastejo e, mais recentemente, tem sido despertado o interesse no seu uso para os processos de conservação.

O presente trabalho teve como objetivo estudar o efeito do intervalo entre cortes e da estação do ano, sobre o valor nutritivo, aspectos físicos e perdas associadas ao processo fermentativo de silagens de capim-Marandu, visando estabelecer estratégias para aumentar a eficiência técnica e econômica dessa exploração. 


\subsection{Material e Métodos}

\subsubsection{Material}

\subsubsection{Espécie vegetal}

Foi utilizado o capim-Marandu que, de acordo com Cronquist (1988) classifica-se como pertencente à divisão Magnoliophyta; à classe Liliopsida; à subclasse Commelinidae; à ordem Cyperales; à família Poaceae; à subfamília Panicoideae; à tribo Panicodae; à subtribo Paniceae; ao gênero Urochloa; à espécie Urochloa brizantha (Hochst. ex A. Rich.) Webster; à variedade Urochloa brizantha (Hochst. ex A. Rich.) Webster var Marandu.

\subsubsection{Local e data do experimento}

O experimento foi conduzido em área localizada com as coordenadas geográficas aproximadas de $22^{\circ} 42^{\prime}$ de latitude sul, $47^{\circ} 38^{\prime}$ de longitude oeste e altitude de $546 \mathrm{~m}$, pertencente ao Departamento de Aviação Civil (DAC) do Estado de São Paulo e utilizada sob concessão ao Departamento de Produção Animal - Setor Ruminantes, USP/ESALQ, em Piracicaba, SP. As ensilagens ocorreram em 31 de janeiro de 2002 (verão) e 18 de julho de 2002 (inverno).

\subsubsection{Solo da área experimental}

ARGISSOLO VERMELHO-AMARELO Eutrófico típico (EMBRAPA, 1999) e cuja composição química média é apresentada na Tabela 1 (seção 3.2.1.3). 


\subsubsection{Clima}

Os dados climáticos referentes ao período experimental foram coletados no posto meteorológico do Departamento de Ciências Exatas da USP/ESALQ, localizado aproximadamente a $1000 \mathrm{~m}$ da área experimental como apresentados na Tabela 2 (seção 3.2.1.5).

\subsubsection{Forragem utilizada para preparação das silagens}

A forragem utilizada para enchimento dos silos experimentais (unidades experimentais) teve sua composição químico-bromatológica predita pelo sistema NIRS e corresponde aos cortes referentes às datas das ensilagens, uma vez que as parcelas foram mantidas em regime de cortes sistemáticos conforme descrito no capítulo 3 (seção 3.2.2.5.2). As médias da composição químico-bromatológica da massa de forragem estão apresentadas nas Tabelas 15 e 16. 
Tabela 15. Teores de matéria seca, cinzas, extrato etéreo, fibra insolúvel em detergente neutro, fibra insolúvel em detergente ácido, hemicelulose, celulose e lignina da massa de forragem de capimMarandu colhida para ensilagem nos intervalos entre cortes, nas duas estações

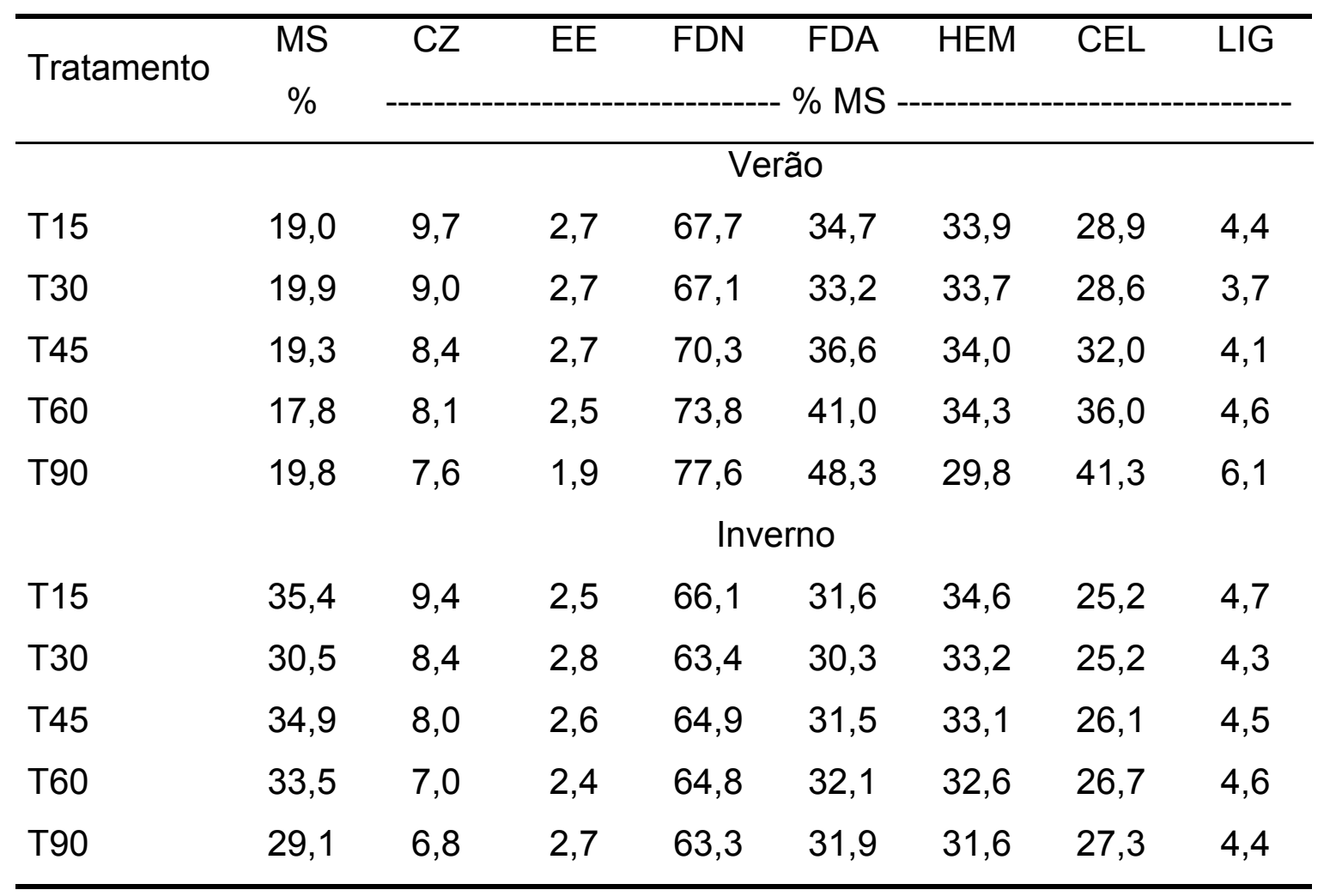


Tabela 16. Teores de proteína bruta, nitrogênio ligado à fibra insolúvel ao detergente ácido, nitrogênio ligado à fibra insolúvel ao detergente neutro, fração B3, digestibilidade verdadeira in vitro da matéria seca e digestibilidade verdadeira in vitro da matéria orgânica da massa de forragem de capim-Marandu colhida para ensilagem nos intervalos entre cortes, nas duas estações

\begin{tabular}{lcccccc}
\hline Tratamento & PB & NFDA & NFDN & B3 $^{*}$ & DVIVMS & DVIVMO \\
& \% MS & - --------- $\%$ & N total ${ }^{-1}$ & & & \\
& & \multicolumn{5}{c}{ Verão } \\
T15 & 14,4 & 4,5 & 24,0 & 19,5 & 66,7 & 63,9 \\
T30 & 12,8 & 4,8 & 33,4 & 28,6 & 70,4 & 67,7 \\
T45 & 12,0 & 5,7 & 36,5 & 30,8 & 67,6 & 64,8 \\
T60 & 9,1 & 7,7 & 38,7 & 31,0 & 63,0 & 59,3 \\
T90 & 6,7 & 9,9 & 35,5 & 25,6 & 54,7 & 52,1 \\
& & & & Inverno & & \\
T15 & 9,9 & 10,5 & ND** & ND & 62,7 & 60,6 \\
T30 & 10,7 & 9,2 & ND & ND & 67,4 & 65,3 \\
T45 & 8,9 & 11,2 & ND & ND & 63,4 & 62,6 \\
T60 & 7,8 & 11,5 & ND & ND & 64,3 & 63,5 \\
T90 & 8,7 & 10,5 & ND & ND & 66,5 & 65,5 \\
\hline
\end{tabular}

${ }^{\text {*B} 3 ~-~ d i f e r e n c ̧ a ~ e n t r e ~ o s ~ n i ́ v e i s ~ d e ~ N F D N ~ e ~ N F D A . ~}$

${ }^{* \star} \mathrm{ND}$ - não determinado. 


\subsubsection{Silos experimentais}

Para a confecção dos silos experimentais (unidades experimentais), foram utilizados baldes plásticos com 20 litros de capacidade com tampas apropriadas para garantir a vedação adequada. No fundo do balde foram colocados $2 \mathrm{~kg}$ de areia seca, protegida com uma tela fina de plástico e uma camada de tecido de algodão, com a finalidade de evitar o contato da areia com a forragem e permitir a medida quantitativa do efluente produzido. Na tampa do balde (silo experimental), foi confeccionada uma válvula de escape do tipo Bunsen para escape dos gases produzidos, afim de que as perdas de matéria seca, devido ao processo fermentativo, fossem quantificadas gravimetricamente (Figura 8).

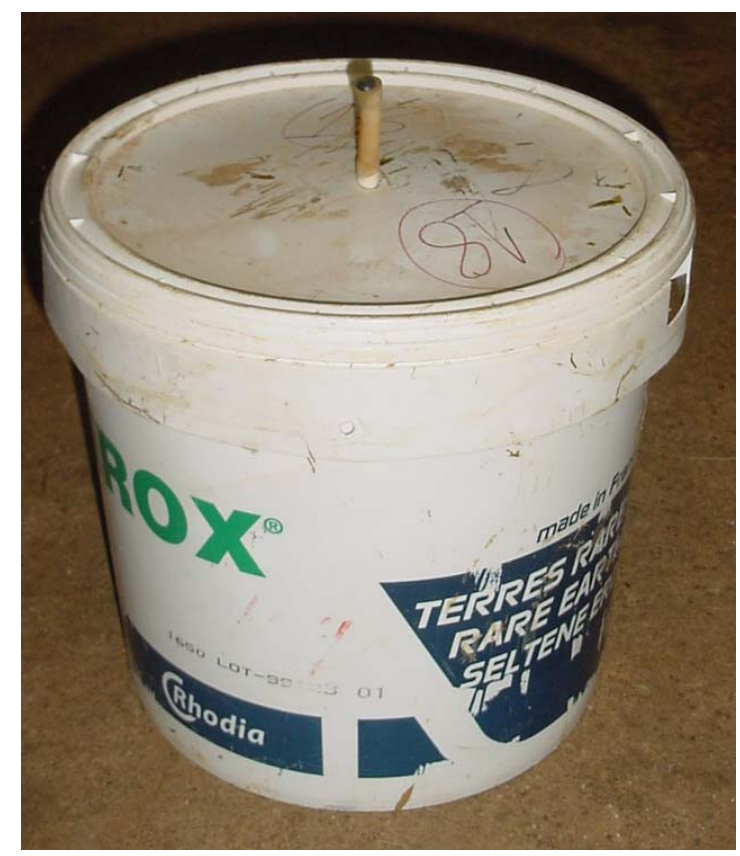

Figura 8 - Silo experimental com 20 L de capacidade, com válvula do tipo Bunsen adaptada para o escape de gases e dispositivo para drenagem de efluentes 


\subsubsection{Métodos}

\subsubsection{Delineamento experimental e tratamentos}

O experimento foi realizado seguindo o delineamento de blocos completos casualizados, com quatro repetições. Os tratamentos corresponderam a cinco intervalos entre cortes de 15, 30, 45, 60 e 90 dias, respectivamente, T15, T30, T45, T60 e T90. O intervalo entre cortes de 75 dias foi excluído desse ensaio em virtude da não possibilidade do sincronismo de seu corte no momento da confecção das silagens, tanto no inverno quanto o verão. O experimento apresentou um total de 20 parcelas (4 blocos $\times 5$ tratamentos). Foram planejados 20 silos experimentais (unidades experimentais) por estação do ano (verão e inverno). Entretanto, essa meta foi atingida somente nos cortes de verão, uma vez que durante o inverno, em virtude da menor produção de forragem das parcelas, não foi possível obter todos os silos experimentais (quatro repetições), havendo, com isso, a necessidade de agrupamento de amostras. Apenas no T90 foi possível ter todos os quatro silos experimentais completos, com necessidade de agrupamento de forragem para T30, T45 e T60, e no T15, mesmo compondo-se a forragem colhida nas quatro parcelas, não foi possível obter um silo experimental.

\subsubsection{Correção e adubação do solo}

No decorrer do ensaio de produção de matéria seca e sua composição químico-bromatológica (capítulo 3) foram realizadas correções nas propriedades químicas do solo e fornecimento de nutrientes a fim de proporcionar, à forragem, condições de expressar potencial produtivo e valor nutritivo adequados, compatíveis com a exploração proposta. Para tanto, foi efetuada aplicação de $630 \mathrm{~kg} \mathrm{ha}^{-1}$ de calcário dolomítico no dia 03/09/2001. Em 
14/11/2001 foram aplicadas doses equivalentes a $170 \mathrm{~kg} \mathrm{ha}^{-1}$ de $\mathrm{KCl}, 200 \mathrm{~kg}$ $\mathrm{ha}^{-1}$ de Superfosfato simples e $50 \mathrm{~kg} \mathrm{ha}^{-1}$ de micronutrientes (FTE BR-16 ${ }^{\circledR}$ ) em cada parcela. As adubações de cobertura realizadas com auxílio de adubadora pendular marca Vicon ${ }^{\circledR}$ tracionada por trator, ocorreram entre 14/11/2001 e 13/04/2002, a intervalos de 30 dias, com três aplicações da fórmula 30-00-20 na dosagem de $250 \mathrm{~kg} \mathrm{ha}^{-1}$, seguidas de três aplicações da fórmula 20-00-20, na dosagem de $375 \mathrm{~kg} \mathrm{ha}^{-1}$, totalizando $4,50 \mathrm{~kg}$ de $\mathrm{N}$ e $3,75 \mathrm{~kg}$ de $\mathrm{K}_{2} \mathrm{O}$ por parcela $\mathrm{ano}^{-1}$, equivalentes às doses de $450 \mathrm{~kg} \mathrm{~N} \mathrm{ha}^{-1} \mathrm{ano}^{-1}$ e $375 \mathrm{~kg} \mathrm{~K}_{2} \mathrm{O} \mathrm{ha}{ }^{-1} \mathrm{ano}^{-1}$, respectivamente.

\subsubsection{Colheita da forragem para enchimento dos silos experimentais}

A colheita foi realizada com a colhedora de forragem marca Casale ${ }^{\circledR}$, modelo CF 2000 Super, tracionada por trator, sendo cada parcela colhida separadamente (Figura 9).

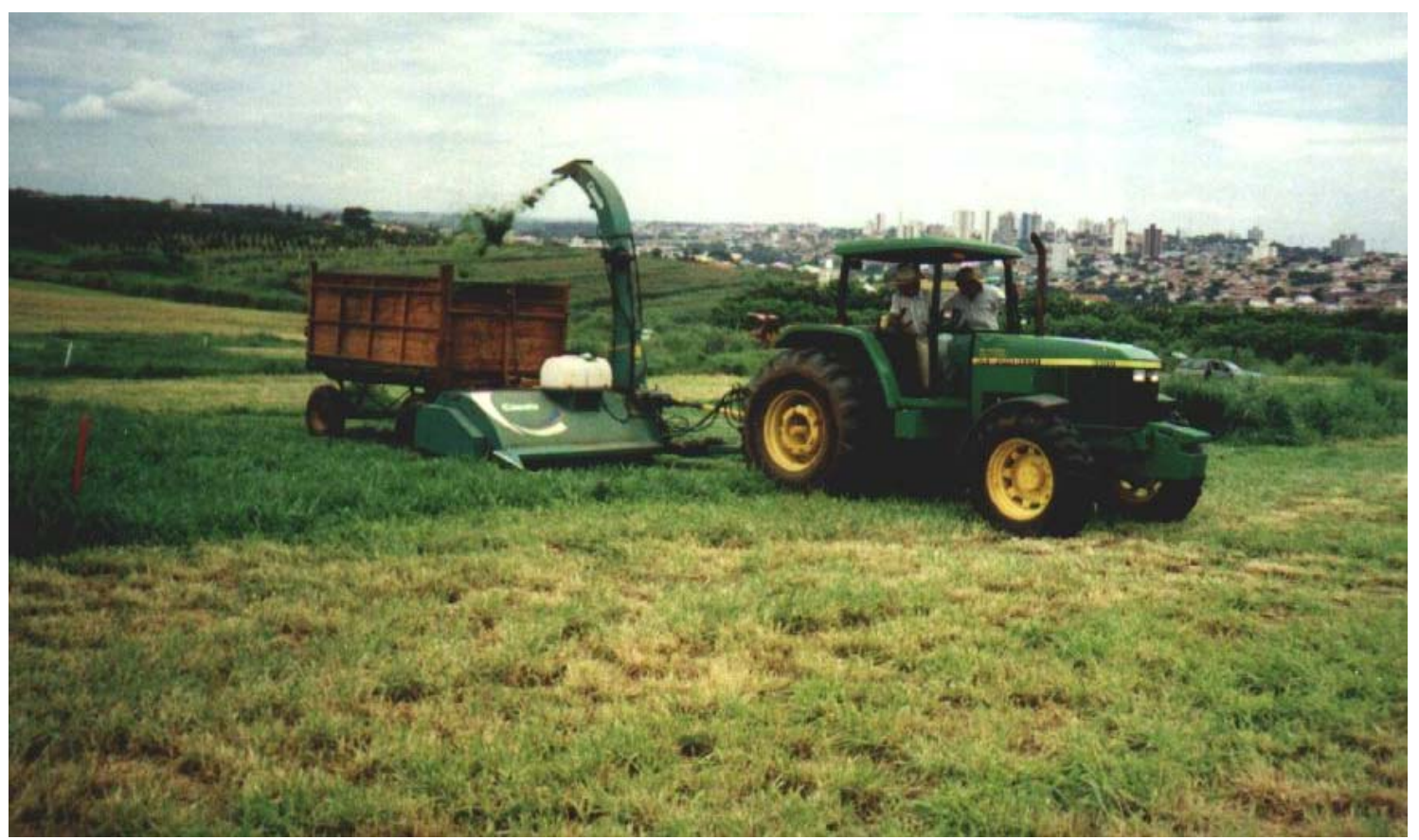

Figura 9 - Detalhe da parcela experimental sendo cortada e colhida 
Para o corte, a máquina teve seu conjunto de facas afiado e o conjunto de contra-facas foi aproximado para que se obtivesse o menor tamanho de partícula possível. Após o corte de toda a parcela, a forragem picada, contida no vagão forrageiro, foi depositada sobre uma lona plástica, homogeneizada e acondicionada nos silos experimentais.

\subsubsection{Enchimento dos silos experimentais}

A forragem foi compactada com os pés, tomando-se como critério a acomodação de camadas de aproximadamente $10 \mathrm{~cm}$ de espessura, de forma que a pressão exercida em cada balde fosse semelhante e tornasse possível a observação de diferenças na densidade dos diferentes tratamentos como resultado das características físicas do material ensilado.

Com a acomodação final da forragem, o silo experimental foi fechado e vedado na tentativa de se evitar a entrada de ar no balde. Em seguida, a massa dos baldes foi quantificada e esses foram armazenados em local protegido e mantidos sob temperatura ambiente.

\subsubsection{Abertura dos silos experimentais}

Decorridos 90 dias do fechamento, os silos experimentais foram abertos, seguindo o seguinte procedimento:

- Pesagem do balde antes da abertura;

- Amostragem da silagem;

- Pesagem da silagem;

- Pesagem da areia. 


\subsubsection{Determinação das perdas por gases}

As perdas por gases foram calculadas pela subtração do peso do balde cheio, computado na abertura dos silos, daquele observado no fechamento dos mesmos e expressas como a porcentagem da massa de forragem seca acondicionada nos silos e descrita pela Equação 4, abaixo:

$G=\left(\frac{\text { Pci }- \text { Pcf }}{M F i \times M S i}\right) \times 10000$

onde:

$\mathrm{G} \quad=$ perdas por gases $(\% \mathrm{MS})$;

Pci = peso do balde cheio no fechamento $(\mathrm{kg})$;

Pcf = peso do balde cheio na abertura $(\mathrm{kg})$;

$\mathrm{MFi}=$ massa de forragem no fechamento $(\mathrm{kg})$;

$\mathrm{MSi}$ = teor de matéria seca da forragem no fechamento (\%).

\subsubsection{Determinação da produção de efluentes}

Após retirar toda a silagem (Figura 10), a areia, disposta em camadas ao fundo, foi quantificada e de sua massa foi subtraída da massa original da areia observada antes do enchimento dos silos, permitindo a estimativa da produção de efluente, conforme descrito pela Equação 5:

$E=\frac{[(P v f-T b)-(P v i-T b)]}{M F i} \times 1000$

onde:

$\mathrm{E} \quad=$ produção de efluentes $\left(\mathrm{kg} \mathrm{t}^{-1}\right.$ massa verde);

Pvi = peso do balde vazio + peso da areia no fechamento $(\mathrm{kg})$; 
Pvf = peso do balde vazio + peso da areia na abertura $(\mathrm{kg})$;

$\mathrm{Tb}=$ tara do balde vazio $(\mathrm{kg})$;

$\mathrm{MFi}$ = massa de forragem no fechamento $(\mathrm{kg})$.

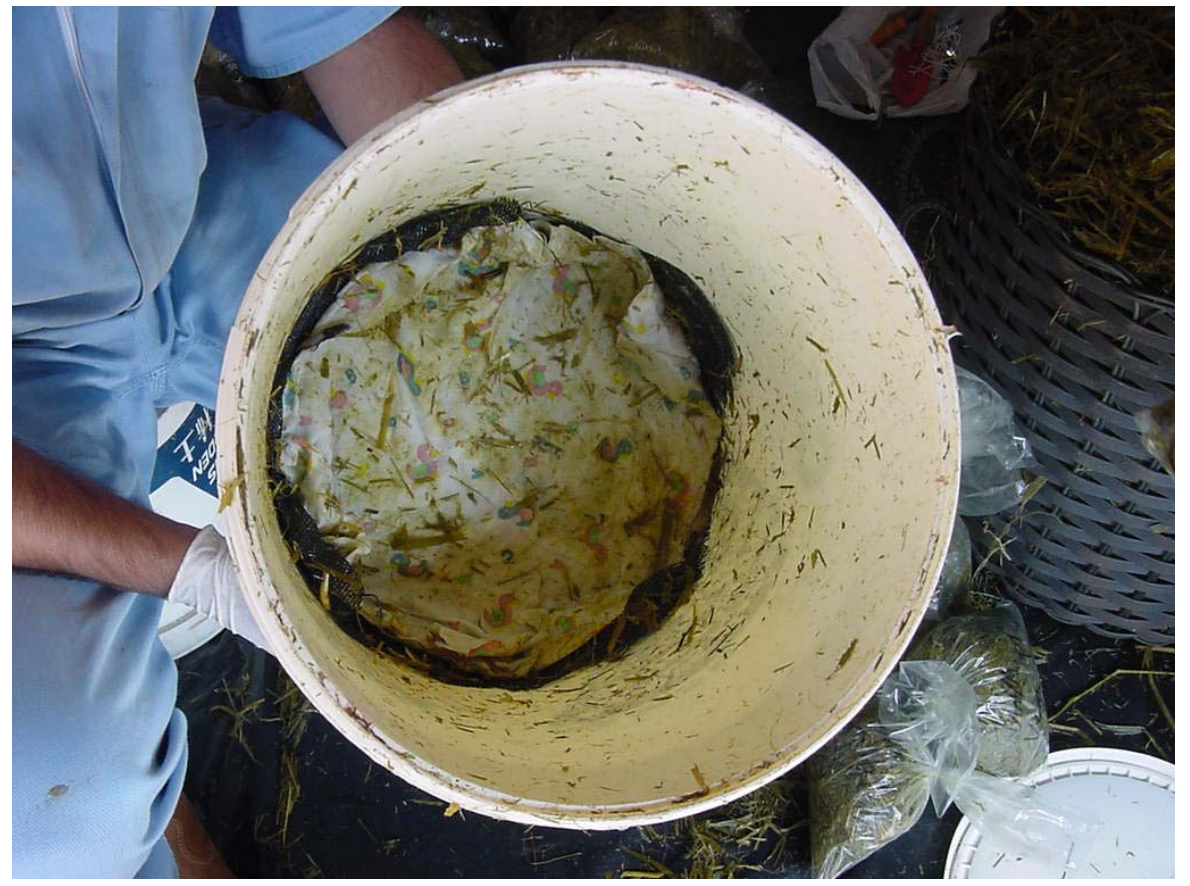

Figura 10 - Detalhe do balde após abertura para quantificação do efluente produzido durante o processo fermentativo

\subsubsection{Determinação da taxa de recuperação da matéria seca}

Foi obtida pelo quociente entre a quantidade de matéria seca recuperada dos baldes (abertura) e a quantidade de matéria seca inicialmente acondicionada nos baldes (fechamento) e expressa em porcentagem, conforme descrita pela Equação 6:

$\mathrm{RMS}=\left(\frac{\mathrm{MFf} \times \mathrm{MSf}}{\mathrm{MFi} \times \mathrm{MSi}}\right) \times 100$ 
onde:

RMS = taxa de recuperação de matéria seca (\%);

$\mathrm{MFi}$ = massa de forragem no fechamento $(\mathrm{kg})$;

$\mathrm{MSi}$ = teor de matéria seca da forragem no fechamento (\%);

MFf = massa de forragem na abertura $(\mathrm{kg})$;

MSf = teor de matéria seca da silagem na abertura (\%).

\subsubsection{Coleta de amostras}

\subsection{Amostragem e amostras}

Foram retiradas amostras para as análises de Aw, CE, tamanho de partículas, extrato aquoso, $\mathrm{pH}$, análise bromatológica (MS, cinzas, PB, FDN, FDA, hemicelulose, celulose, lignina), DVIVMO e DVIVMS. Para a tomada da amostra da silagem foi retirada uma alíquota originada da porção central do silo na tentativa de representar o centro geométrico desse volume, desprezando-se as áreas contaminadas por fungos, bolores e leveduras. As amostras destinadas às análises de Aw e CE foram resfriadas com a finalidade de que não ocorresse ruptura das células da forragem. Aquelas destinadas à análise granulométrica foram imediatamente processadas, enquanto que as destinadas à determinação do extrato aquoso e $\mathrm{pH}$, foram congeladas. As que foram encaminhadas à análise bromatológica foram secadas em estufa de circulação forçada de $\operatorname{ar}\left(55^{\circ} \mathrm{C}\right) \mathrm{e}$, posteriormente, prodeceu-se a moagem do material em moinho tipo Willey provido de peneira com orifícios de $1 \mathrm{~mm}$ de diâmetro. 


\subsection{Determinação da atividade de água das silagens}

As determinações de Aw foram realizadas através do uso do medidor de atividade de água, modelo Novasina ms 1 , marca Defensor ${ }^{\circledR}$. Para tanto iniciouse o procedimento com a calibração do equipamento, à temperatura ambiente, com o auxílio de uma célula de padronização inserida no sensor de leitura até sua estabilização. Em seguida, procedeu-se a leitura com a pesagem de $25 \mathrm{~g}$ de amostra fresca acondicionada dentro de um copo plástico com tampa e, através de um orifício na mesma, introduziu-se o sensor do aparelho e anotouse a leitura da amostra.

\subsection{Determinação da condutividade elétrica das silagens}

A determinação das perdas de conteúdo intracelular resultante dos tratamentos experimentais foi realizada através da mensuração da CE (Pauly, 1999). O método é baseado na mensuração indireta da quantidade de líquido intracelular liberado pela picagem da forragem e conseqüente ruptura de membrana celular, resultando na avaliação dos eletrólitos dispersos em solução, originados do fluído celular extravasado pelo rompimento de tecido vegetal. A medição foi realizada segundo proposta de Kraus et al. (1997), onde a forragem foi agitada com água deionizada, filtrada e a solução resultante foi submetida à leitura por um condutivímetro da marca Digimed ${ }^{\circledR}$, modelo CD 20.

\subsection{Determinação do tamanho de partícula das silagens}

A avaliação do tamanho de partículas foi realizada com base na estratificação dessas partículas através do método "Penn State Particle Size Separator" (Lammers, 1996). Entretanto, foi incorporada uma adaptação ao método original com a inserção de uma peneira adicional com orifícios de diâmetro de 38 mm (Figura 11). 


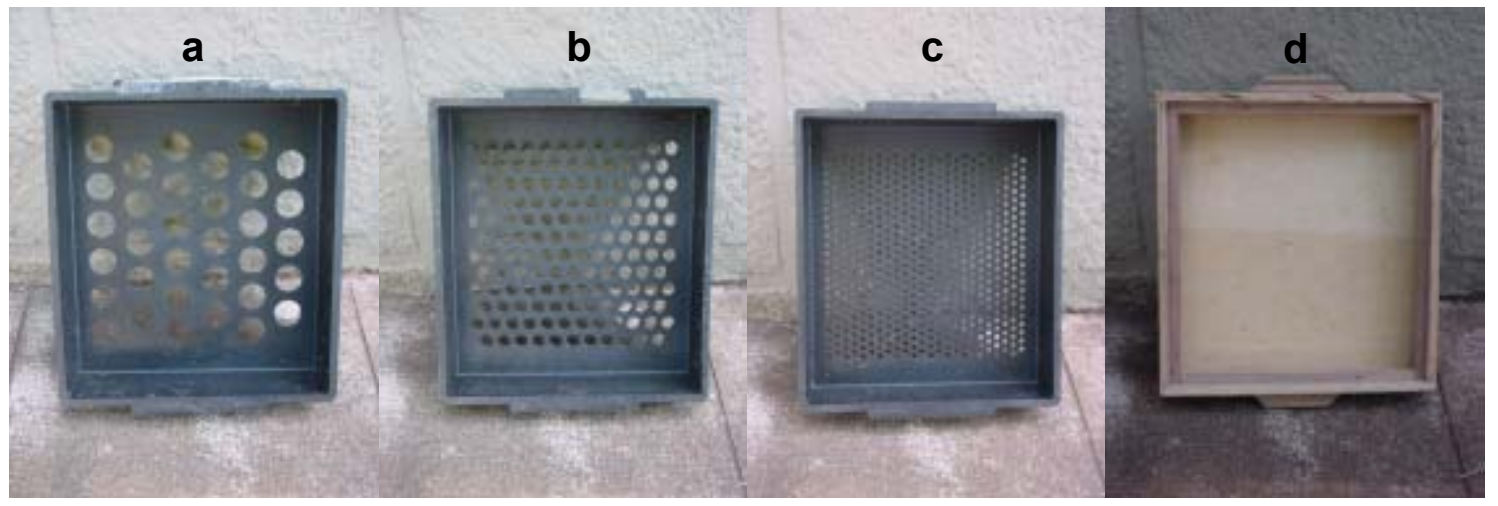

Figura 11 - Sistema Penn State Particle Size Separator com a adaptação da peneira superior (a) com perfurações de $38 \mathrm{~mm}$ e o sistema utilizado convencionalmente com as demais peneiras $(b, c, d)$

Com a adaptação foi definida a proporção de material retido com diâmetro superior a $38 \mathrm{~mm}$ (Figura 11a), material retido com diâmetro entre 38 e $19 \mathrm{~mm}$ (Figura 11b), material retido com diâmetro entre 19 e 7,8 mm (Figura 11c) e inferior a $7,8 \mathrm{~mm}$ (Figura 11d). Essa alteração se fez necessária ao analisar-se os dados de Igarasi (2002) e os resultados preliminares, gerados em pré-teste, do presente experimento como mostra a distribuição percentual da massa de forragem ensilada estratificada nas peneiras durante o verão (Tabela 17). O tamanho médio de partículas foi estimado através da ponderação da proporção de retenção de material em cada uma das peneiras do sistema Penn State Particle Size Separator. 
Tabela 17. Retenção percentual de partículas de capim-Marandu, durante o corte de verão, submetido a intervalo entre cortes, utilizando-se o método Penn State Particle Size Separator convencional e adaptado com quatro peneiras

\begin{tabular}{lccccccc}
\hline \multirow{2}{*}{ Tratamento } & \multicolumn{7}{c}{ \% Material retido } \\
& $\mathrm{P} 1^{*}$ & $\mathrm{P}^{*}$ & $\mathrm{P}^{*}$ & $\mathrm{PN} 1^{* *}$ & $\mathrm{PN2}^{* *}$ & $\mathrm{PN3}^{* *}$ & $\mathrm{PN}^{* *}$ \\
\hline T15 & 78,0 & 16,5 & 5,5 & 30,0 & 44,0 & 21,5 & 4,5 \\
T30 & 80,5 & 14,5 & 5,0 & 50,5 & 28,5 & 17,0 & 4,0 \\
T45 & 85,0 & 10,5 & 4,5 & 66,0 & 18,0 & 13,0 & 3,0 \\
T60 & 88,5 & 9,0 & 2,5 & 69,5 & 18,5 & 10,0 & 2,0 \\
T90 & 88,0 & 9,5 & 2,5 & 67,0 & 20,0 & 10,5 & 2,0 \\
\hline
\end{tabular}

${ }^{*} \mathrm{P} 1, \mathrm{P} 2, \mathrm{P} 3$ - Utilizando-se três peneiras.

${ }^{* *}$ PN1, PN2, PN3, PN4 - Utilizando-se quatro peneiras.

\subsection{Determinação do $\mathrm{pH}$ e do extrato aquoso das silagens}

Após descongelamento das amostras foi realizada a medição do pH com o uso de potenciômetro digital modelo DM 20, marca Digimed ${ }^{\circledR}$, seguindo método proposto por Kung Junior et al. (1984). Para tanto, utilizou-se $25 \mathrm{~g}$ de amostra e $225 \mathrm{~mL}$ de água deionizada, os quais foram processados em liquidificador industrial, modelo TA-02, da marca Skymsen ${ }^{\circledR}$, durante um minuto, dando origem ao extrato aquoso, que teve seu $\mathrm{pH}$ medido e foi, posteriormente, filtrado em papel de filtro Whatman ${ }^{\circledR} 54$. Após a filtragem, o extrato foi acidificado, centrifugado e congelado para posterior análise de ácido lático, ácidos graxos voláteis (AGV), carboidratos solúveis (CS) e nitrogênio amoniacal $\left(\mathrm{N}-\mathrm{NH}_{3}\right)$, seguindo o método proposto pelo autor supracitado (dados não apresentados). 


\subsection{Determinação do teor de matéria seca das silagens}

As amostras destinadas à análise bromatológica foram acondicionadas em sacos de papel, pesadas e mantidas em estufa de circulação forçada de ar $\left(55{ }^{\circ} \mathrm{C}\right)$ até peso constante, sendo determinado assim, o teor de MS da amostra.

\subsection{Análise químico-bromatológica das silagens}

A análise do teor de cinzas $(\mathrm{CZ})$ ocorreu seguindo o método da Association of Official Agricultural Chemists (AOAC, 1980). As análises dos teores de proteína bruta foram obtidas através da combustão das amostras segundo o método de Dumas, utilizando-se um auto-analisador de nitrogênio, marca LECO ${ }^{\circledR}$, modelo FP-528 (Wiles et al., 1998). Os teores de fibra insolúveis em detergente neutros foram obtidos através do método seqüencial proposto pela ANKOM Fiber Analyser (ANKOM Technology Corporation, Fairport, NY) e descrito por Holden (1999). Os teores de fibra insolúvel em detergente ácido (FDA) e lignina (LIG) foram calculados segundo método de Van Soest et al. (1991). As digestibilidades verdadeiras in vitro da matéria seca e da matéria orgânica conforme protocolo proposto pela ANKOM Fiber Analyser (ANKOM Technology Corporation, Fairport, NY) e descrito por Holden (1999).

\subsubsection{Análise estatística dos dados}

Os dados foram analisados utilizando-se o procedimento GLM do programa estatístico SAS ${ }^{\circledR}$, versão 6.12 para Windows ${ }^{\circledR}$ (SAS, 1996).

Para efeito de comparação de médias entre tratamentos foi utilizado o teste de média dos mínimos quadrados (LS MEANS), com nível de significância de $5 \%$. 
As relações entre: densidade de massa verde (DMV) de silagem e massa de forragem retida acima da peneira de $38 \mathrm{~mm}$ (Figura 13); CE e massa de forragem retida acima da peneira de $38 \mathrm{~mm}$ (Figura 14) e produção de efluente e o teor de MS (Figura 15) foram explorados graficamente com o objetivo de sugerir tendências, resultando em equações preditas que, entretanto, não foram testadas estatisticamente.

\subsection{Resultados e Discussão}

\subsubsection{Composição químico-bromatológica das silagens}

Os resultados da composição químico-bromatológica das silagens de capim-Marandu confeccionadas com as forragens colhidas em diferentes intervalos entre cortes podem ser observadas nas Tabelas 18, 19, 20 e 21 .

\subsubsection{Teor de matéria seca das silagens}

Os resultados referentes ao teor médio de MS das silagens de capimMarandu estão apresentados na Tabela 18. Houve efeito do intervalo entre cortes $(P<0,01)$, da estação do ano $(P<0,01)$ e da interação intervalo entre cortes $x$ estação do ano $(P<0,01)$, não tendo sido verificado efeito de bloco ( $P=0,35)$. A amplitude dos teores de MS das silagens foi de $18,2 \%$ ( $T 15$, verão) a $45,7 \%$ (T30, inverno). Com relação às estações, a diferença encontrada ocorreu em virtude do teor médio de MS no inverno ter sido $202 \%$ superior ao teor médio de verão. Esse fato, provavelmente, se deveu à típica condição de déficit hídrico no solo e na forragem existente durante o período de inverno que podem ser justificados pelo regime pluviométrico existente, conforme apresentado na Tabela 2 (capítulo 3). 
Tabela 18. Teores de matéria seca, cinzas e proteína bruta das silagens de capim-Marandu, submetido a intervalos entre cortes, em duas estações do ano, verão e inverno

\begin{tabular}{llllllc}
\hline \multirow{2}{*}{ Tratamento } & \multicolumn{2}{c}{ MS $\%$} & \multicolumn{5}{c}{ CZ } \\
& & \multicolumn{5}{c}{ Verã } \\
T15 & $18,2^{\mathrm{b}}$ & $(0,59)$ & $13,4^{\mathrm{a}}$ & $(1,53)$ & $13,8^{\mathrm{a}}$ & $(0,50)$ \\
T30 & $19,6^{\mathrm{bB}}$ & $(0,59)$ & $14,1^{\mathrm{aA}}$ & $(1,53)$ & $12,6^{\mathrm{abA}}$ & $(0,50)$ \\
T45 & $18,8^{\mathrm{bB}}$ & $(0,59)$ & $11,4^{\mathrm{abA}}$ & $(1,53)$ & $11,2^{\mathrm{bA}}$ & $(0,50)$ \\
T60 & $19,5^{\mathrm{abB}}$ & $(0,59)$ & $9,5^{\mathrm{abA}}$ & $(1,53)$ & $7,6^{\mathrm{CA}}$ & $(0,50)$ \\
T90 & $20,7^{\mathrm{aB}}$ & $(0,59)$ & $7,4^{\mathrm{bB}}$ & $(1,53)$ & $6,7^{\mathrm{CB}}$ & $(0,50)$ \\
Média & $19,4^{\mathrm{B}}$ & $(0,26)$ & $11,2^{\mathrm{A}}$ & $(0,68)$ & $10,4^{\mathrm{A}}$ & $(0,22)$ \\
& & & \multicolumn{2}{c}{ Inverno } & & \\
T15 & $\mathrm{ND}$ & $\mathrm{ND}$ & $\mathrm{ND}$ & $\mathrm{ND}$ & $\mathrm{ND}$ & $\mathrm{ND}$ \\
T30 & $45,7^{\mathrm{aA}}$ & $(1,24)$ & $7,0^{\mathrm{bA}}$ & $(3,20)$ & $12,0^{\mathrm{aA}}$ & $(1,04)$ \\
T45 & $44,0^{\mathrm{aA}}$ & $(0,87)$ & $10,4^{\mathrm{abA}}$ & $(2,24)$ & $9,7^{\mathrm{abA}}$ & $(1,34)$ \\
T60 & $36,1^{\mathrm{bA}}$ & $(0,69)$ & $15,2^{\mathrm{aA}}$ & $(1,80)$ & $8,9^{\mathrm{bA}}$ & $(1,08)$ \\
T90 & $30,3^{\mathrm{cA}}$ & $(0,59)$ & $10,6^{\mathrm{abA}}$ & $(1,53)$ & $8,3^{\mathrm{bA}}$ & $(0,92)$ \\
Média & $39,0^{\mathrm{A}}$ & $\mathrm{ND}$ & $10,8^{\mathrm{A}}$ & $\mathrm{ND}$ & $9,7^{\mathrm{A}}$ & $\mathrm{ND}$ \\
\hline
\end{tabular}

${ }^{*} \mathrm{ND}$ - não determinado.

Valores entre parênteses indicam o erro padrão da média (EPM).

Médias na coluna seguidas de mesmas letras maiúsculas, nos mesmos tratamentos e em diferentes estações, não diferem entre si $(P>0,05)$.

Médias na coluna seguidas de mesmas letras minúsculas, nas mesmas estações, não diferem entre si $(P>0,05)$.

O desdobramento dos tratamentos dentro das estações demonstrou que durante o verão o padrão de comportamento do teor de MS foi exatamente o oposto daquele de inverno. No verão houve tendência de aumento no teor de MS conforme aumentou-se o intervalo entre cortes, passando de 18,2\% (T15) para 20,7\% (T90). Apesar de forragens colhidas em estádio de maturação fisiológica inicial (T15) poderem apresentar maiores teores de MS nas folhas 
que nas suas hastes (não avaliado), em geral, esse comportamento é inverso para as forragens mais maduras (T90), onde a haste, reconhecidamente, ao senescer também perde umidade mais intensamente que suas folhas. $O$ comportamento encontrado no presente trabalho assemelha-se ao obtido por Coan et al. (2001) para silagens de capim-Tanzânia e capim-Mombaça, conforme aumentou-se o intervalo entre cortes de 45 para 60 dias o teor de MS passou-se de $25,5 \%$ para $28,0 \%$ em média nas espécies estudadas.

Durante $\mathrm{o}$ inverno as silagens confeccionadas com forragens colhidas em intervalos de cortes crescentes apresentaram declínio nos teores de MS, o que contrariou as expectativas. Deve-se ressaltar que a tendência de decréscimo dos teores de MS nos tratamentos de inverno poderia ser resultante da aleatoriedade das datas de corte, dos mesmos, dentro da estação. Essa afirmação é particularmente importante para T60 e T90 que, antes da data de ensilagem (18/07/2002), foram colhidos, respectivamente, em 23/05/2002 e 25/04/2002, períodos em que o déficit hídrico foi marcante (Tabela 2). Esse fato sugere que as forragens utilizadas nos tratamentos T60 e T90 refletem condições particulares de um momento específico da estação de crescimento, não representando a média ponderal, em função das baixas freqüências de corte da forragem a que foram submetidas.

Observa-se na Tabela 10 (capítulo 3) que a forragem de inverno não apresentou teor de MS tão elevado quanto àquele observado para as silagens, sugerindo, com isso, que as condições climáticas poderiam ter influenciado na taxa de desidratação da forragem colhida. No dia da ensilagem a condição predominante era de sol e vento muito intensos $\left(3,4 \mathrm{~m} \mathrm{~s}^{-1}\right)$ e, por se tratar de inverno, a umidade relativa do ar era baixa (59\%), o que poderia ter provocado a elevação do teor de MS encontrado, especialmente, nos tratamentos com menor estádio de maturidade, devido à maior presença de folhas.

As diferenças entre estações refletem, provavelmente, as mudanças climáticas que ocorrem no período de inverno, relacionadas ao fotoperíodo, temperatura ambiente, precipitação e déficit hídrico. Igarasi (2002) também 
verificou diferenças, embora menores, entre as estações do ano no tocante teor de MS de silagens de capim tropical. O teor de MS encontrado por Igarasi (2002) nas silagens contendo exclusivamente a forragem original, foi mais baixo que a do presente trabalho, e isso pode ser justificado pela diferença entre espécies, uma vez que naquele estudo foi avaliado o capim-Tanzânia.

\subsubsection{Teor de cinzas das silagens}

Os resultados referentes ao teor médio de $C Z$ das silagens de capimMarandu estão apresentados na Tabela 18. Houve efeito da interação intervalo entre cortes $x$ estação do ano $(P<0,05)$, não tendo sido verificado efeito do intervalo entre cortes $(P=0,18)$, da estação do ano $(P=0,89)$ e de bloco ( $P=0,35$ ). $O$ teor de $C Z$ variou de 7,0\% (T30, inverno) a 15,2\% (T60, inverno).

Analisando-se os tratamentos dentro das estações nota-se que durante os cortes de verão houve padrão de decréscimo no teor de CZ com o avanço do estádio de maturidade. Essa tendência maiores teores de $\mathrm{CZ}$ em forragens colhidas precocemente segue dados encontrados em literatura (Castro, 1997; Gomide, 1976 e Haag, 1984), embora no presente trabalho tenham sido encontrados valores relativamente elevados, o que leva a crer que tenha ocorrido contaminação da forragem, por solo, no momento da colheita para ensilagem. Além disso, deve-se considerar que as perdas de sólidos solúveis no processo de ensilagem, em geral, promoveram concentração da fração de minerais na silagem, conforme descrito por Van Soest (1994). Nas silagens confeccionadas no inverno o único tratamento que diferiu dos demais foi o T30, surpreendentemente originado de uma forragem mais jovem com baixo teor de CZ, não havendo amparo na literatura para a explicação dessa ocorrência. 


\subsubsection{Teor de proteína bruta das silagens}

Os resultados referentes ao teor médio de PB das silagens de capimMarandu estão apresentados na Tabela 18. Houve efeito do intervalo entre cortes $(P<0,01)$, de bloco $(P<0,01)$ e da interação intervalo entre cortes $x$ estação do ano $(P<0,05)$, não tendo sido verificado efeito da estação do ano $(\mathrm{P}=0,66)$. A amplitude dos teores de $\mathrm{PB}$ ao longo do período experimental foi de $6,7 \%$ (T90, verão) a 13,8\% (T15, verão). Em relação às estações do ano, as médias obtidas para os teores de PB foram de $10,4 \%$ no verão e de $9,7 \%$ de PB no inverno.

O desdobramento da interação mostra que os tratamentos dentro das estações seguiram um mesmo padrão decrescente à medida que se distanciou o intervalo entre cortes. Esse fato era esperado, pois, como já discutido previamente na seção 3.3.3.2 (capítulo 3), a grande participação de folhas, que contém maiores teores de PB e outros componentes digestíveis, determinaria também para as silagens maiores teores de PB. Estes resultados corroboraram com os encontrados por Silveira et al. (1974) e Narciso Sobrinho (1998), que avaliaram silagens de capim-elefante. Andrade et al. (1994) também encontraram mesma tendência em fenos de $B$. decumbens e capim-Marandu que tiveram os valores de PB decrescidos à medida que o intervalo entre cortes foi prolongado. Entretanto, Ribeiro et al. (2002), trabalhando com silagens de $B$. decumbens submetidas a diferentes idades de corte, observaram que as mesmas apresentaram resposta quadrática em relação ao teor de $\mathrm{PB}$, com pico aos 56 dias $(7,6 \%)$.

No presente estudo apenas o T90 de verão apresentou teor absoluto de PB menor que a média de silagens de Brachiaria sp. (7,0\% PB), encontradas em diversas propriedades, conforme relatado em revisão por Nussio et al. (2000).

No desdobramento das estações dentro dos tratamentos pôde-se observar, na Tabela 18, que o tratamento T90 apresentou maior valor de PB no 
inverno que no verão, enquanto os outros tratamentos não diferiram entre si. Essa tendência também foi relatada por Gerdes et al. (2000b) trabalhando com capim-Marandu, cortado aos 35 dias de rebrotação e, segundo os autores esse fato deve-se, provavelmente, ao elevado teor de FDN (Tabela 19) encontrado nesse tratamento durante o verão, decorrente da significativa participação da haste na composição da MS da forragem (Tabela 7).

\subsubsection{Teor de fibra insolúvel em detergente neutro das silagens}

Os resultados referentes ao teor médio de FDN das silagens de capimMarandu estão apresentados na Tabela 19. Houve efeito do intervalo entre cortes $(P<0,01)$ e da estação do ano $(P<0,01)$, não tendo sido verificado efeito da interação intervalo entre cortes $x$ estação do ano $(P=0,15)$ e de bloco $(\mathrm{P}=0,08)$. A amplitude dos teores de FDN variou de $56,6 \%$ (T30 de inverno) a $74,7 \%$ (T90 de verão).

O desdobramento dos intervalos entre cortes dentro das estações mostra consistentemente aumento dos teores de FDN com o prolongamento no intervalo entre cortes. Esse comportamento não foi verificado por Coan et al. (2001) nas silagens de capim-Tanzânia e capim-Mombaça com 45 e 60 dias de crescimento vegetativo.

Os resultados encontrados quanto aos teores de FDN das silagens segue a tendência encontrada para as forragens (Tabela 12) nas estações do ano e, contrariando a expectativa uma vez que, segundo McDonald et al. (1991), o processo de ensilagem não melhora a composição química da forragem, mas visa mantê-la estável por mais tempo incidindo com perdas sob diferentes intensidades. Essa variação estacional do FDN das silagens, 67,9\% no verão e $60,2 \%$ no inverno, pode ser explicada pela teoria proposta por Buxton \& Fales (1994). Segundo esses autores as reações que dão origem à síntese dos constituintes de parede celular são mediadas por enzimas e a elevação da temperatura é condicionante na concentração de vários 
precursores enzimáticos. Efeito similar relacionado às estações do ano foi encontrado por Igarasi (2002) em silagens de capim-Tanzânia, relatando teores de FDN de $63,5 \%$ no inverno e $67,5 \%$ no verão, valores próximos aos observados no presente estudo.

Tabela 19. Teores de fibra insolúvel em detergente neutro e fibra insolúvel em detergente ácido das silagens de capim-Marandu, submetido a intervalo entre cortes, em duas estações do ano, verão e inverno

\begin{tabular}{llccc}
\hline Tratamento & \multicolumn{3}{c}{ FDN } & \multicolumn{3}{c}{ FDA } \\
& & \multicolumn{3}{c}{ Verão } \\
T15 & $63,6^{\mathrm{d}}$ & $(0,98)$ & $32,6^{\mathrm{C}}$ & $(0,95)$ \\
T30 & $64,4^{\mathrm{cdA}}$ & $(0,98)$ & $33,1^{\mathrm{cA}}$ & $(0,95)$ \\
T45 & $66,5^{\mathrm{cA}}$ & $(0,98)$ & $35,1^{\mathrm{AA}}$ & $(0,95)$ \\
T60 & $70,1^{\mathrm{bA}}$ & $(0,98)$ & $39,7^{\mathrm{bA}}$ & $(0,95)$ \\
T90 & $74,7^{\mathrm{aA}}$ & $(0,98)$ & $45,6^{\mathrm{aA}}$ & $(0,95)$ \\
Média & $67,9^{\mathrm{A}}$ & $(0,44)$ & $37,2^{\mathrm{A}}$ & $(0,43)$ \\
& & & & \\
T15 & $\mathrm{ND}$ & $\mathrm{ND}$ & $\mathrm{ND}$ & $\mathrm{ND}$ \\
T30 & $56,6^{\mathrm{bB}}$ & $(2,05)$ & $30,1^{\mathrm{aA}}$ & $(2,00)$ \\
T45 & $59,6^{\mathrm{abB}}$ & $(1,43)$ & $30,8^{\mathrm{aB}}$ & $(1,40)$ \\
T60 & $61,9^{\mathrm{aB}}$ & $(1,15)$ & $30,1^{\mathrm{aB}}$ & $(1,12)$ \\
T90 & $62,9^{\mathrm{aB}}$ & $(0,98)$ & $33,5^{\mathrm{aB}}$ & $(0,95)$ \\
Média & $60,2^{\mathrm{B}}$ & $\mathrm{ND}$ & $31,1^{\mathrm{B}}$ & $\mathrm{ND}$ \\
\hline
\end{tabular}

${ }^{*} \mathrm{ND}$ - não determinado.

Valores entre parênteses indicam o erro padrão da média (EPM).

Médias na coluna seguidas de mesmas letras maiúsculas, nos mesmos tratamentos e em diferentes estações, não diferem entre si $(P>0,05)$.

Médias na coluna seguidas de mesmas letras minúsculas, nas mesmas estações, não diferem entre si $(P>0,05)$. 
Os resultados encontrados neste experimento foram inferiores aos apresentados em revisão por Nussio et al. (2000) que relataram teores médios de FDN de 77,7\% para silagens de capim-Marandu de várias fazendas da região Centro-Oeste do país. Bernardes (2003) encontrou, em silagens de capim-Marandu colhido aos 58 dias no verão, teor de FDN médio de $70 \%$, que se assemelha aos achados no presente trabalho.

\subsubsection{Teor de fibra insolúvel em detergente ácido das silagens}

Os resultados referentes ao teor médio de FDA das silagens de capimMarandu estão apresentados na Tabela 19. Houve efeito do intervalo entre cortes $(P<0,01)$ e da estação do ano $(P<0,01)$ e da interação intervalo entre cortes $x$ estação do ano $(P<0,01)$, não tendo sido verificado efeito de bloco $(P=0,44)$. A amplitude de valores de FDA ficou situada entre 30,1\% (T30 e T60 de inverno) e 45,6\% (T90 de verão). As médias dos teores de FDA para as estações do ano foram de $37,2 \%$ no verão e $31,1 \%$ no inverno.

Desdobrando-se os tratamentos dentro das estações do ano notou-se que, no verão, o comportamento foi semelhante ao observado para o FDN, com aumento progressivo do teor de FDA conforme o intervalo entre cortes foi distanciado. Até os 60 dias de crescimento vegetativo não houve elevação no teor de FDA. Esse fato está de acordo com a variação ocorrida em composição morfológica da forragem (Tabelas 6, 7 e 9 e Figura 3, capítulo 3). Coan et al. (2001), estudando com silagens de capim-Tanzânia e capim-Mombaça no verão, também verificaram aumentos no teor de FDA (44,5\% para $48,0 \%)$ à medida que se prolongou o intervalo entre cortes de 45 para 60 dias. No inverno, em oposição ao observado no FDN, não foram encontradas diferenças para os teores de FDA entre os tratamentos, sugerindo alterações exclusivamente associadas à fração hemicelulose.

A diferença entre as estações, encontradas nos teores de FDA, assim como ocorrida para o FDN, pode ser justificada pela teoria de Buxton \& Fales 
(1994), já discutida na secção anterior (4.3.1.4). Os resultados encontrados no presente experimento resultaram em teores médios de FDA de $37,2 \%$ no verão e $31,1 \%$ no inverno, que são inferiores aos obtidos por Bernardes (2003), cuja média foi de $46,5 \%$ e àqueles relatados por Nussio et al. (2000), que atingiram $51,6 \%$. Podendo, assim, afirmar que as silagens confeccionadas, no presente estudo, apresentaram melhor valor nutritivo, no tocante às frações da fibra, que aquelas encontradas em diversas propriedades da região centro-oeste brasileira. Igarasi (2002) encontrou teores de FDA, em silagens de capimTanzânia, de $45,9 \%$ no verão e $38,5 \%$ no inverno.

\subsubsection{Teor de hemicelulose das silagens}

Os resultados referentes ao teor médio de hemicelulose (HEM) das silagens de capim-Marandu estão apresentados na Tabela 20. Houve efeito de bloco $(P<0,01)$, não tendo sido verificado efeito do intervalo entre cortes $(P=0,33)$, da estação do ano $(P=0,10)$ e da interação intervalo entre cortes $x$ estação do ano $(P=0,09)$. O teor de HEM variou de $26,5 \%$ (T30, inverno) a $31,7 \%$ (T60, inverno), corroborando com a amplitude, sugerida por McDonald et al. (1991), de 10 a 30\% na MS.

Manno et al. (2002) encontraram 36,6\% de HEM em silagens de capimCoastcross com 45 dias de rebrotação, um valor mais elevado que o obtido no presente experimento. Coan et al. (2001), avaliando silagens de capins do gênero Panicum, encontraram maiores teores de hemicelulose quando a forragem foi colhida aos 45 dias de rebrotação $(31,7 \%)$ em relação àquelas colhidas aos 60 dias $(27,4 \%)$. No presente experimento não foi observado efeito de intervalo entre cortes no teor de HEM, contudo, a relação HEM:FDN (dados não apresentados) tende a decrescer com a maior freqüência de cortes, especialmente no verão, quando apresentou declínio de 20,1\% entre T15 e T90. 
Para Igarasi (2002), os teores médios de hemicelulose em silagens de capim-Tanzânia foram de $21,7 \%$ e $24,9 \%$, respectivamente, no verão e no inverno. Apesar de não ter havido efeito de estação do ano $(P=0,10)$ e da interação tratamento $x$ estação do ano $(P=0,09)$ para a fração hemicelulose, a variação intrínseca dos dados permite inferir sobre a tendência de aumento nos teores de HEM com o prolongamento do intervalo entre cortes no período de inverno. Esse fato corrobora com as alterações anteriormente relatadas na seção 4.3.1.5 e sugere comportamentos distintos para a síntese de hemicelulose sob diferentes regimes climáticos associados às estações do ano.

Quando comparados os teores de HEM das forragens (Tabela 15), aqueles encontrados em suas respectivas silagens (Tabela 20), apresentaramse inferiores. Esse efeito havia sido anteriormente reportado por Crestana et al. (2001), que constataram que a fração HEM contribuiu efetivamente como substrato para a fermentação da silagem de capim-Tanzânia. De acordo com McDonald et al. (1991) a hidrólise da hemicelulose pode ser realizada por hemicelulases provenientes da forragem, de microrganismos e também por ácidos orgânicos produzidos durante a fermentação. Ainda segundo esses autores, a quantidade desses ácidos durante o processo fermentativo é, geralmente, maior que a respectiva disponibilidade de carboidratos solúveis, sugerindo que outros substratos como proteínas, aminoácidos, ácido lático e, principalmente, carboidratos estruturais, podem ser utilizados como suprimento aos microrganismos.

\subsubsection{Teor de celulose das silagens}

Os resultados referentes ao teor médio de celulose $(C E L)$ das silagens de capim-Marandu estão apresentados na Tabela 20. Houve efeito do intervalo entre cortes $(P<0,01)$, da estação do ano $(P<0,01)$ e da interação intervalo entre cortes $x$ estação do ano $(P<0,05)$, não tendo sido verificado efeito de bloco $(\mathrm{P}=0,47)$. A amplitude dos teores de CEL variou entre $25,7 \%$ (T60 de inverno) e 
39,5\% (T90 de verão). O teor médio de CEL no verão $(33,1 \%)$ foi maior que o observado no inverno $(27,0 \%)$.

Tabela 20. Teores de hemicelulose, celulose e lignina das silagens de capimMarandu, submetido a intervalos entre cortes, em duas estações do ano, verão e inverno

\begin{tabular}{|c|c|c|c|c|c|c|}
\hline \multirow{2}{*}{ Tratamento } & \multicolumn{2}{|c|}{ HEM } & \multicolumn{2}{|c|}{ CEL } & \multicolumn{2}{|c|}{ LIG } \\
\hline & \multicolumn{6}{|c|}{ Verão } \\
\hline T15 & $31,0^{a}$ & $(0,92)$ & $29,1^{\mathrm{c}}$ & $(0,91)$ & $3,4^{\mathrm{c}}$ & $(0,15)$ \\
\hline T30 & $31,3^{\mathrm{aA}}$ & $(0,92)$ & $29,7^{\mathrm{cA}}$ & $(0,91)$ & $3,2^{\mathrm{cB}}$ & $(0,15)$ \\
\hline T45 & $31,4^{\mathrm{aA}}$ & $(0,92)$ & $31,7^{\mathrm{cA}}$ & $(0,91)$ & $3,3^{\mathrm{cB}}$ & $(0,15)$ \\
\hline T60 & $30,4^{\mathrm{aA}}$ & $(0,92)$ & $35,6^{\mathrm{bA}}$ & $(0,91)$ & $4,0^{\mathrm{bA}}$ & $(0,15)$ \\
\hline T90 & $29,1^{\mathrm{aA}}$ & $(0,92)$ & $39,5^{\mathrm{aA}}$ & $(0,91)$ & $6,1^{\mathrm{aA}}$ & $(0,15)$ \\
\hline \multirow[t]{2}{*}{ Média } & $30,6^{A}$ & $(0,41)$ & $33,1^{\mathrm{A}}$ & $(0,41)$ & $4,0^{\mathrm{A}}$ & $(0,06)$ \\
\hline & \multicolumn{6}{|c|}{ Inverno } \\
\hline T15 & $N D^{*}$ & ND & ND & ND & ND & ND \\
\hline T30 & $26,5^{\mathrm{bB}}$ & $(1,92)$ & $26,0^{\mathrm{abA}}$ & $(1,91)$ & $4,2^{\mathrm{aA}}$ & $(0,31)$ \\
\hline T45 & $28,8^{a b A}$ & $(1,34)$ & $27,0^{\mathrm{abB}}$ & $(1,34)$ & $3,9^{\mathrm{aA}}$ & $(0,21)$ \\
\hline T60 & $31,7^{\mathrm{aA}}$ & $(1,08)$ & $25,7^{\mathrm{bB}}$ & $(1,07)$ & $4,3^{\mathrm{aA}}$ & $(0,17)$ \\
\hline T90 & $29,4^{\mathrm{abA}}$ & $(0,92)$ & $29,4^{\mathrm{aB}}$ & $(0,91)$ & $4,2^{\mathrm{aB}}$ & $(0,15)$ \\
\hline Média & $29,1^{\mathrm{A}}$ & ND & $27,0^{\mathrm{B}}$ & ND & $4,1^{\mathrm{A}}$ & ND \\
\hline
\end{tabular}

${ }^{*} \mathrm{ND}$ - não determinado.

Valores entre parênteses indicam o erro padrão da média (EPM).

Médias na coluna seguidas de mesmas letras maiúsculas, nos mesmos tratamentos e em diferentes estações, não diferem entre si $(P>0,05)$.

Médias na coluna seguidas de mesmas letras minúsculas, nas mesmas estações, não diferem entre si $(P>0,05)$.

O desdobramento dos intervalos entre cortes dentro das estações de verão e inverno demonstrou tendência de aumentos nos teores de CEL com o aumento no intervalo entre cortes nas duas estações. Esse resultado é 
semelhante ao obtido por Coan et al. (2001), que avaliaram silagens de capimTanzânia e capim-Mombaça colhidas aos 45 e 60 dias de rebrotação e encontraram valores médios das duas espécies de $34,5 \%$ e $36,3 \%$, respectivamente. No presente experimento, também foi observado aumento de 15,3\% na relação CEL:FDN (dados não apresentados) com o maior intervalo entre cortes (T90) em relação ao corte mais freqüente (T15), durante o verão.

Com relação às estações do ano a mesma teoria (Buxton \& Fales, 1994) aplicada aos teores de FDN e FDA explica os maiores valores de CEL no verão que no inverno. Tendo em vista o exposto pode-se inferir que a alteração da fração CEL tenha sido, possivelmente, a principal responsável pelas mudanças nos teores de FDN entre estações, pois além das frações HEM e LIG que não se alteraram significativamente (Tabela 20), também compõem o FDN, as frações sílica e cutina, as quais têm participação diminuta (Van Soest, 1994).

Segundo Van Soest (1994), a celulose se mantém estável durante a fermentação no interior do silo e isso pôde ser confirmado através dos teores de CEL das forragens (Tabela 15) e das silagens (Tabela 20) que não apresentaram grande variação entre eles. Contudo, Reis \& Jobim (2001) relataram que uma pequena porção (menos de $5 \%$ ) da fração celulose tem sido degradada pelo efeito de enzimas fibrolíticas.

\subsubsection{Teor de lignina das silagens}

De acordo com Van Soest (1994) a lignina, assim com a celulose, mantém-se estável durante o processo fermentativo e parte dessas frações são degradadas apenas quando há presença de fungos portadores de ligninase. Ainda, segundo esse autor a lignina é o principal fator que limita a exposição da parede celular das plantas, restringindo a digestão do polímero pelos animais.

Os resultados referentes ao teor médio de lignina das silagens de capimMarandu estão apresentados na Tabela 20. Houve efeito do intervalo entre cortes $(P<0,01)$ e da interação intervalo entre cortes $x$ estação do ano $(P<0,01)$, 
não tendo sido verificado efeito da estação do ano $(P=0,95)$ e de bloco $(P=0,78)$. O mínimo teor de LIG encontrado foi de 3,2\% (T30 durante o verão) e o máximo foi de $6,1 \%$ (T90 durante o inverno).

O desdobramento de intervalos entre cortes dentro das estações revelou que, durante o verão, não houve variação nos teores de LIG nas silagens confeccionadas com forragem com até 45 dias de rebrotação, com elevação a partir desse ponto (Tabela 20). Em silagens de capins do gênero Panicum, Coan et al. (2001) encontraram a mesma tendência com maiores teores de LIG na silagem de capins colhidos aos 60 dias de rebrotação em relação àqueles colhidos aos 45 dias. No presente experimento o tratamento T90 de verão apresentou um acentuado acúmulo de LIG, sendo que quando o intervalo entre cortes passou de 60 para 90 dias houve acréscimo médio de $50 \%$ no teor de LIG. A análise da relação LIG:FDN (dados não apresentados) demonstrou tendência de aumento de 64,2\% entre T15 e T90, durante o verão, sugerindo o menor potencial de digestão da parede celular em forragens senescentes. $O$ teor de LIG encontrado aos 60 dias na estação de verão foi menor que aquele encontrado por Bernardes (2003) em silagens de capim-Marandu confeccionadas com forragens colhidas aos 58 dias de maturidade durante 0 verão, cujo valor médio de LIG foi de 5,0\%.

\subsubsection{Digestibilidade verdadeira in vitro da matéria seca das silagens}

Os resultados referentes à DVIVMS das silagens de capim-Marandu estão apresentados na Tabela 21. Houve efeito do intervalo entre cortes $(P<0,01)$, da estação do ano $(P<0,01)$, da interação intervalo entre cortes $x$ estação do ano $(\mathrm{P}<0,01)$ e de bloco $(\mathrm{P}<0,05)$. A amplitude dos valores do coeficiente de DVIVMS foi de 48,7\% (T90 de verão) a 64,4\% (T30 de inverno). Com relação às estações do ano as médias dos coeficientes de DVIVMS de verão e de inverno foram de $58,5 \%$ e $60,7 \%$, respectivamente. 
Tabela 21. Digestibilidade verdadeira in vitro da matéria seca, digestibilidade verdadeira in vitro da matéria orgânica e pH das silagens de capimMarandu, submetido a intervalos entre cortes, em duas estações do ano, verão e inverno

\begin{tabular}{|c|c|c|c|c|c|c|}
\hline \multirow{2}{*}{ Tratamento } & \multicolumn{2}{|c|}{ DVIVMS } & \multicolumn{2}{|c|}{ DVIVMO } & \multicolumn{2}{|c|}{$\mathrm{pH}$} \\
\hline & \multicolumn{6}{|c|}{ Verão } \\
\hline T15 & $60,5^{\mathrm{b}}$ & $(0,90)$ & $59,5^{b}$ & $(1,10)$ & $5,6^{a}$ & $(0,15)$ \\
\hline T30 & $62,8^{\mathrm{abA}}$ & $(0,90)$ & $64,8^{\mathrm{aA}}$ & $(1,10)$ & $4,9^{\mathrm{bA}}$ & $(0,15)$ \\
\hline T45 & $63,9^{\mathrm{aA}}$ & $(0,90)$ & $63,3^{\mathrm{aA}}$ & $(1,10)$ & $5,0^{\mathrm{bA}}$ & $(0,15)$ \\
\hline T60 & $56,4^{\mathrm{cA}}$ & $(0,90)$ & $55,2^{\mathrm{CB}}$ & $(1,10)$ & $4,7^{\mathrm{bA}}$ & $(0,15)$ \\
\hline T90 & $48,7^{\mathrm{dB}}$ & $(0,90)$ & $46,6^{\mathrm{dB}}$ & $(1,10)$ & $4,7^{\mathrm{bA}}$ & $(0,15)$ \\
\hline \multirow[t]{2}{*}{ Média } & $58,5^{\mathrm{B}}$ & $(0,40)$ & $57,9^{\mathrm{B}}$ & $(0,49)$ & $5,0^{A}$ & $(0,07)$ \\
\hline & \multicolumn{6}{|c|}{ Inverno } \\
\hline T15 & $N D^{*}$ & ND & ND & ND & ND & ND \\
\hline T30 & $64,4^{\mathrm{aA}}$ & $(1,88)$ & $63,2^{\mathrm{aA}}$ & $(2,32)$ & $4,9^{\mathrm{aA}}$ & $(0,32)$ \\
\hline T45 & $60,6^{\mathrm{abA}}$ & $(1,32)$ & $60,4^{\mathrm{aA}}$ & $(1,63)$ & $4,9^{\mathrm{aA}}$ & $(0,22)$ \\
\hline T60 & $59,0^{\mathrm{bA}}$ & $(1,06)$ & $60,7^{\mathrm{aA}}$ & $(1,30)$ & $4,5^{\mathrm{aA}}$ & $(0,18)$ \\
\hline T90 & $59,0^{\mathrm{bA}}$ & $(0,90)$ & $59,1^{\mathrm{aA}}$ & $(1,10)$ & $4,6^{\mathrm{aA}}$ & $(0,15)$ \\
\hline Média & $60,7^{A}$ & ND & $60,8^{A}$ & ND & $4,7^{\mathrm{A}}$ & ND \\
\hline
\end{tabular}

${ }^{*} \mathrm{ND}$ - não determinado.

Valores entre parênteses indicam o erro padrão da média (EPM).

Médias na coluna seguidas de mesmas letras maiúsculas, nos mesmos tratamentos e em diferentes estações, não diferem entre si $(P>0,05)$.

Médias na coluna seguidas de mesmas letras minúsculas, nas mesmas estações, não diferem entre si $(P>0,05)$.

Em virtude da possível contaminação, por solo, da forragem colhida para ensilagem, como anteriormente sugerido na seção 4.3.1.2, a discussão da digestibilidade será realizada em função da matéria orgânica, a qual apresentou padrão comportamental semelhante à da DVIVMS, entretanto, se traduziu em 
valores mais estáveis pela ausência da interferência do componente mineral (CZ).

\subsubsection{Digestibilidade verdadeira in vitro da matéria orgânica das silagens}

Os resultados referentes à DVIVMO das silagens de capim-Marandu estão apresentados na Tabela 21. Houve efeito do intervalo entre cortes $(P<0,01)$, da estação do ano $(P<0,01)$ e da interação intervalo entre cortes $x$ estação do ano $(P<0,01)$, não tendo sido verificado efeito de bloco $(P=0,13)$. Os valores máximos e mínimos encontrados nas DVIVMO foram, respectivamente, 46,6\% (T90, verão) e 64,8\% (T30, verão). O coeficiente de DVIVMO foi menor no verão $(57,9 \%)$ que no inverno $(60,8 \%)$.

Houve tendência para maiores valores de DVIVMS em relação aos de DVIVMO, sugerindo que os minerais contidos nesses tratamentos apresentam solubilidade superior à matéria orgânica (MO) das silagens. Fato semelhante havia sido observado por Castro (1997) e por Vieira (1998), apesar de apresentaram tendência oposta ao tradicionalmente reportado na literatura (Van Soest, 1994).

No desdobramento dos diferentes intervalos entre cortes nas estações notou-se que durante o verão houve declínio na DVIVMO do T30 ao T90, sendo que no T15 ocorreu um comportamento atípico, resultando em um coeficiente de DVIVMO menor que no tratamento T30 provavelmente justificado pela contaminação de material senescente. O decréscimo na DVIVMO com o avanço do estádio de maturidade decorre do fato que os teores de componentes digestíveis (conteúdo celular) decrescem com o avanço da maturidade, enquanto a parede celular tende a se espessar e participar de forma mais pronunciada como componente da MS. Pôde-se observar na Tabela 21 que a redução na digestibilidade tornou-se mais acentuada a partir dos 60 dias de crescimento vegetativo devido, sobretudo, aos significativos aumentos 
nos teores de FDN, FDA, CEL e LIG encontrados nesse tratamento e em intervalos entre cortes mais prolongados. Segundo Van Soest (1994) a presença de lignina protege os carboidratos estruturais da ação dos microrganismos e se intensifica durante o espessamento da parede celular. $\mathrm{O}$ efeito de expansão no intervalo entre cortes determinou decréscimos nas digestibilidades, tanto da MS quanto da $\mathrm{MO}$, tem sido relatado por diversos autores (Acunha \& Coelho, 1997 e Alcântara et al., 1981). Contudo, Coan et al. (2001) não encontraram diferenças na DIVMS das silagens de capins Tanzânia e Mombaça colhidos aos 45 e 60 dias de rebrotação. No inverno, os coeficientes de DVIVMO das silagens não diferenciaram-se entre si, tendo apresentado amplitude de variação entre $59,1 \%$ e 63,2\%.

Os coeficientes médios de DVIVMO encontrados no presente trabalho foram superiores àqueles relatados por Nussio et al. (2000) (50,7\% de DIVMS) para as silagens de capim-Marandu e os encontrados por Bernardes (2003), também com capim-Marandu ( $45 \%$ de DIVMS).

A Tabela 21 mostra maior coeficiente de digestibilidade no inverno e esse fato revela que o efeito poderia ter sido influenciado mais pelos componentes de parede celular (FDN, FDA, CEL) que, propriamente, pelos componentes mais digestíveis ou solúveis (PB e CZ), pois entre as estações do ano não houve diferença nos teores de PB e CZ (Tabela 18), entretanto, as estações do ano apresentaram importantes alterações nos teores de FDN, FDA e celulose (Tabelas 19 e 20).

\subsubsection{1 $\mathrm{pH}$ das silagens}

Os resultados referentes ao valor médio do $\mathrm{pH}$ das silagens de capimMarandu estão apresentados na Tabela 21. Houve efeito do intervalo entre cortes $(P<0,01)$ e de bloco $(P<0,05)$, não tendo sido verificado efeito da estação do ano $(P=0,61)$ e da interação intervalo entre cortes $x$ estação do ano 
( $\mathrm{P}=0,98)$. Os valores de $\mathrm{pH}$ variaram de 4,5 (T60 de inverno) a 5,6 (T15 de verão).

Os valores de $\mathrm{pH}$ encontrados no presente experimento foram muito superiores aos preconizados pela literatura para silagens de milho e sorgo, com bom processo fermentativo. No entanto, pHs mais elevados $(>5,0)$ têm sido comumente encontrados em silagens de capins tropicais, em especial sob condições de limitação de carboidratos solúveis ou elevado poder tampão. Narciso Sobrinho (1998) encontrou, em silagens de capim-elefante, submetido a diferentes tratamentos, em três idades de rebrotação, valores de $\mathrm{pH}$ não superiores a 3,6. Todavia, Aguiar et al. (2001) encontraram valores de pH tão elevados quanto aos apresentados no presente trabalho, sendo de 5,6, 4,9 e 4,9 para silagens de capim-Tanzânia aditivadas com 0, 5 e 10\% de polpa cítrica peletizada, respectivamente.

Nas silagens de verão verificou-se que o tratamento T15 diferiu dos demais e apresentou valor de $\mathrm{pH}$ mais elevado e, esse fato, pode ser devido à fermentação indesejável, sobretudo àquela ocorrida por meio de Clostridium sp. Considerando a possível contaminação ocorrida por solo, conforme constatado pelo elevado teor de CZ na silagem (Tabela 17 e seção 4.3.1.2); associada ao baixo teor de MS observado no T15, sugere-se que as condições estiveram propícias ao estabelecimento desses microorganismos. $\mathrm{O}$ fato do maior teor de MS propiciar silagens com $\mathrm{pH}$ mais baixo também foi comprovado por Igarasi (2002) avaliando silagens de capim-Tanzânia emurchecidas (30\% MS).

\subsubsection{Aspectos físicos das silagens}

Os resultados relativos aos aspectos físicos silagens de capim-Marandu confeccionadas com as forragens colhidas em diferentes intervalos entre cortes podem ser observadas nas Tabelas 22, 23 e 24. 


\subsubsection{Tamanho de partícula das silagens}

O tamanho de partícula afeta diretamente vários fatores como densidade da massa a ser ensilada, produção de efluentes e gases, e conseqüentemente, influencia no processo fermentativo (Balsalobre et al., 2001 e Igarasi, 2002).

Os resultados referentes ao tamanho médio das partículas das silagens de capim-Marandu estão apresentados na Tabela 22. Houve efeito do intervalo entre cortes $(P<0,01)$ e da interação intervalo entre cortes $x$ estação do ano $(P<0,01)$, não tendo sido verificado efeito da estação do ano $(P=0,96)$ e de bloco $(P=0,06)$. A amplitude dos valores de tamanho médio das partículas ficou entre $31 \mathrm{~mm}$ (T15 e T30 de verão) e 36 mm (T60, T90 de verão e T30 de inverno) e, portanto, os valores encontrados estão de acordo com os propostos por Lavezzo (1985), cuja recomendação para a trituração da forragem, visando a ensilagem, deveria procurar obter tamanho médio de partículas de 30-50 mm, para permitir uma melhor compactação e, por conseguinte, assegurar $o$ estabelecimento do ambiente anaeróbico mais rapidamente.

Embora até os 60 dias de intervalo entre cortes não tenha havido diferença entre os tratamentos nota-se, durante o verão, aumento numérico no tamanho médio das partículas com o distanciamento do intervalo entre cortes e esse efeito foi acompanhado por aumentos dos teores de MS das silagens (Tabela 18). Isso se justifica tanto pela resistência à picagem da massa de forragem, promovida pela aumento na participação das hastes (Tabela 7 , capítulo 3), quanto pelas conseqüência do aumento nos teores das frações fibrosas (Tabelas 18 e 19).

No inverno o tamanho médio de partícula apresentou comportamento inconsistente, sendo o menor tamanho encontrado para o T60, não seguindo, assim, o mesmo comportamento do verão, estação no ano na qual houve progressivos aumentos no percentual de massa retida na peneira de maior diâmetro $(38 \mathrm{~mm})$ até ao 60 dias de crescimento vegetativo. O resultado do intervalo entre cortes sobre o tamanho das partículas, nas duas estações do 
ano, pode ser notado através da análise da Figura 12, que mostra, com isso, o efeito característico da interação entre intervalo entre cortes $x$ estação do ano.

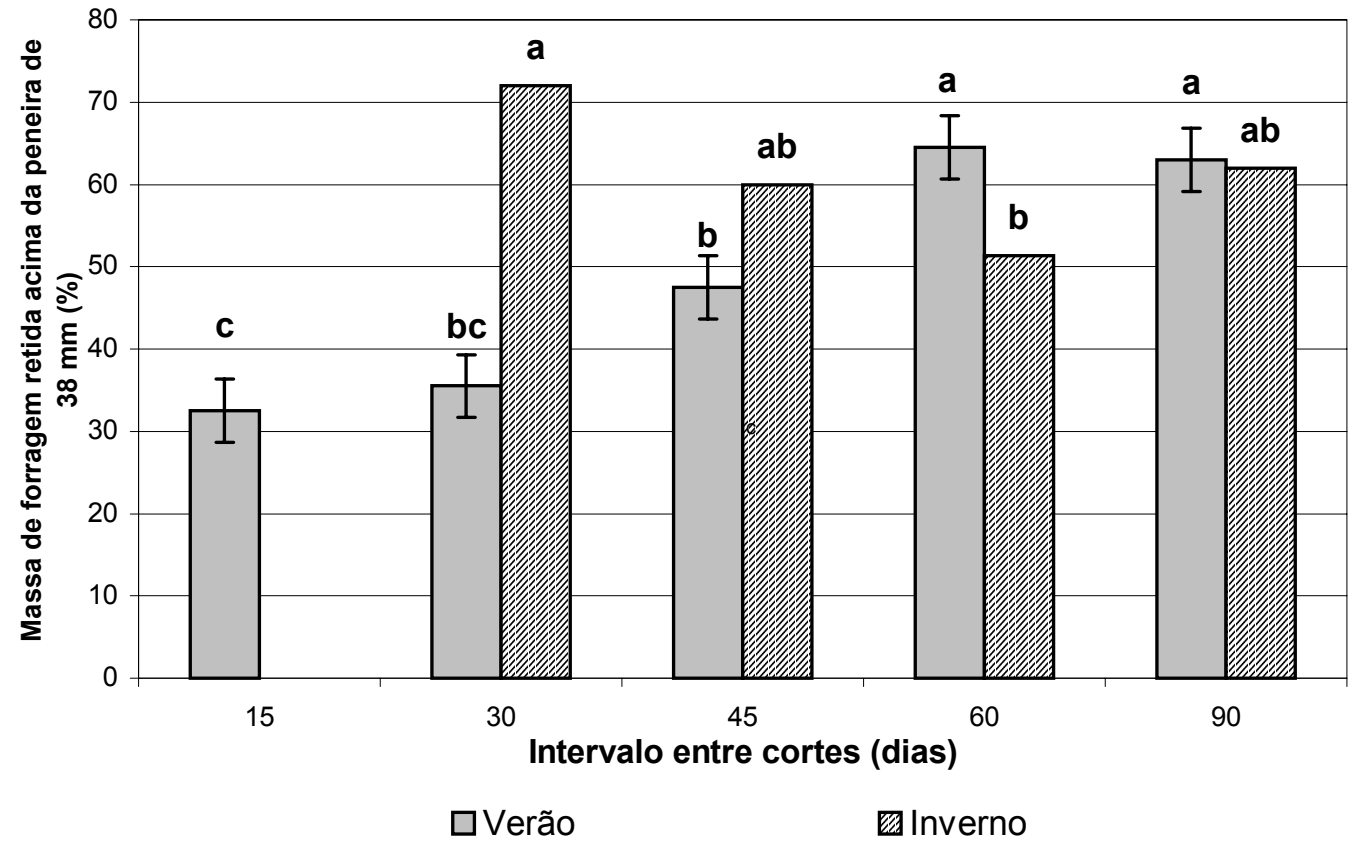

Figura 12 - Proporção da massa retida em peneira de $38 \mathrm{~mm}$ de diâmetro, nas silagens de capim-Marandu ensiladas sob intervalo de cortes, nas estações de verão e inverno

\subsubsection{Densidade das silagens}

Os resultados referentes às densidades da massa verde (DMV) e da massa seca (DMS) das silagens de capim-Marandu estão apresentados na Tabela 22. Houve efeito do intervalo entre cortes $(P<0,01)$ e da estação do ano $(P<0,01)$, não tendo sido verificado efeito da interação intervalo entre cortes $x$ estação do ano $(P=0,54)$ e de bloco $(P=0,53)$ no tocante à DMV. A amplitude dos valores de DMV foi dos $442 \mathrm{~kg} \mathrm{~m}^{-3}$ (T60 no inverno) a $633 \mathrm{~kg} \mathrm{~m}^{-3}$ (T15 no 
verão). A DMV média das estações foi de $576 \mathrm{~kg} \mathrm{~m}^{-3}$ no verão e $458 \mathrm{~kg} \mathrm{~m}^{-3}$ no inverno.

Tabela 22. Densidade da matéria verde, da matéria seca e tamanho médio das partículas das silagens de capim-Marandu, submetido a intervalos entre cortes, em duas estações do ano, verão e inverno

\begin{tabular}{|c|c|c|c|c|c|c|}
\hline \multirow{3}{*}{ Tratamentos } & \multicolumn{2}{|c|}{ DMV } & \multirow{2}{*}{\multicolumn{2}{|c|}{ DMS }} & \multirow{2}{*}{\multicolumn{2}{|c|}{$\begin{array}{c}\text { Partícula } \\
\text { mm }\end{array}$}} \\
\hline & \multicolumn{2}{|c|}{--o- $\mathrm{kg} \mathrm{m}^{-3}$ - } & & & & \\
\hline & \multicolumn{6}{|c|}{ Verão } \\
\hline T15 & $633^{a}$ & $(14,6)$ & $115^{\mathrm{ab}}$ & $(4,5)$ & $31^{b}$ & $(0,8)$ \\
\hline T30 & $607^{\mathrm{ab}}$ & $(14,6)$ & $118^{\mathrm{a}}$ & $(4,5)$ & $31^{\mathrm{bB}}$ & $(0,8)$ \\
\hline T45 & $569^{\mathrm{bc}}$ & $(14,6)$ & $107^{\mathrm{ab}}$ & $(4,5)$ & $32^{\mathrm{bA}}$ & $(0,8)$ \\
\hline T60 & $530^{\mathrm{cA}}$ & $(14,6)$ & $104^{\mathrm{bB}}$ & $(4,5)$ & $36^{\mathrm{aA}}$ & $(0,8)$ \\
\hline T90 & $542^{\mathrm{cA}}$ & $(14,6)$ & $112^{\mathrm{abB}}$ & $(4,5)$ & $36^{\mathrm{aA}}$ & $(0,8)$ \\
\hline \multirow[t]{2}{*}{ Média } & $576^{\mathrm{A}}$ & $(6,5)$ & $111^{\mathrm{B}}$ & $(2,0)$ & $33^{\mathrm{A}}$ & $(0,3)$ \\
\hline & \multicolumn{6}{|c|}{ Inverno } \\
\hline T15 & $N^{*}$ & ND & ND & ND & ND & ND \\
\hline T30 & ND & ND & ND & ND & $36^{\mathrm{aA}}$ & $(1,6)$ \\
\hline T45 & ND & ND & ND & ND & $33^{\mathrm{abA}}$ & $(1,2)$ \\
\hline T60 & $442^{\mathrm{aB}}$ & $(17,2)$ & $148^{\mathrm{aA}}$ & $(5,3)$ & $31^{\mathrm{bB}}$ & $(0,9)$ \\
\hline T90 & $474^{\mathrm{aB}}$ & $(17,2)$ & $140^{\mathrm{aA}}$ & $(5,3)$ & $34^{\mathrm{aA}}$ & $(0,8)$ \\
\hline Média & $458^{\mathrm{B}}$ & ND & $144^{\mathrm{A}}$ & ND & $34^{\mathrm{A}}$ & ND \\
\hline
\end{tabular}

${ }^{*} \mathrm{ND}$ - não determinado.

Valores entre parênteses indicam o erro padrão da média (EPM).

Médias na coluna seguidas de mesmas letras maiúsculas, nos mesmos tratamentos e em diferentes estações, não diferem entre si $(P>0,05)$.

Médias na coluna seguidas de mesmas letras minúsculas, nas mesmas estações, não diferem entre si $(P>0,05)$.

Conforme mencionado previamente, o tamanho médio das partículas afeta diretamente a densidade da massa de forragem, isso pode ser observado através da Figura 13 que mostra, nesse caso, a medida indireta do tamanho de 
partícula como a porcentagem da massa de forragem que foi retida acima da peneira de orifícios de $38 \mathrm{~mm}$. Observa-se que esse parâmetro apresentou consistente efeito linear negativo sobre a densidade.

$O$ efeito do aumento no intervalo entre cortes alterando a densidade pôde ser verificado nas DMV de verão, as quais demonstram decréscimos na densidade conforme o intervalo entre cortes foi aumentado. Os menores tamanhos médios de partículas nos tratamentos T15, T30 e T45 proporcionaram uma melhor acomodação da massa ensilada, verificada pelas maiores DMV. A maior densidade em T15 de verão pode ser explicada pelo alto teor de umidade na forragem (Tabela 15), que além de condicionar um menor tamanho de partícula (Tabela 22), poderia causar melhor acomodação das mesmas.

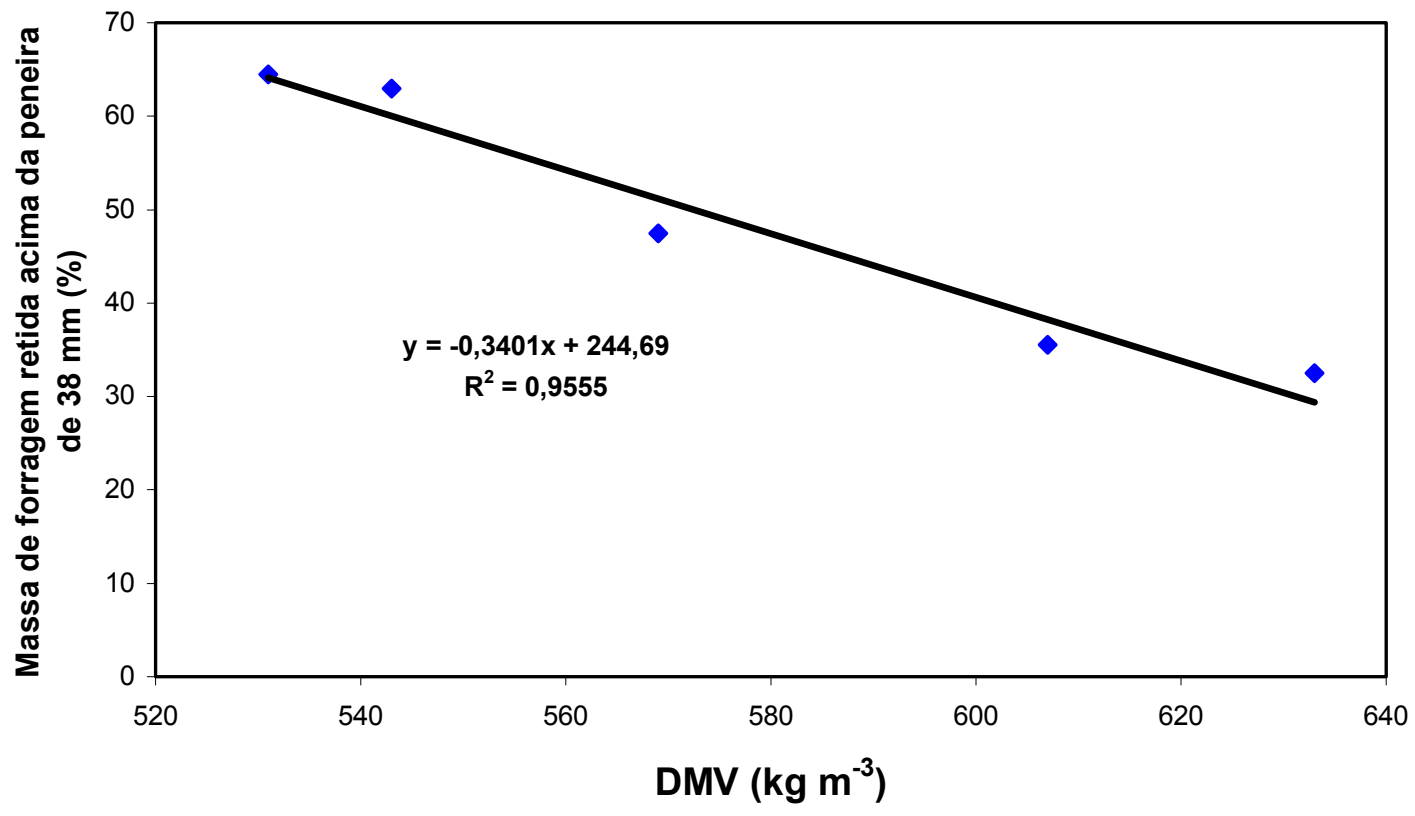

Figura 13 - Representação gráfica do tamanho de partículas (\% retida na peneira de $38 \mathrm{~mm}$ ) em função da densidade da massa verde das silagens de capim-Marandu confeccionadas no verão 
O efeito estacional, revelando uma menor DMV no inverno $\left(458 \mathrm{~kg} \mathrm{~m}^{-3}\right)$, também ocorreu em virtude do alto teor de MS encontrado nas silagens confeccionadas nessa estação. Em silagens de forragens que não sofreram emurchecimento Igarasi (2002) encontrou valores superiores aos do presente trabalho, sendo no verão de $652 \mathrm{~kg} \mathrm{~m}^{-3}$ e no inverno de $491 \mathrm{~kg} \mathrm{~m}^{-3}$. Além da comparação de diferentes espécies (Brachiaria sp. vs. Panicum sp.), deve-se ressaltar que, em decorrência do efeito evidente do teor de umidade da forragem sobre a densidade, é possível que as tendências observadas para estações do ano, sejam de fato, indiretamente associadas ao teor de MS encontrado na forragem colhida.

As DMV das silagens de verão encontradas neste experimento foram semelhantes às relatadas por Narciso Sobrinho et al. (1998b) para as silagens com forragem fresca de capim-elefante $\left(583 \mathrm{~kg} \mathrm{~m}^{-3}\right)$, embora esses autores não tenham verificado efeito do intervalo entre cortes como o encontrado $(P<0,01)$ no presente experimento. Quando comparadas com as densidades alcançadas por Lima et al. (1972) (467 $\left.\mathrm{kg} \mathrm{m}^{-3}\right)$ para capim-elefante, as DMV apresentadas na Tabela 22 mostraram-se mais elevadas.

Com relação à DMS houve efeito da estação do ano $(P<0,01)$, não tendo sido verificado efeito do intervalo entre cortes $(P=0,32)$, da interação intervalo entre cortes $x$ estação do ano $(P=0,13)$ e de bloco $(P=0,63)$. As DMS variaram entre 104 e $148 \mathrm{~kg} \mathrm{~m}^{-3}$, nos tratamentos T60 de verão e T60 de inverno, respectivamente. A DMS média no verão foi de $111 \mathrm{~kg} \mathrm{~m}^{-3}$, em média, e no inverno de $144 \mathrm{~kg} \mathrm{~m}^{-3}$.

Pôde-se observar que em todos os tratamentos, nas duas estações do ano, os valores de DMS foram muito inferiores àqueles preconizados por Holmes \& Muck (1999) como sendo mínimo para a compactação ideal (225 kg $M S \mathrm{~m}^{-3}$ ). Contudo, no presente trabalho, apesar da média ter sido de $127 \mathrm{~kg}$ $\mathrm{m}^{-3}$, a silagem apresentou características sensoriais satisfatórias. Igarasi (2002) também encontrou valores médios de DMS inferiores ao ideal (150 kg MS m${ }^{-3}$ ), 
mas os parâmetros fermentativos, assim como os sensoriais, também foram considerados satisfatórios.

A comparação dos efeitos da análise de variância encontrados entre as duas densidades, DMV e DMS, revela que embora a DMV tenha sido diferente entre as estações, a DMS não apresentou o mesmo padrão. Isso poderia ser justificado pelo alto teor de MS encontrado nos tratamentos de inverno, que associado a menores DMV, revelou, nas médias de DMS, um efeito tipicamente compensatório e, portanto, não apresentando diferenças entre intervalos entre cortes $(P>0,05)$ para essa variável.

\subsubsection{Condutividade elétrica das silagens}

Os resultados referentes à condutividade elétrica das silagens de capimMarandu estão apresentados na Tabela 23. Houve efeito do intervalo entre cortes $(P<0,01)$, da estação do ano $(P<0,01)$ e da interação intervalo entre cortes $x$ estação do ano $(P<0,01)$, não tendo sido verificado efeito de bloco $(P=0,78)$. A amplitude de variação da $C E$ das silagens de capim-Marandu variou de $0,81 \mathrm{mS} \mathrm{cm}^{-1}$ (T60, verão) a $1,37 \mathrm{mS} \mathrm{cm}^{-1}$ (T30, inverno). A CE média na estação de verão foi menor $\left(0,91 \mathrm{mS} \mathrm{cm}^{-1}\right)$ que a encontrada na estação de inverno $\left(1,26 \mathrm{mS} \mathrm{cm}^{-1}\right)$.

Tanto no verão quanto no inverno houve redução no valor da CE conforme aumentou-se o intervalo entre cortes. Ainda foi possível observar que, no verão, isso foi acompanhado do aumento no tamanho médio das partículas (Tabela 22) e da retenção percentual da MS sobre a peneira provida de orifícios de $38 \mathrm{~mm}$ de diâmetro (Figura 14). Através da derivada da equação proposta nessa figura, foi possível concluir que a menor CE seria obtida se $74 \%$ do material fossem retidos na peneira de $38 \mathrm{~mm}$ e tendência similar foi encontrada por Kraus et al. (1997). 


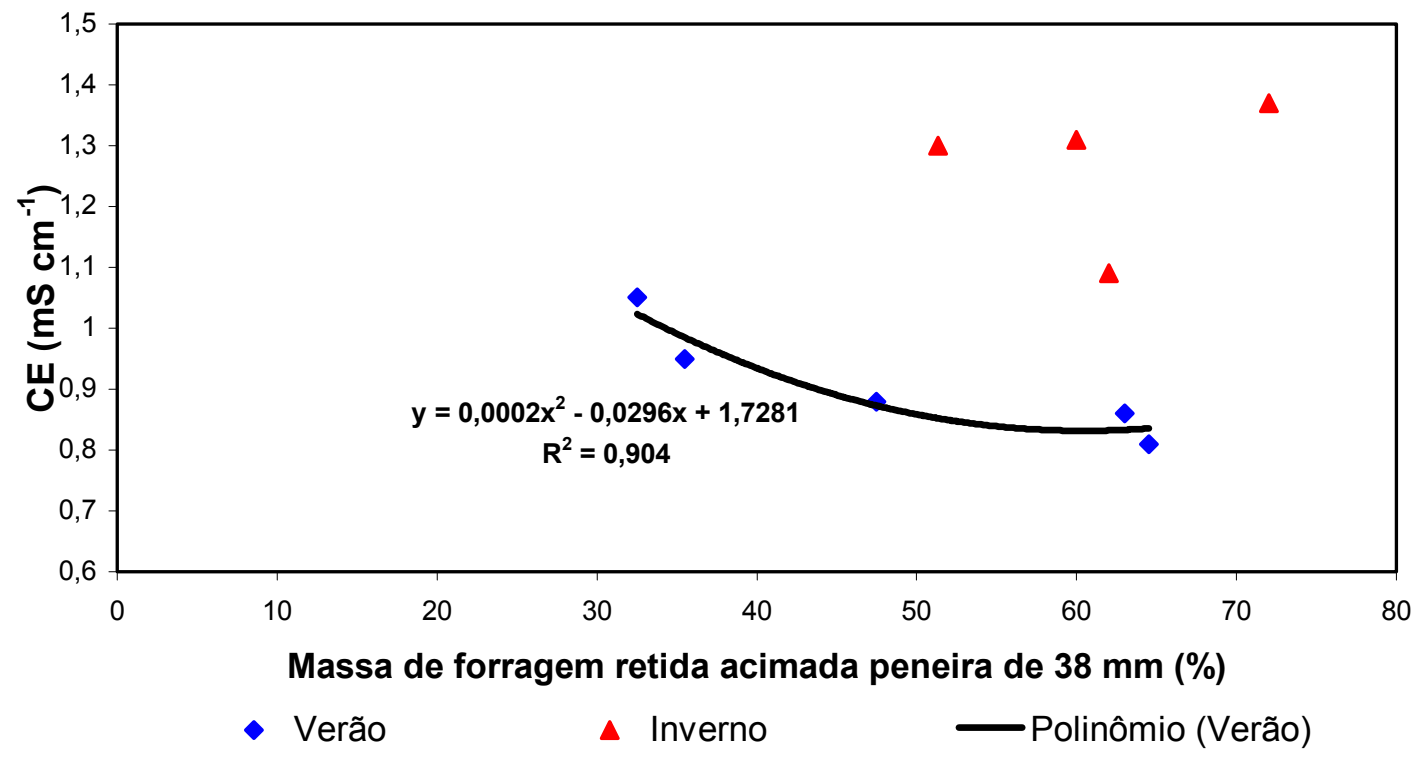

Figura 14 - Representação gráfica da distribuição da condutividade elétrica em função do tamanho de partículas (\% retida na peneira de $38 \mathrm{~mm}$ ) de silagens de capim-Marandu durante o verão e o inverno

Os elevados valores de CE encontrados nos menores intervalos entre cortes, sobretudo no verão, podem ser decorrentes dos elevados teores de CZ observados nesses tratamentos (Tabela 18) e também da maior intensidade de ruptura celular causado pelo processamento físico da forragem, observado pelo menor tamanho médio das partículas em tais tratamentos (Tabela 22), extravasando, assim, maior quantidade de líquido intracelular rico em eletrólitos. Resultado concordante foi relatado por Pauly et al. (1999) que encontraram maiores valores de CE para as silagens com menores tamanhos médios de partícula. 
Tabela 23. Condutividade elétrica e atividade de água das silagens de capimMarandu, submetido a intervalo entre cortes, em duas estações do ano, verão e inverno

\begin{tabular}{llclc}
\hline Tratamentos & \multicolumn{2}{c}{$\mathrm{CE} \mathrm{mS} \mathrm{cm}^{-1}$} & \multicolumn{2}{c}{$\mathrm{Aw}$} \\
\hline & & \multicolumn{3}{c}{ Verão } \\
T15 & $1,05^{\mathrm{a}}$ & $(0,029)$ & $0,840^{\mathrm{b}}$ & $(0,0113)$ \\
T30 & $0,95^{\mathrm{bB}}$ & $(0,029)$ & $0,857^{\mathrm{abA}}$ & $(0,0113)$ \\
T45 & $0,88^{\mathrm{bcB}}$ & $(0,029)$ & $0,884^{\mathrm{aA}}$ & $(0,0113)$ \\
T60 & $0,81^{\mathrm{cB}}$ & $(0,029)$ & $0,865^{\mathrm{abA}}$ & $(0,0113)$ \\
T90 & $0,86^{\mathrm{bCB}}$ & $(0,029)$ & $0,878^{\mathrm{aA}}$ & $(0,0113)$ \\
Média & $0,91^{\mathrm{B}}$ & $(0,013)$ & $0,865^{\mathrm{A}}$ & $(0,5066)$ \\
& & & & \\
T15 & $\mathrm{ND}^{*}$ & $\mathrm{ND}$ & $\mathrm{ND}^{\mathrm{a}}$ & $\mathrm{ND}$ \\
T30 & $1,37^{\mathrm{aA}}$ & $(0,062)$ & $0,878^{\mathrm{aA}}$ & $(0,0237)$ \\
T45 & $1,30^{\mathrm{aA}}$ & $(0,043)$ & $0,858^{\mathrm{aA}}$ & $(0,0166)$ \\
T60 & $1,30^{\mathrm{aA}}$ & $(0,035)$ & $0,865^{\mathrm{aA}}$ & $(0,0133)$ \\
T90 & $1,09^{\mathrm{bA}}$ & $(0,029)$ & $0,860^{\mathrm{aA}}$ & $(0,0113)$ \\
Média & $1,26^{\mathrm{A}}$ & $\mathrm{ND}$ & $0,865^{\mathrm{A}}$ & $\mathrm{ND}$ \\
\hline
\end{tabular}

${ }^{*} \mathrm{ND}$ - não determinado.

Valores entre parênteses indicam o erro padrão da média (EPM).

Médias na coluna seguidas de mesmas letras maiúsculas, nos mesmos tratamentos e em diferentes estações, não diferem entre si $(P>0,05)$.

Médias na coluna seguidas de mesmas letras minúsculas, nas mesmas estações, não diferem entre si $(P>0,05)$.

A diferença entre as estações demonstrou que o maior teor de MS foi associado à maior $\mathrm{CE}$, conforme havia sido observado anteriormente por Balsalobre et al. (2001) e Castro et al. (2001). Contudo, tendência oposta foi observada por Igarasi (2002), em que silagens de capim-Tanzânia confeccionadas no verão, portanto, com baixo teor de MS, apresentaram maior valor de $\mathrm{CE}$ que as de inverno. No presente experimento, entretanto, os 
resultados das silagens de verão não seguem essa tendência, uma vez que os maiores teores de MS (T90) apresentaram menores CE. Esse fato talvez possa ser justificado pela amplitude do teor de MS na qual estejam inseridas essas silagens. É possível que sob menores teores de MS, a CE seja mais suscetível às mudanças químicas ocorridas na composição da forragem, enquanto que, sob maiores teores de MS a alteração da CE seja mais relacionada às rupturas físicas da parede celular, teoria justificada pela análise de Castro et al. (2001) em que a amplitude do teor de MS variou entre $25 \%$ e $65 \%$.

\subsubsection{Atividade de água das silagens}

Os resultados referentes à $A w$ das silagens de capim-Marandu estão apresentados na Tabela 23. Não houve efeito do intervalo entre cortes $(P=0,24)$, nem da estação do ano $(P=0,56)$, também não houve efeito da interação intervalo entre cortes $x$ estação do ano $(P=0,48)$, tampouco de bloco $(P=0,29)$.

Os valores de Aw encontrados para os diferentes intervalos entre cortes não seguiram a tendência dos dados encontrados na literatura (Castro et al., 2001; Leitão, 1997 e McDonald et al., 1991), nos quais os incrementos no conteúdo de MS determinaram decréscimos na Aw. Contudo, os valores observados encontraram-se dentro da amplitude relatada por Castro et al. (2001), entre 0,690 e 0,850, para silagens de Tifton 85 (Cynodon sp.) com teores de MS próximos aos do presente estudo. Entretanto, Igarasi (2002) encontrou valores de Aw superiores a 0,930, tanto para as silagens de capimTanzânia confeccionadas no verão quanto naquelas confeccionadas no inverno.

Embora tenha sido alterado o grau de ruptura celular, observado pelos valores da CE, o tamanho médio das partículas, o teor de MS e a densidade da massa ensilada, não se observou alteração na Aw e isso seria extremamente desejável para uma silagem, uma vez que, sob um menor teor de MS, não foi detectada maior quantidade de água livre disponível a crescimento bacteriano 
indesejável, sobretudo Clostrium sp.. De acordo com Wieringa (1966), esses microrganismos são ávidos por água e sensíveis a aumentos na pressão osmótica. Isso concorda com a teoria proposta por Igarasi (2002) que concluiu que em forragens tropicais é possível observar-se uma maior umidade na silagem sem, contudo, favorecer a fermentação por Clostridium sp..

Utilizando a fórmula proposta por Greenhill (1964), a Aw da forragem é determinada pela Equação 7 .

$$
A w=1-\frac{c}{m}
$$

onde:

Aw = atividade de água da forragem (umidade relativa de pressão de vapor);

$\mathrm{c} \quad=$ constante (determinada pela contribuição das moléculas e íons da forragem);

$\mathrm{m} \quad=$ umidade contida $\left(\mathrm{g} \mathrm{H}_{2} \mathrm{O} \mathrm{g}^{-1}\right.$ de matéria seca) .

Greenhill (1964) calculou a constante (c) para diversas espécies de plantas forrageiras e verificou a influência de diversos fatores, como a maturidade da forragem, por exemplo, e verificou que para azevém os valores ficaram entre 0,02 e 0,04 , enquanto que para trevo e alfafa (Medicago sativa L.) os valores variaram de 0,03 a 0,05. Igarasi (2002), utilizando a mesma fórmula, para silagens de capim-Tanzânia, encontrou valores superiores aos detectados por Greenhill (1964). Os valores da constante c encontrados por Igarasi (2002) variaram entre 0,08 e 0,13, sugerindo que a somatória das cargas iônicas e o peso das moléculas das gramíneas tropicais seriam maiores que em relação às forragens temperadas. Adicionalmente, a maior quantidade de carga iônica e peso das moléculas nas gramíneas tropicais permitiria a essas uma umidade mais elevada sem, contudo, alterar a Aw. O autor sugeriu ainda, que na ensilagem de capins tropicais o teor de MS recomendado pela literatura 
internacional, com base em gramíneas temperadas, talvez estivesse superestimado e sendo assim, silagens de gramíneas tropicais poderiam obter sucesso impedindo fermentação clostrídica sob teores de MS mais reduzidos.

Com a aplicação da fórmula de Greenhill (1964) para os resultados do presente trabalho foram encontradas variações de 0,03 a 0,11 na constante $c$. Os valores dessa constante no verão situaram-se, parcialmente, dentro da faixa proposta por Greenhill (1964) quando avaliou azevém.

\subsubsection{Produção de efluente das silagens}

Os resultados referentes à produção de efluente das silagens de capimMarandu estão apresentados na Tabela 24. Houve efeito da estação do ano $(P<0,01)$, não tendo sido verificado efeito do intervalo entre cortes $(P=0,18)$, da interação intervalo entre cortes $x$ estação do ano $(P=0,54)$ e de bloco $(P=0,13)$. A amplitude das produções de efluente das silagens variou de $47,7 \mathrm{~kg} \mathrm{t}^{-1}$ de massa verde (MV) (T90 no verão) a zero (inverno) e por conseqüência dessa diferença foi verificado o efeito das estações que tiveram médias de $37,6 \mathrm{~kg} \mathrm{t}^{-1}$ $M V$ e $0,2 \mathrm{~kg} \mathrm{t}^{-1}$ de $\mathrm{MV}$, nos tratamentos de verão e inverno, respectivamente.

Há dificuldade de comparação das produções de efluente na literatura em virtude das diferentes unidades utilizadas, como litros de efluente por tonelada de material ensilado (Alli et al., 1985; Bernardes, 2003; Fransen \& Strubi, 1998; Haigh, 1999; Jones et al., 1990; Jones \& Jones, 1995 e Reynolds \& Wiliams, 1995) e kg de efluente por tonelada de material ensilado (Igarasi, 2002; Keady \& O'Kiely, 1996 e O'Donnell et al., 1997). Além da dificuldade de padronização da unidade experimental, segundo Balsalobre et al. (2001) e Jones \& Jones (1995), outros fatores devem ser considerados na avaliação de perdas por efluentes como tipo e dimensão do silo, pressão de compactação e aplicação de aditivos, no entanto, o teor de MS, segundo McDonald et al. (1991), é o mais importante. 
Assim como Haigh (1999), Igarasi (2002) encontrou equação exponencial para a produção de efluente em função do teor de $\mathrm{MS}$, de acordo com a Equação 8:

Efluente $=650,47 \mathrm{e}^{-0,1415 . \mathrm{MS}}$

onde:

MS = teor de matéria seca (\%).

No presente trabalho a equação que melhor se adaptou da produção de efluente em função do teor de $M S$ foi linear, com $R^{2}=0,88$, como pode ser verificado pela Figura 15. Através dela foi observado que aos 32,5\% de MS não ocorreria mais produção de efluentes. Para Haigh (1999), o teor de MS limiar para evitar o aparecimento de efluente seria de $25,4 \%$, enquanto que para Bernardes (2003) teores de MS superiores a $30,2 \%$, em silagem de capimMarandu adicionada de $10 \%$ de polpa cítrica peletizada, não foram suficientes para eliminar a produção de efluente. No experimento de Igarasi (2002), a estimativa do limiar para eliminação da ocorrência de efluente seria superior a $45 \%$ de MS.

Um comportamento atípico ocorreu no corte para ensilagem do capimMarandu durante o verão, no qual à medida que o intervalo entre cortes se distanciou e, conseqüentemente, houve aumento no teor de MS da silagem verificou-se incremento na produção de efluentes. Até mesmo o menor tamanho das partículas encontrado nos tratamentos com intervalos entre cortes menores mostrou menor produção de efluente que em cortes resultantes de intervalos mais distanciados.

No presente trabalho as produções de efluente encontradas no verão foram semelhantes às de Igarasi (2002), para as silagens de capim-Tanzânia, também confeccionadas no verão e que utilizaram forragem com umidade original. Entretanto, Igarasi (2002) continuou observando a ocorrência de 
efluentes (11 $\mathrm{kg} \mathrm{t}^{-1} \mathrm{MV}$ ), mesmo em silagens de inverno, com elevado teor de MS, decorrentes, tanto do emurchecimento como da adição de polpa cítrica peletizada. No presente estudo, as silagens de inverno não apresentaram produção de efluentes.

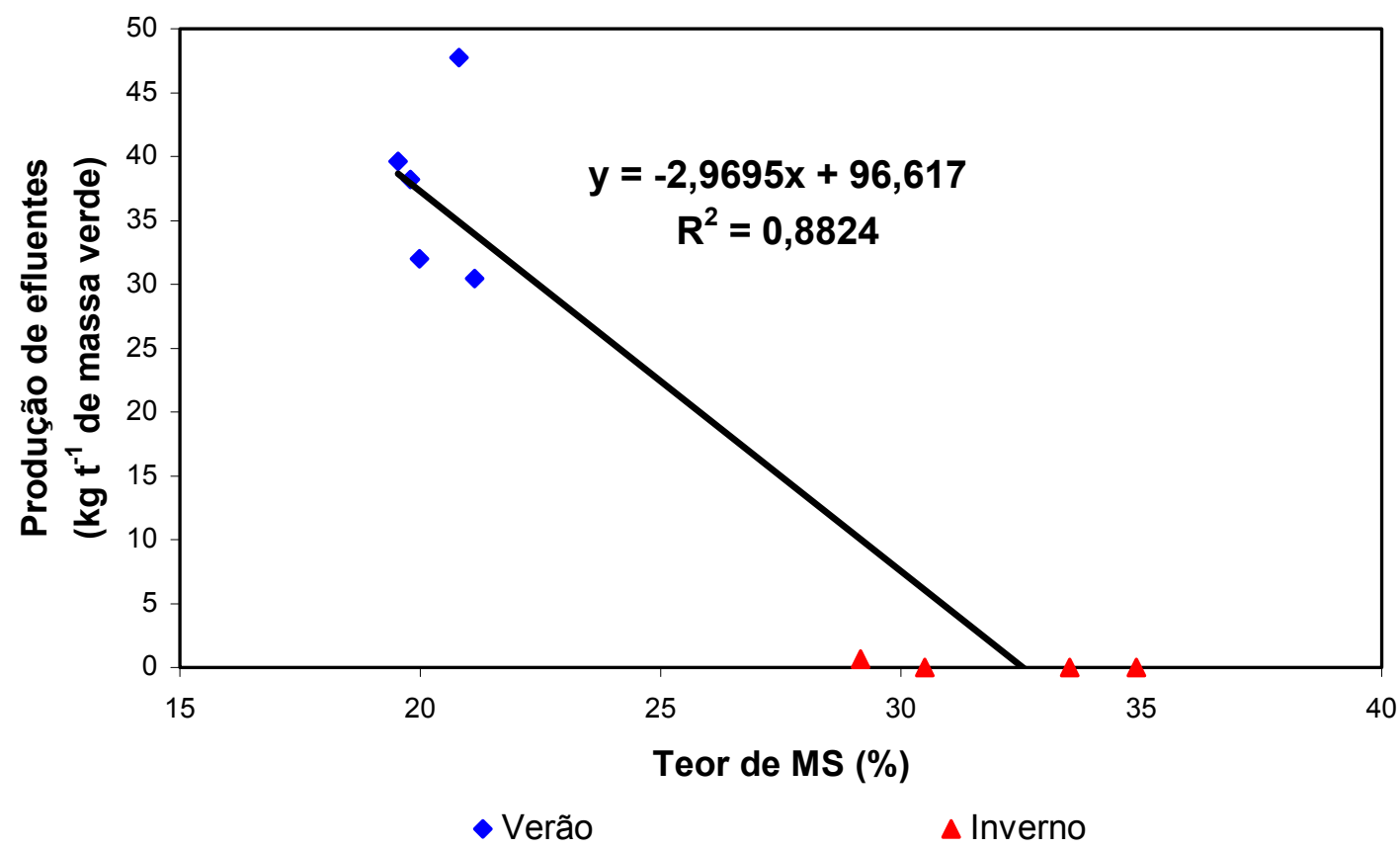

Figura 15 - Representação gráfica da produção de efluente em função do teor de matéria seca das silagens de capim-Marandu confeccionadas no verão e no inverno

Loures (2000) verificou que 55\% do efluente produzido durante a ensilagem ocorreu nos dois primeiros dias após o fechamento dos silos. Citou ainda, que a produção de efluente variou de acordo com o grau de compactação (pressão) empregado, indicando, assim, que outros fatores interferem na produção de efluente como grau de compactação e a densidade da massa ensilada. Ainda a ruptura celular e, como efeito dessa, o extravasamento de íons, pode ter exercido influência na resposta da produção 
de efluentes. Entretanto, a teoria apresentada por Loures (2000) não está de acordo com os resultados apresentados nas Tabelas 22 e 23.

\subsubsection{Perdas por gases das silagens}

Os resultados referentes à produção de gases das silagens de capimMarandu estão apresentados na Tabela 24. Houve efeito do intervalo entre cortes $(P<0,01)$ e da estação do ano $(P<0,01)$, não tendo sido verificado efeito da interação intervalo entre cortes $x$ estação do ano $(P=0,25)$ e de bloco $(\mathrm{P}=0,81)$. A produção de gases decorrente do processo fermentativo variou de 2,3\% (T90 de verão) a 7,6\% (T90 de inverno). O valor médio de produção de gases foi maior no inverno $(7,2 \%)$ que no verão $(4,7 \%)$.

No desdobramento dos tratamentos dentro das estações do ano notouse que, no verão, com exceção do T30 que apresentou produção de gases intermediária, houve tendência de decréscimo na produção de gases com o aumento do intervalo entre cortes. Isso provavelmente deve ter ocorrido em virtude da maior ruptura da parede celular (Tabela 23) e escoamento de seu conteúdo nos tratamentos de menor intervalo entre cortes onde a possibilidade de fermentação clostrídica tenha sido maior. A mesma tendência foi verificada por Igarasi (2002) quando a silagem estudada apresentou alto teor de umidade $(15,6 \%)$. Na ensilagem de inverno, não foi encontrada diferença na produção de gases com o aumento no intervalo entre cortes.

Nos dois tratamentos possíveis de serem comparados entre as estações, T60 e T90, notou-se que nos tratamentos de inverno a produção de gases foi maior que no verão e isso poderia ser justificado pela dificuldade de acomodação da massa ensilada, traduzida em menor DMV (Tabela 22) e maior tamanho médio das partículas. Aguiar et al. (2001) também comprovou essa tendência, com diminuição da produção de gases com o menor tamanho de partículas. O decréscimo na DMV levou ao aquecimento da massa ensilada com conseqüente aumento na produção de gases. 
Tabela 24. Produção de efluente, perdas por gases e recuperação de matéria seca das silagens de capim-Marandu, submetido a intervalo entre cortes, em duas estações do ano, verão e inverno

\begin{tabular}{llccccc}
\hline \multirow{2}{*}{ Tratamentos } & \multicolumn{2}{c}{ Efluente } & \multicolumn{2}{c}{ Gases } & \multicolumn{2}{c}{ Recuperação MS } \\
& \multicolumn{2}{c}{$\mathrm{kg} \mathrm{t}^{-1} \mathrm{MV}$} & \multicolumn{2}{c}{$\% \mathrm{MS}$} \\
\hline & & \multicolumn{2}{c}{ Verão } \\
T15 & $32,0^{\mathrm{b}}$ & $(3,80)$ & $6,7^{\mathrm{a}}$ & $(0,73)$ & $87,5^{\mathrm{b}}$ & $(1,87)$ \\
T30 & $30,4^{\mathrm{bA}}$ & $(3,80)$ & $4,4^{\mathrm{b}}$ & $(0,73)$ & $89,0^{\mathrm{b}}$ & $(1,87)$ \\
T45 & $38,1^{\mathrm{abA}}$ & $(3,80)$ & $6,7^{\mathrm{a}}$ & $(0,73)$ & $91,3^{\mathrm{ab}}$ & $(1,87)$ \\
T60 & $39,6^{\mathrm{abA}}$ & $(3,80)$ & $3,3^{\mathrm{cB}}$ & $(0,73)$ & $95,4^{\mathrm{aA}}$ & $(1,87)$ \\
T90 & $47,7^{\mathrm{aA}}$ & $(3,80)$ & $2,3^{\mathrm{cB}}$ & $(0,73)$ & $95,1^{\mathrm{aA}}$ & $(1,87)$ \\
Média & $37,6^{\mathrm{A}}$ & $(1,70)$ & $4,7^{\mathrm{B}}$ & $(0,32)$ & $91,7^{\mathrm{A}}$ & $(0,84)$ \\
& & & \multicolumn{2}{c}{ Inverno } & & \\
T15 & $\mathrm{ND}$ & $\mathrm{ND}$ & $\mathrm{ND}$ & $\mathrm{ND}$ & $\mathrm{ND}$ & $\mathrm{ND}$ \\
T30 & $0^{\mathrm{aB}}$ & $\mathrm{ND}$ & $\mathrm{ND}$ & $\mathrm{ND}$ & $\mathrm{ND}$ & $\mathrm{ND}$ \\
T45 & $0^{\mathrm{aB}}$ & $\mathrm{ND}$ & $\mathrm{ND}$ & $\mathrm{ND}$ & $\mathrm{ND}$ & $\mathrm{ND}$ \\
T60 & $0^{\mathrm{aB}}$ & $\mathrm{ND}$ & $6,8^{\mathrm{aA}}$ & $(0,86)$ & $97,7^{\mathrm{aA}}$ & $(2,21)$ \\
T90 & $0,6^{\mathrm{aB}}$ & $(3,80)$ & $7,6^{\mathrm{aA}}$ & $(0,73)$ & $96,7^{\mathrm{aA}}$ & $(1,87)$ \\
Média & $0,2^{\mathrm{B}}$ & $\mathrm{ND}$ & $7,2^{\mathrm{A}}$ & $\mathrm{ND}$ & $97,2^{\mathrm{A}}$ & $\mathrm{ND}$ \\
\hline
\end{tabular}

${ }^{*} \mathrm{ND}$ - não determinado.

Valores entre parênteses indicam o erro padrão da média (EPM).

Médias na coluna seguidas de mesmas letras maiúsculas, nos mesmos tratamentos e em diferentes estações, não diferem entre si $(P>0,05)$.

Médias na coluna seguidas de mesmas letras minúsculas, nas mesmas estações, não diferem entre si $(P>0,05)$.

Com relação à diferença encontrada entre as estações, esta reflete, principalmente, a intensidade de estabelecimento do ambiente anaeróbico, pois nas silagens confeccionadas durante o inverno a dificuldade de acomodação pode ter levado a fermentações indesejáveis que elevaram as perdas por gases. Entretanto, nas silagens de verão o ambiente anaeróbico foi estabelecido mais rapidamente em função da elevada densidade (Tabela 22) e 
baixo teor de MS (Tabela 18), gerando menores perdas por gases. Contudo esse raciocínio é contrastante com a maior possibilidade de desenvolvimento de Clostridium sp., nessas silagens úmidas, que de forma oposta, induziria a maior produção de gases. Com isso, é provável que os dados erráticos relativos à produção de gases em silagens de gramíneas tropicais com umidade elevada sejam decorrentes da ponderação entre os efeitos negativos da atividade de Clostridium sp. e dos benefícios relacionados com a compactação mais eficiente.

\subsubsection{Taxa de recuperação de matéria seca das silagens}

Os resultados referentes à taxa de recuperação de matéria seca das silagens de capim-Marandu estão apresentados na Tabela 24. Houve efeito do intervalo entre cortes $(P<0,05)$, não tendo sido verificado efeito da estação do ano $(P=0,34)$, da interação intervalo entre cortes $x$ estação do ano $(P=0,86)$ e de bloco $(P=0,62)$. A amplitude observada para a taxa de recuperação da MS variou de $87,5 \%$ (T15, verão) a $97,7 \%$ (T60, inverno).

A análise dos tratamentos dentro das estações do ano demonstrou que houve tendência, no verão, de maiores taxas de recuperação da MS com o maior espaçamento dos cortes. Embora tenham sido observadas maiores perdas por efluente nos tratamentos resultantes de maiores intervalos entre cortes, a quantidade de efluente produzido pode ser considerada pouco expressiva. No entanto, a taxa de recuperação foi maior em virtude do maior teor de MS desses tratamentos, sugerindo que a taxa de recuperação de MS seja mais intensamente prejudicada pelo aumento na produção de gases, conforme pode ser observado na Tabela 24. 


\subsection{Conclusões}

A ensilagem de capim-Marandu produzida durante o inverno, nas condições propostas de manejo intensivo, se constituiu em boa opção de volumoso suplementar.

As medidas físicas utilizadas podem mostrar consistência satisfatória na interação com o valor nutritivo de silagens de capim-Marandu, sendo sugerida a adoção dessas na condução de futuros estudos.

A análise integrada dos resultados sugere não haver possibilidade de se conciliar ótimas condições de fermentação simultâneas ao máximo valor nutritivo da forragem. Dessa forma, a definição de uma estratégia de utilização de capim-Marandu para a produção de silagem deverá atender objetivos específicos do sistema de produção onde estiver inserido. 


\section{CONCLUSÕES GERAIS}

A otimização da produção de MS digestível, que reflete a ponderação entre a variação na produção de MS e no valor nutritivo, ocorreu em forragens colhidas aos 60 dias de crescimento vegetativo, coincidindo com menores perdas associadas ao processo fermentativo de suas silagens.

As comparações efetuadas entre estações do ano refletem, de fato, alterações de composição condicionadas pelas variáveis ambientais presentes nas estações. Assim, a consideração das variações ambientais e sua correlação com os padrões de crescimento da forragem parecem ser mais adequadas ao descrever ou predizer a composição morfológica ou químicobromatológica da forragem.

A ensilagem de capim-Marandu produzida durante o inverno, nas condições propostas de manejo intensivo, se constituiu em boa opção de volumoso suplementar.

A análise integrada dos resultados sugere não haver possibilidade de se conciliar ótimas condições de fermentação simultâneas ao máximo valor nutritivo da forragem. Dessa forma, a definição de uma estratégia de utilização de capim-Marandu para a produção de silagem deverá atender objetivos específicos do sistema de produção onde estiver inserido. 


\section{REFERÊNCIAS BIBLIOGRÁFICAS}

ACUNHA, J.B.V.; COELHO, R.W. Efeito da altura e intervalo de corte do capim-elefante-anão. I. Produção e qualidade da forragem. Pesquisa Agropecuária Brasileira, v.32, n.1, p.117-122, 1997.

AGUIAR, R.N.S.; CRESTANA, R.F.; NUSSIO, L.G. et al. Efeito do tamanho de partícula na composição da fração nitrogenada de silagens de capim Tanzânia. In: REUNIÃO ANUAL DA SOCIEDADE BRASILEIRA DE ZOOTECNIA, 38., Piracicaba. Anais. Piracicaba: FEALQ, 2001. p.314315.

ALCÂNTARA, V.B.G.; PEDREIRA, J.V.S.; MATTOS, H.B. et al. Medidas in vitro de valores nutritivos de capins. I - Produção e digestibilidade in vitro de vinte e cinco capins durante o outono e inverno. Boletim da Indústria Animal, v.38, n.2, p.155-176, 1981.

ALLI, I.; THIFFAULT, C.; BAKER, B.E. A device for monitoring silage effluent produced in laboratory silos. Journal of Dairy Science, v.68, p.3355-3359, 1985.

ALVIM, M.J.; XAVIER, D.F.; VERNEQUE, R.S. et al. Resposta do Tifton 85 a doses de nitrogênio e intervalo de cortes. Pesquisa Agropecuária Brasileira, v.34, n.12, p.2345-2352, 1999. 
ANDRADE, I.F.; GOMIDE, J.A. Curva de crescimento e valor nutritivo de capim-elefante (Pennisetum purpureum Schum.) "A-146 Taiwan". Revista Ceres, v.18, n.100, p.431-447, 1971.

ANDRADE, J.B.; FERRARI JÚNIOR, E.; PEDREIRA, J.V.S. et al. Produção e qualidade dos fenos de Brachiaria decumbens e Brachiaria brizantha cv. Marandu sob três freqüências de corte. II - Qualidade do feno. Boletim da Indústria Animal, v.51, n.1, p.55-59, 1994.

ASSOCIATION OF OFFICIAL AGRICULTURAL CHEMISTS. Official methods of analysis. 13.ed. Washington, 1980. 1015p.

BALSALOBRE, M.A.A.; NUSSIO, L.G.; MARTHA JÚNIOR, G.B. Controle de perdas na produção de silagens de gramíneas tropicais. In: MATTOS, W.R.S.; FARIA, V.P.; DA SILVA, S.C. et al. (Ed.). A produção animal na visão dos brasileiros. Piracicaba: FEALQ, 2001. p.890-911.

BERNARDES, T.F. Características fermentativas, microbiológicas e químicas do capim-Marandu (Brachiaria brizantha (Hochst ex. A. Rich) Stapf. cv. Marandu) ensilado com polpa cítrica peletizada. Jaboticabal, 2003. 108p. Dissertação (Mestrado) - Faculdade de Ciências Agrárias e Veterinárias, Universidade Estadual Paulista "Julio de Mesquita Filho".

BERZAGHI, P.; COZZI, G.; ANDRIGHETTO, I. The use of near infrared analysis for in situ studies. Journal of Dairy Science, v.80, p.3263-3270, 1997.

BOGDAN, A.V. Tropical pasture and fodder plants. London: Longman, 1977. $475 p$. 
BORGES, A.L.C.C.; RABELO, L.S.; GONÇALVES, L.C. et al. Avaliação da Brachiaria brizantha, cv., Marandu em oito idades de corte em Igarapé MG. Teores de matéria seca, produção de matéria seca e relação folha/haste (compact disc). In: REUNIÃO ANUAL DA SOCIEDADE BRASILEIRA DE ZOOTECNIA, 39., Recife, 2002. Anais. Recife: SBZ, 2002.

BOTREL, M.A.; NOVAES, L.P.N.; ALVIN, M.J. Características forrageiras de algumas gramíneas tropicais. Juiz de Fora: EMBRAPA, CNPGL, 1998. $35 p$.

BRITO, C.J.F.A.; RODELLA, R.A.; DESCHAMPS, F.C. Composição química e bromatológica de Brachiaria brizantha e Brachiaria decumbens. In: REUNIÃO ANUAL DA SOCIEDADE BRASILEIRA DE ZOOTECNIA, 38., Piracicaba. Anais. Piracicaba: FEALQ, 2001. p.150-152.

BROWN, R.H.; BLASER, R.E. Relationships between reserve carbohydrate accumulation and growth rate in orchard grass and tall fescue. Crop Science, v.5, n.6, p.577-581, 1965.

BURTON, G.W.; JACKSON, J.E.; HART, R.H. Effects of cutting frequency and nitrogen on yield, in vitro digestibility, and protein, fiber, and carotene of coastal Bermuda grass (Cynodon dactylon L.). Agronomy Journal, v.50, p.500-502, 1963.

BUXTON, D.R.; FALES, S.L. Plant environment and quality. In: FAHEY JUNIOR, G.C.; COLLINS, M.; MERTENS, D.R. et al. (Ed.). Forage quality, evaluation and utilization. Madison: ASA; SSSA, 1994. p.155-159. 
CAMARÃO, A.P.; BATISTA, H.A.M.; LOURENÇO JÚNIOR, J.B. et al. Composição botânica e valor nutritivo da forragem disponível e dieta selecionada por bubalinos em pastagens de Brachiaria humidicola. Pesquisa Agropecuária Brasileira, v.29, n.3, p.491-501, 1994.

CASTRO, F.G.F. Efeito da idade de corte sobre a produção, composição químico-bromatológica, digestibilidade in vitro da matéria seca e da matéria orgânica e conteúdo de ácido cianídrico de Cynodon nlemfuensis Vanderyst var. Nlemfuensis cv. Florico. Piracicaba, 1997. 128p. Dissertação (Mestrado) - Escola Superior de Agricultura "Luiz de Queiroz", Universidade de São Paulo.

CASTRO, F.G.F.; NUSSIO, L.G.; SIMAS, J.M.C. et al. Parâmetros físicoquímicos da silagem de Tifton 85 (Cynodon sp.) sob efeito de préemurchecimento e de inoculante bacteriano-enzimático. In: REUNIÃO ANUAL DA SOCIEDADE BRASILEIRA DE ZOOTECNIA, 38., Piracicaba. Anais. Piracicaba: FEALQ, 2001. p.270-272.

CECATO, U. Influência da freqüência de corte, de níveis e formas de aplicação do nitrogênio sobre a produção, a composição bromatológica e algumas características da rebrota de capim-aruanã (Panicum maximum Jacq. cv. Aruanã). Jaboticabal, 1993. 112p. Tese (Doutorado) - Faculdade de Ciências Agrárias e Veterinárias de Jaboticabal, Universidade Estadual Paulista "Júlio de Mesquita Filho".

COAN, R.M.; VIEIRA, P.F.; SILVEIRA, R.N. et al. Efeitos do inoculante enzimático-bacteriano sobre a composição química, digestibilidade e qualidade das silagens dos capins Tanzânia e Mombaça. In: REUNIÃO ANUAL DA SOCIEDADE BRASILEIRA DE ZOOTECNIA, 38., Piracicaba, 2001. Anais. Piracicaba: FEALQ, 2001. p.124-126. 
CORSI, M. Produção e qualidade de forragens tropicais. In: Pastagens. Piracicaba: FEALQ, 1990. p.69-85.

CORSI, M.; SANTOS, P.M. Potencial de produção do Panicum maximum. In: SIMPÓSIO SOBRE MANEJO DA PASTAGEM, 12., Piracicaba, 1995. Anais. Piracicaba: FEALQ, 1995. p.275-303.

CORSI, M.; BALSALOBRE, M.A.; SANTOS, P.M. et al. Bases para o estabelecimento do manejo de pastagens de braquiária. In: SIMPÓSIO SOBRE MANEJO DA PASTAGEM, 11., Piracicaba, 1994. Anais. Piracicaba: FEALQ, 1994. p.249-266.

COSTA, N.L. Curva de crescimento e composição química de Brachiaria brizantha cv. Marandu em Rondônia. In: REUNIÃO ANUAL DA SOCIEDADE BRASILEIRA DE ZOOTECNIA, 32., Brasília, 1995. Anais. Brasília: SBZ, 1995. p.38-40.

COSTA, C.; FAVORETTO, V.; MALHEIROS, E.B. Variação na estrutura da vegetação de duas cultivares de Panicum maximum Jacq. (Colonião e Tobiatã) submetidas a diferentes tipos de manejo. Composição em proteína bruta e digestibilidade "in vitro" da matéria seca. Pesquisa Agropecuária Brasileira, v.27, n.12, p.1659-1670, 1992.

COZZOLINO, D.; ACOSTA, Y.; GARCIA, J. Application of near infrared reflectance spectroscopy (NIRS) to forage evaluation in Uruguay. In: INTERNATIONAL GRASSLANDS CONGRESS, 19., São Pedro, 2001. Proceedings. Piracicaba: FEALQ, 2001. p.370. 
CRESTANA, R.F.; AGUIAR, R.N.S.: NUSSIO, L.G. et al. Avaliação das perdas de silagem de capim Tanzânia (Panicum maximum Jacq. Cv. Tanzânia) pré-secado ou com adição de polpa cítrica em três tamanhos de partícula (compact disc). In: SIMPÓSIO INTERNACIONAL DE INICIAÇÃO CIENTÍFICA DA UNIVERSIDADE DE SÃO PAULO, 8., Piracicaba, 2000. Anais. Piracicaba: USP, 2000. (CD-ROM)

CRESTANA, R.F.; AGUIAR, R.N.S.; BALSALOBRE, M.A.A. et al. Efeito da fermentação na fração fibra de silagens de capim Tanzânia. In: REUNIÃO ANUAL DA SOCIEDADE BRASILEIRA DE ZOOTECNIA, 38., Piracicaba. Anais. Piracicaba: FEALQ, 2001. p.354-355.

CRONQUIST, A. The evolution and classification of flowering plants. New York: New York Botanical Gardens, 1988. 555p.

DAVIS, C.E.; JOLLEY, V.D.; MOOSO, G.D. et al. Quality of stockpiled bigalta limpograss forage at varying fertility levels. Agronomy Journal, v.79, n.2, p.229-235, 1987.

DA SILVA, S.C. Manejo de plantas forrageiras dos gêneros Brachiaria, Cynodon e Setaria. In: PEIXOTO, A.M.; MOURA, J.C.; FARIA, V.P. (Ed). Volumosos para bovinos. 2.ed. Piracicaba: FEALQ, 1995. p.29-57.

DRUDI, A.; FAVORETTO, V. Influência da freqüência, época e altura do corte na produção e na composição química do capim-andropógon. Pesquisa Agropecuária Brasileira, v.22, n.11/12, p.1287-1292, 1987. 
EL-MEMARI NETO, A.C.; ZEOULA, L.M.; CECATO, U. et al. Avaliação produtiva e química da Brachiaria brizantha no inverno e primavera (compact disc). In: REUNIÃO ANUAL DA SOCIEDADE BRASILEIRA DE ZOOTECNIA, 39., Recife, 2002. Anais. Recife: SBZ, 2002.

EMPRESA BRASILEIRA DE PESQUISA AGROPECUÁRIA. Sistema brasileiro de classificação de solos. Brasília, 1999. 412p.

ESCOLA SUPERIOR DE AGRICULTURA "LUIZ DE QUEIROZ". Departamento de Ciências Exatas. http://ce.esalq.usp.br/dce/anos.htm (21 ago. 2002).

EUCLIDES, V.P.B.; VALLE, C.B.; SILVA, J.M. et al. Avaliação de forrageiras tropicais manejadas para produção de feno-em-pé. Pesquisa Agropecuária Brasileira, v.25, n.1, p.63-68, 1990.

EUCLIDES, V.P.B.; MACEDO, M.C.M.; VALLE, L.C.S. et al. Avaliação de acessos de Panicum maximum sob pastejo. Campo Grande: EMBRAPA, CNPGC, 1995. 7p.

FERRARI JÚNIOR, E.; ANDRADE, J.B.; PEDREIRA, J.V.S. et al. Produção de feno de Brachiaria decumbens e Brachiaria brizantha cv. Marandu sob três freqüências de corte. I - Produção de matéria seca. Boletim da Indústria Animal, v.51, n.1, p.49-54, 1994.

FAO. http://www.apps.fao.org/PAGE/COLLECTIONS/SUBSET/AGRICULTURE (06 abr. 2003).

FIANU, F.K.; WINGH, J.E. Accumulation and quality of dry matter of giant star, buffel and pangola grasses and their regrowth production. Tropical Agriculture, v.61, n.1, p.63-68, 1984. 
FORMOSO, F.A. Crescimento e produtividade de Andropogon gayanus Kunth, Hyparrenia rufa (Nees) Stapf. e Setaria anceps (Schumm.) Stapf. \& Hub cultivados sob dois espaçamentos e submetidos a dois intervalos de corte. Viçosa, 1987. 62p. Dissertação (Mestrado) - Universidade Federal de Viçosa.

FRANSEN, S.C.; STRUBI, F.J. Relationship among absorbents and the reduction of grass silage effluent and silage quality. Journal of Dairy Science, v.81, p.2633-2644, 1998.

GALE, G.E.; KNIGHT, A.C. Apparatus and procedure for the accurate assessment of forage chop length. In: CONFERENCE ON FORAGE CONSERVATION IN THE 80's, London, 1979. Proceedings. London: British Grassland Society, 1979. p.335-338.

GARCIA, R.; SILVA, U.R. Produtividade e características morfológicas do capim-Buffel (Cenchrus ciliares L.) cv. Gayndah. Revista de Sociedade Brasileira de Zootecnia, v.9, n.2, p.329-342, 1980.

GERDES, L.; WERNER, J.C.; COLOZZA, M.T. et al. Avaliação de características agronômicas e morfológicas das gramíneas forrageiras Marandu, Setária e Tanzânia aos 35 dias de crescimento nas estações do ano. Revista Brasileira de Zootecnia, v.29, n.4, p.947-954, 2000a.

GERDES, L.; WERNER, J.C.; COLOZZA, M.T. et al. Avaliação de características de valor nutritivo das gramíneas forrageiras Marandu, Setária e Tanzânia nas estações do ano. Revista Brasileira de Zootecnia, v.29, n.4, p.955-963, 2000b. 
GOMIDE, J.A. Composição mineral de gramíneas e leguminosas forrageiras tropicais. In: SIMPÓSIO LATINO-AMERICANO SOBRE PESQUISA EM NUTRIÇÃO MINERAL DE RUMINANTES E PASTAGENS, 1., Belo Horizonte, 1976. Anais. Belo Horizonte: EPAMIG, 1976. p.20-33.

GOMIDE, J.A.; NOLLER, C.H.; MOTT, G.O. et al. Effects of plant age and nitrogen fertilization on the chemical composition and in vitro cellulose digestibility of tropical grass. Agronomy Journal, v.61, p.116-119, 1969.

GOMIDE, J.A.; OBEID, J.A.; QUEIROZ, D.S. et al. Freqüência de cortes, espaçamento entre fileiras e adubação de capim-colonião (Panicum maximum Jacques) e capim-jaraguá (Hyparrhenia rufa, (Nees) Stapf.). Revista da Sociedade Brasileira de Zootecnia, v.14, n.3, p.326-337, 1985.

GREENHILL, W.L. Plant juice in relation to silage fermentation. Journal of the British Grassland Society, v.19, p.336-339, 1964.

GRIEVE, C.M.; OSBOURN, D.F. The nutritional value of some tropical grasses. The Journal of Agricultural Science, v.65, n.3, p.411-417, 1965.

HAAG, H.P. Nutrição mineral de forrageiras no Brasil. Campinas: Fundação Cargill, 1984. 152p.

HAGGAR, R.J. Seasonal production of Andropogon gayanus. I. Seasonal changes in yield components and chemical composition. Journal of Agricultural Science, v.74, n.3, p.487-494, 1970. 
HAIGH, P.M. Effluent production from grass silages treated with additives and made in large-scale bunker silos. Grass and Forage Science, v.54, p.208218, 1999.

HARRIS, W. Defoliation as a determinant of the regrowth, persistence and composition of pasture. In: WILSON, J.R. (Ed.). Plant relations in pasture. Melbourne: CSIRO, 1978. p.67-85.

HASSAN, W.E.W.; PHIPPS, R.H.; OWEN, E. Dry matter yield and nutritive value of improved pastures species in Malaysia. Tropical Agriculture, v.64, n.4, p.303-308, 1990.

HOLDEN, L.A. Comparison of methods of in vitro dry matter digestibility for ten feeds. Journal of Dairy Science, v.82, n.8, p.1791-1794, 1999.

HOLMES, B.J.; MUCK, R.E. Factors affecting bunker silos densities. Madison: University of Wisconsin, 1999. 7p.

HOVELAND, C.S.; MONSON, W.G. Genetic and environmental effects on forage quality. In: HOVELAND, C.S. (Ed.). Crop quality, storage and utilization. Madison: ASAE; CSSA; SSSA, 1994. p.450-493.

IGARASI, M.S. Controle de perdas na ensilagem de capim Tanzânia (Panicum maximum Jacq. cv. Tanzânia) sob os efeitos do teor de matéria seca, do tamanho de partícula, da estação do ano e da presença do inoculante bacteriano. Piracicaba, 2002. 152p. Dissertação (Mestrado) - Escola Superior de Agricultura "Luiz de Queiroz", Universidade de São Paulo. 
JONES, D.I.H.; JONES, R.; MOSELEY, G. Effect of incorporating rolled barley in autumn cut ryegrass silage on effluent production, silage fermentation and cattle performance. Journal of Agricultural Science, v.115, p.399-408, 1990.

JONES, D.I.H.; JONES, R. The effect of crop characteristics and ensiling methodology on grass silage effluent production. Journal of Agricultural Engineering Research, v.60, p.73-81, 1995.

KEADY, T.W.; O'KIELY, P. An evaluation of the effects of rate of nitrogen fertilization of the grassland on silage fermentation, in silo losses, effluent production and stability. Grass and forage Science, v.51, p.350-362, 1996.

KRAUS, T.J.; KOEGEL, R.G.; STARUB, R.J. et al. Leachate conductivity as an index for quantifying level of forage conditioning. Saint Joseph: ASAE, 1997. 12p. (ASAE. Paper, 971100).

KUNG JUNIOR, L.; GRIEVE, D.B.; THOMAS, J.W. et al. Added ammonia or microbial inocula for fermentation and nitrogenous compounds of alfalfa ensiled at various percents of dry matter. Journal of Dairy Science, v.67, n.2, p.299-306, 1984.

LAMMERS, B.P.; BUCKMASTER, D.R.; HEINRICHS, A.J. A simple method for the analysis of particle sizes of forage and total mixed rations. Journal of Dairy Science, v.79, n.10, p.922-928, 1996.

LANGER, R.H.M. A study of growth in swards of timothy and meadow fescue. II. The effect of cutting treatments. Journal of Agricultural Science, v.52, n.3, p.273-281, 1959. 
LAVEZZO, W. Silagem de capim elefante. Informe Agropecuário, v.11, p.132, 1985.

LAVEZZO, W. Ensilagem do capim-elefante. In: SIMPÓSIO SOBRE O MANEJO DA PASTAGEM, 10., Piracicaba, 1992. Anais. Piracicaba: FEALQ, 1992. p.169-275.

LAVEZZO, W.; SILVEIRA, A.C.; GONÇALEZ, D.A. et al. Efeito da idade da planta ao primeiro corte sobre a produção, composição bromatológica e alguns aspectos morfológicos de Brachiaria decumbens, Stapf. Revista da Sociedade Brasileira de Zootecnia, v.9, n.4, p.656-672, 1980.

LEITÃO, M.F.F. Atividade de água e alterações microbiológicas dos alimentos. In: JARDIM, D.C.P.; GERMER, S.P.M. (Ed.). Atividade de água em alimentos. Campinas: ITAL, 1997. cap.3, p.1-18.

LEMAIRE, G.; CHAPMAN, D. Tissue flows in grazed plant communities. In: HODGSON, J.; ILLIUS, A.W. The ecology and management of grazing systems. New York: CAB International, 1996. p.3-36.

LIMA, C.R.; ARAÚJO, M.R.; SOUTO, S.M. Valores nutritivos da silagem de sorgo forrageiro e capins elefante, colonião, pangola e guatemala. Pesquisa Agropecuária Brasileira, v.7, n., p.53-57, 1972.

LOGAN, V.; LISTER, E.E. Grass silage for ruminants. Toronto: Minister of Supply and Service, 1979. 15p. 
LOURES, D.R.S. Características do efluente e composição químicobromatológica da silagem sob níveis de compactação e de umidade do capim-elefante (Pennisetum purpureum Schum.), cv. Cameroon. Viçosa, 2000. 67p. Dissertação (Mestrado) - Universidade Federal de Viçosa.

LUDLOW, M.M. Light relations in pasture. In: WILSON, J.R. (Ed.). Plant relations in pasture. Melbourne: CSIRO, 1978. p.35-49.

MACHADO, R.C.R.; MORENO, M.A.; ALVIM, P.T. Produtividade dos capins carimágua e colonião durante dois ciclos de crescimento. Revista Theobroma, v.14, n.3, p.229-240, 1984.

MANNO, M.C.; PEREIRA, O.G.; MARTINS, F.H. et al. Composição bromatológica de silagens de capim coastcross, com e sem inoculante microbiano (compact disc). In: REUNIÃO ANUAL DA SOCIEDADE BRASILEIRA DE ZOOTECNIA, 39., Recife. Anais. Recife: SBZ, 2002.

McCULLOUGH, M.E. Silage and silage fermentation. Feedstuffs, v.49, n.13, p.49-52, 1977.

McDONALD, P.J.; HENDERSON, A.R.; HERON, S.J.E. The biochemistry of silage. 2.ed. Mallow: Chalcombe Publications, 1991. 340p.

MERTENS, D.R. Regulation of forage intake. In: FAHEY JUNIOR, G.C.; COLLINS, M.; MERTENS, D.R. et al. (Ed.). Forage quality, evaluation and utilization. Madison: ASA; SSSA, 1994. p.450-453. 
MILFORD, R.; HAYDOCK, K.P. The nutritive value of protein in subtropical pasture species grown in southeast Queensland. Australian Journal of Experimental Agriculture and Animal Husbandry, v.5, n.1, p.13-17, 1965.

MINSON, D.J. Forage in ruminant nutrition. London: Academic Press, 1990. $483 p$.

MOTT, G.O. Evaluación de la producción de forrajes. In: HUGES, H.D.; HEATH, M.E.; METCALFE, D.S. (Ed.). Forrajes: la ciencia de la agricultura basada en la producción de pastos. México: Continental, 1970. p.131-141.

MOURA, M.P.; WERNER, J.C.; MONTEIRO, F.A. et al. Velocidade de fenação, relação lâmina-haste e teores de proteína nas lâminas e hastes de algumas leguminosas tropicais perenes e no capim-gordura. Boletim da Indústria Animal, v.32, n.2, p.363-370, 1975.

NARCISO SOBRINHO, J. Silagem de capim-elefante (Pennisetum purpureum Schum.) em três estádios de maturidade, submetido ao emurchecimento. Piracicaba, 1998. 105p. Dissertação (Mestrado) - Escola Superior de Agricultura "Luiz de Queiroz", Universidade de São Paulo.

NARCISO SOBRINHO, J.; MATTOS, H.B.; ANDRADE, J.B. et al. Silagem de capim-elefante, em três estádios de maturidade, submetido ao emurchecimento. I - Produção e composição das forragens. Boletim da Indústria Animal, v.55, n.2, p.99-111, 1998a. 
NARCISO SOBRINHO, J.; MATTOS, H.B.; ANDRADE, J.B. et al. Silagem de capim-elefante, em três estádios de maturidade, submetido ao emurchecimento. II - Qualidade das silagens. Boletim da Indústria Animal, v.55, n.2, p.113-125, 1998b.

NASCIMENTO JÚNIOR, D.; PINHEIRO, J.S. Valor nutritivo do capim-jaraguá em diferentes idades. Revista da Sociedade Brasileira de Zootecnia, v.4, n.1, p.101-113, 1975.

NUNES, S.G.; BOOCK, A.; PENTEADO, M.I.O. et al. Brachiaria brizantha cv. Marandu. 2.ed. Campo Grande: EMBRAPA, CNPGC, 1985. 31p. (EMBRAPA. CNPGC. Documentos, 21).

NUSSIO, L.G.; MANZANO, R.P.; PEDREIRA, C.G.S. Valor alimentício em plantas do gênero Cynodon. In: SIMPÓSIO SOBRE MANEJO DE PASTAGENS, 15., Piracicaba, 1998. Anais. Piracicaba: FEALQ, 1998. p. 203-242.

NUSSIO, L.G.; PAZIANI, S.F.; NUSSIO, C.M.B. Ensilagem de capins tropicais. In: BATISTA, A.M.V.; BARBOSA, S.B.P.; SANTOS, M.V.F. et al. (Ed.). A produção animal e a sociedade brasileira. Recife: SBZ, 2002. p.60-99.

NUSSIO, L.G.; MANZANO, R.P.; AGUIAR, R.N.S. et al. Silagem do excedente de produção das pastagens para suplementação na seca. In: SIMPÓSIO SOBRE MANEJO E NUTRIÇÃO DE GADO DE CORTE, Goiânia, 2000. Anais. Goiânia: CBNA, 2000. p.121-138. 
O'DONNELL, C.O.; WILLIAMS, A.G.; BIDDLESTONE, A.J. The effect of pressure and stage of ensilage on the mechanical properties and effluent production potential of grass silage. Grass and Forage Science, v.52, p.12-56, 1997.

OMALIKO, C.P.E. Influence of initial cutting date and cutting frequency on yield and quality of star, elephant and guinea grass. Grass and Forage Science, v.35, n.1, p.139-145, 1980.

OUDE ELFERINK, S.J.W.H.; DRIEHUIS, F.; GOTTSCHAL, J.C. et al. Silage fermentation processes and their manipulation. In: FAO ELETRONIC CONFERENCE ON TROPICAL SILAGE, Rome, 1999. Silage making in the tropics with emphasis on smallholders; proceedings. Rome: FAO, 2000. p.17-30.

PAULY, T.M. Heterogeneity and hygienic quality of grass silage. Uppsala, 1999. 157p. Thesis (Doctoral) - Swedish University of Agricultural Sciences.

PAZIANI, S.F.; NUSSIO, L.G.; LOURES, D.R.S. et al. Effects of particle size, microbial additive and moisture of Tanzania grass silage (Panicum maximum cv. Tanzania) on beef heifers' performance. In: WORLD CONFERENCE ON ANIMAL PRODUCTION, 9., Porto Alegre, 2003. |No prelo|.

PEDREIRA, J.V.S.; SILVEIRA. J.J.N. Variação da composição bromatológica do capim-colonião Panicum maximum Jacq. In: REUNIÃO ANUAL DA SOCIEDADE BRASILEIRA DE ZOOTECNIA, 8., Rio de Janeiro, 1971. Anais. Rio de Janeiro: SBZ, 1971. p.5-6. 
PINTO, J.C.; GOMIDE, J.A.; MAESTRI, M. Produção de matéria seca e relação folha:caule de gramíneas forrageiras tropicais, cultivadas em vasos, com duas doses de nitrogênio. Revista da Sociedade Brasileira de Zootecnia, v.23, n.3, p.313-326, 1994.

PRÓSPERO, A.O. Variação estacional da composição químico-bromatológica, do teor de macronutrientes minerais e da digestibilidade "in vitro" do capim elefante (Pennisetum purpureum, Schum) variedade Napier. Anais da Escola Superior de Agricultura "Luiz de Queiroz", v.29, p.81-93, 1972.

REIS, R.A.; COAN, R.M. Produção e utilização de silagens de gramíneas. In: SIMPÓSIO GOIANO SOBRE MANEJO E NUTRIÇÃO DE BOVINOS, 3., Goiânia, 2001. Anais. Goiânia: CBNA, 2001. p.91-120.

REIS, R.A.; JOBIM, C.C. Perfil da fração de carboidratos da planta e adequação de aditivos no processo de ensilagem. In: WORKSHOP SOBRE MILHO PARA ENSILAGEM, 2., Piracicaba, 2000. Anais. Piracicaba: FEALQ, 2001. p.27-51.

REIS, R.A.; RODRIGUES, L.R.A. Valor nutritivo de plantas forrageiras. Jaboticabal: Funep, 1993. 26p.

RENVOIZE, S.A.; CLAYTON, W.D.; KABUYE, C.H.S. Morphology, taxonomy and natural distribution of Brachiaria (Trin.) Griseb. In: MILES, J.W.; MASS, B.L.; VALLE, C.B. (Ed.). Brachiaria: biology, agronomy and improvement. Cali: CIAT; Campo Grande: EMBRAPA, CNPGC, 1996. cap.1, p.1-15.

REYNOLDS, A.M.; WILLIAMS, A.G. A model of silage consolidation and effluent flow. Journal of Agricultural Engineering Research, v.61, p.173182, 1995. 
RIBEIRO, K.G.; GOMIDE, J.A.; PACCIULLO, D.S.C. Adubação nitrogenada do capim Elefante cv. MOTT. 2 - Valor nutritivo ao atingir 80 e $120 \mathrm{~cm}$ de altura. Revista Brasileira de Zootecnia, v.28, n.6, p.1194-1202, 1999.

RIBEIRO, K.G.; PEREIRA, O.G; SOUZA, P.P.O. de et al. Composição bromatológica de silagens de Brachiaria decumbens, tratadas com inoculante microbiano em diferentes idades de corte (compact disc). In: REUNIÃO ANUAL DA SOCIEDADE BRASILEIRA DE ZOOTECNIA, 39., Recife. Anais. Recife: SBZ, 2002.

ROCHA, G.P. Efeito da idade na composição química, digestibilidade in vitro e taxa de fermentação de oito gramíneas tropicais. Lavras, 1979. 104p. Dissertação (Mestrado) - Escola Superior de Agricultura de Lavras.

RODRIGUES, C.S.; BLANCO, E. Composición química de hojas y tallos de 21 cultivares de elefante (Pennisetum purpureum, Schum.). Agronomia Tropical, v.20, n.6, p.383-396, 1970.

ROLIM, F.A. Efeito da maturidade sobre a produção e o valor nutritivo dos capins Braquiária (Brachiaria decumbens, Stapf), Estrela [Cynodon plectostachyus, (K. Schum) Pilger] e Rhodes (Chloris gayana, Kunth cultivar Callide). Piracicaba, 1976. 117p. Dissertação (Mestrado) - Escola Superior de Agricultura "Luiz de Queiroz", Universidade de São Paulo.

RUGGIERI, A.C.; FAVORETTO, V.; MALHEIROS, E.B. Características de crescimento e produção de matéria seca da Brachiaria brizantha (Hochst) Stapf. cv. Marandu em função de níveis de nitrogênio e regime de cortes. Boletim da Indústria Animal, v.51, n.2, p.149-155, 1994. 
RUGGIERI, A.C.; FAVORETTO, V.; MALHEIROS, E.B. Efeito de níveis de nitrogênio e regimes de corte na distribuição, na composição bromatológica e na digestibilidade "in vitro" da matéria seca da Brachiaria brizantha (Hochst) Stapf. cv. Marandu. Revista da Sociedade Brasileira de Zootecnia, v.24, n.1, p.21-30, 1995.

SANTANA, J.R.; SANTOS, C.L.. Efeito do parcelamento de nitrogênio e intervalos entre cortes sobre a produção de matéria seca e de proteína bruta de Setaria anceps (Schum.) Stapf. \& Hub. cv. Kazungula. Revista da Sociedade Brasileira de Zootecnia, v.12, n.3, p.522-534, 1983.

SANTANA, J.R.; PEREIRA, J.M.; ARRUDA, N.G. et al. Avaliação de cultivares de capim elefante (Pennisetum purpureum, Schum.) no sul da Bahia. I Agrossitema cacaueiro. Revista da Sociedade Brasileira de Zootecnia, v.18, n.3, p.273-283, 1989.

SANTOS, P.M. Estudo de algumas características agronômicas de Panicum maximum (Jacq.) cvs. Tanzânia e Mombaça para estabelecer seu manejo. Piracicaba, 1997. 62p. Dissertação (Mestrado) - Escola Superior de Agricultura "Luiz de Queiroz", Universidade de São Paulo.

SANTOS, P.M.; CORSI, M.; BALSALOBRE, M.A.A. Efeito da freqüência de pastejo e da época do ano sobre a produção e qualidade em Panicum maximum cv.s. Tanzânia e Mombaça. Revista Brasileira de Zootecnia, v.28, n.2, p.244-249, 1999.

SAS INSTITUTE. The SAS system for Windows: version 6.12 (compact disc). Cary, SAS Institute, 1996. 
SHENK, J.S.; WESTERHAUS, M.O. Population definition, sample selection, and calibration procedures for near infrared reflectance spectroscopy. Crop Science, v.31, p.469-474, 1991.

SILVEIRA, A.C.; FARIA, V.P.; TOSI, H. Efeito da maturidade sobre o valor nutritivo do capim Napier. O Solo, v.65, n.2, p.35-41, 1973a.

SILVEIRA, A.C.; TOSI, H.; FARIA, V.P. et al. Efeito de diferentes tratamentos na digestibilidade in vitro de silagens de capim-elefante (Pennisetum purpureum, Schum.). Revista da Sociedade Brasileira de Zootecnia, v.2, n.2, p.216-226, 1973b.

SILVEIRA, A.C.; TOSI, H.; FARIA, V.P. et al. Efeito da maturidade sobre a composição químico-bromatológica do capim Napier (Pennisetum purpureum, Schum.). Revista da Sociedade Brasileira de Zootecnia, v.3, n.2, p.158-171, 1974.

SINGH, D.K. Effect of cutting management on yield and quality of different selections of guinea grass (Panicum maximum (Jacq.) L.) in a humid subtropical environment. Tropical Agriculture, v.72, n.3, p.181-187, 1995.

SKERMAN, P.J.; RIVEROS, F. Brachiaria. In: FAO. Tropical grasses. Rome, 1990. p.234-262.

VALLE, C.B.; EUCLIDES, V.P.B.; MACEDO, M.C.M. Características das plantas forrageiras do gênero Brachiaria. In: SIMPÓSIO SOBRE MANEJO DAS PASTAGENS, 17., Piracicaba, 2000. Anais. Piracicaba: FEALQ, 2000. p.65-108. 
VAN SOEST, P.J. Nutritional ecology of ruminant. 2.ed. New York: Cornell University Press, 1994. 476p.

VAN SOEST, P.J.; ROBERTSON, J.B.; LEWIS, B. Methods for dietary fiber, neutral detergent fiber, and non-starch polysaccharides in relation to animal nutrition. Journal of Dairy Science, v.74, p.3583-3597, 1991.

VIANA, O.J.; GADELHA, J.A.; ALBUQUERQUE, J.J.L. et al. Curva de crescimento e valor protéico do capim-elefante, cultivar mineiro, no Ceará. Boletim Cearense de Agronomia, v.17, p.35-46, 1976.

VICENT-CHANDLER, J.; SILVA, S.; FIGARELLA, J. The effect of nitrogen fertilization and frequency of cutting on the yield and composition of three tropical grasses. Agronomy Journal, v.51, n.4, p.202-206, 1959.

VIEIRA, A.C. Efeito da idade de corte sobre a produção, composição químicobromatológica, digestibilidade in vitro e teor de ácido cianídrico de Cynodon dactylon (L.) Pers. cv. Florakirk. Piracicaba, 1998. 103p. Dissertação (Mestrado) - Escola Superior de Agricultura "Luiz de Queiroz", Universidade de São Paulo.

VIEIRA, L.M.; GOMIDE, J.A. Composição química e produção forrageira de três variedades de capim-elefante. Ceres, v.10, n.4, p.71-91, 1970.

VILELA, H.; GOMIDE, J.A.; MAESTRI, M. Efeito da idade da planta ao primeiro corte e dos intervalos entre cortes sobre o rendimento forrageiro, teor de carboidratos solúveis na base da planta, índice de área foliar e interceptação de luz em aveia forrageira (Avena bizantina L.). Revista da Sociedade Brasileira de Zootecnia; v.7, n.1, p.79-93, 1978. 
VILELA, H; BARBOSA, F.A.; TEIXEIRA, E.A. et al. Efeito da idade da planta sobre a produção e valor nutritivo de forragem do capim Elefante Paraíso (Pennisetum hybridum). In: REUNIÃO ANUAL DA SOCIEDADE BRASILEIRA DE ZOOTECNIA, 38., Piracicaba, 2001. Anais. Piracicaba: FEALQ, 2001. p.320-321.

VILELA, H; NOGUEIRA, A.C.; TEIXEIRA, E.A. et al. Produção de forragem do capim Elefante Paraíso-híbrido hexaplóide e seu valor nutritivo. In: REUNIÃO ANUAL DA SOCIEDADE BRASILEIRA DE ZOOTECNIA, 35., Botucatu, 1998. Anais. Botucatu: SBZ, 1998. p.615-616.

WARD, C.Y.; BLASER, R.E. Carbohydrate food reserves and leaf area in regrowth rate in orchard grass. Crop Science, v.1, n.5, p.366-370, 1961.

WEBSTER, R. D. Genera of the North American Paniceae (Poaceae: Panicoideae). Systematic Botany, v.13, p. 576-609,1988.

WEISSBACH, F.; SCHMIDT, L.; HEIN, E. Method of anticipation of the run of fermentation in silage making, based on the chemical composition of green fodder. In: INTERNATIONAL GRASSLAND CONGRESS, 12., Moscow, 1974. Proceedings. Moscow: Akademic Press, 1974. p.663-673.

WIERINGA, G.W. The influence of nitrate on silage fermentation. In: INTERNATIONAL GRASSLAND CONGRESS, 10., Helsinki, 1966. Proceedings. Helsinki: The Finnish Grassland Association, 1966. p.537540.

WILES, P.G.; GRAY, I.K.; KISSLING, R.C. Routine analysis of protein by Kjeldahl and Dumas methods: review and interlaboratory study using dairy products. Journal of AOAC International, v.81, n.3, p.620-632, 1998. 
WILKINS, R.J.; SYRJÃLÃ, L.; BOLSEN, K.K. The future of silage in sustainable animal production. In: INTERNATIONAL SILAGE CONFERENCE, 12. Uppsala, 1999. Proceedings. Uppsala: Swedish University of Agricultural Sciences, 1999. p.23-40.

WILSON, J.R. Environmental and nutritional factors affecting herbage quality. In: HACKER, J.B. (Ed.). Nutritional limits to animal production from pastures. Farnham Royal: CAB, 1982. p.111-131.

WILSON, J.R.; MINSON, D.J. Prospects for improving the digestibility and intake of tropical grasses. Tropical Grasslands, v.14, n.3, p.253-259, 1980.

WILSON, J.R.; 't MANNETJE, L. Senescence, digestibility and carbohydrate content of buffel grass and green panic leaves in swards. Australian Journal of Agricultural Research, v.29, n.3, p.503-516, 1978.

WILSON, J.R.; JONES, R.N.; MINSON, O.J. Influence of temperature on the digestibility and growth of Macroptilium atropurpureum and Panicum maximum var. Trichoglume in subtropical Australian. Tropical Grasslands, v.20, n.4, p.145-155, 1986.

WOOLFORD, M.K. The silage fermentation. New York: Marcel Dekker, 1984. $350 p$.

WOOLFORD, M.K. Some aspects of the microbiology and biochemistry of silage making. Herbage Abstracts, v.42, p.105-111, 1972. 
ZAGO, C.P.; GOMIDE, J.A. Valor nutritivo do capim-colonião, submetido a diferentes intervalo de corte, com e sem adubação de reposição. Revista da Sociedade Brasileira de Zootecnia, v.11, n.3, p.512-528, 1982. 